\author{
UNIVERSIDADE DE SÃO PAULO \\ ESCOLA DE ARTES, CIÊNCIAS E HUMANIDADES \\ PROGRAMA DE PÓS-GRADUAÇÃO EM SUSTENTABILIDADE
}

VANIA RODRIGUES LOPES

Avaliação da atividade estrogênica em esgotos sanitários e águas de reúso na região metropolitana

de São Paulo

São Paulo

2016 


\title{
Avaliação da atividade estrogênica em esgotos sanitários e águas de reúso na região metropolitana de São Paulo
}

Versão corrigida

Dissertação apresentada à Escola de Artes, Ciências e Humanidades da Universidade de São Paulo para obtenção do título de Mestre em Ciências pelo Programa de Pós-graduação em Sustentabilidade.

\begin{abstract}
Área de concentração:
Ciência e Tecnologia Ambiental

Versão corrigida contendo as alterações solicitadas pela comissão julgadora em 03 de dezembro de 2015. A versão original encontra-se em acervo reservado na Biblioteca da EACH-USP e na Biblioteca Digital de Teses e Dissertações da USP (BDTD), de acordo com a Resolução CoPGr 6018, de 13 de outubro de 2011.
\end{abstract}

Orientador:

Prof. Dr. Marcelo Antunes Nolasco

São Paulo

2016 
Autorizo a reprodução e divulgação total ou parcial deste trabalho, por qualquer meio convencional ou eletrônico, para fins de estudo e pesquisa, desde que citada a fonte.

CATALOGAÇÃO-NA-PUBLICAÇÃO

(Universidade de São Paulo. Escola de Artes, Ciências e Humanidades. Biblioteca)

Lopes, Vania Rodrigues

Avaliação da atividade estrogênica em esgotos sanitários e águas de reúso na região metropolitana de São Paulo / Vania

Rodrigues Lopes ; orientador, Marcelo Antunes Nolasco. - São

Paulo, 2016

$100 \mathrm{f}$. : il

Dissertação (Mestrado em Ciências) - Programa de PósGraduação em Sustentabilidade, Escola de Artes, Ciências e Humanidades, Universidade de São Paulo

Versão corrigida

1. Efluentes. 2. Tratamento de águas residuárias. 3.

Fármacos. 4. Sustentabilidade. 5. Estrógenos. I. Nolasco, Marcelo Antunes, orient. II. Título

CDD 22.ed. -363.7284 
Nome: LOPES, Vania Rodrigues

Titulo: Avaliação da atividade estrogênica em esgotos sanitários e águas de reúso na região metropolitana de São Paulo

Dissertação apresentada à Escola de Artes, Ciências e Humanidades da Universidade de São Paulo para obtenção do título de Mestre em Ciências do Programa de Pós-Graduação em Sustentabilidade

Área de concentração:

Ciência e Tecnologia Ambiental

Aprovado em:

Banca Examinadora

Prof. Dr. Instituição:

Julgamento: Assinatura:

Prof. Dr. Instituição:

Julgamento: Assinatura:

Prof. Dr. Instituição:

Julgamento: Assinatura: 


\section{Agradecimentos}

À Deus por prover força e fé.

Ao meu orientador Prof. Marcelo Nolasco pelo esforço em contribuir no meu desenvolvimento acadêmico, por propiciar condições, por incentivar minhas realizações e por apresentar novas perspectivas.

Ao Roberto Ortiz pelo companheirismo, apoio emocional e intelectual.

À minha mãe pela incansável paciência e à minha família pelo carinho e atenção.

À Maria Inês Sato por todo suporte e inspiração para concretização deste trabalho.

Ao Gilson Quináglia por disponibilizar a infraestrutura e apoio técnico de laboratório para realização do trabalho e pela confiança depositada.

À Daniela Dayrell que não mediu esforços em me treinar e compartilhar conhecimentos para compreensão do bioensaio.

À equipe técnica da Cetesb: Wálace Soares, Ivo Oliveira, Rubia Kuno, Genival de Oliveira, Gisela Martini, Bárbara Held, Francisco Viana, Carlos Coimbrão, Ana Galvani, Paulo Rodrigues e todos queridos amigos pela colaboração e apoio.

À equipe de coleta da Cetesb: Carlos Brandão, Vivian Baltazar, Paulo Rocha por viabilizarem a programação de amostragem em suas agendas trabalho de campo.

À SABESP principalmente ao Flávio Machado, Marcelo Miki e gerentes das ETEs por concederem as amostras e informações.

Aos queridos amigos do laboratório LabSan-USP e Grupo de Pesquisa Gepass aos quais devo minha imensa gratidão por sempre apoiarem, vivenciarem junto e compartilharem suas experiências, Helisson, Neildes, Vitor, Grace, Alexandre, Juliana, Dayana, Camila, Leandro, Gabriel, Gabriela, João, Mariana, e todos demais bolsistas que estiveram no grupo.

Aos amigos pós-graduandos do programa de Sustentabilidade da EACH-USP pela amizade, em especial ao amigo Francisco Daniel pelo compromisso em me apoiar e por se fazer sempre presente.

Aos professores do programa de pós-graduação em sustentabilidade da EACH-USP, em especial a professora Helene Ueno que desde o início apoiou e prestou generoso auxílio e às professoras Delhi Salinas e Renata Colombo pelo suporte educativo.

Aos membros da banca de qualificação Profa Wânia Duleba e Prof. Gilson Quináglia pelas sugestões e recomendações para o trabalho. 
Ao CNPq e projeto FINEP-RENTED pela concessão de bolsa que possibilitou a realização deste trabalho.

Ao Programa EXCEED e seus membros pela concessão de bolsa de intercâmbio na UNAM, bem como aos professores e amigos da UNAM-IINGEN pela dedicação e cordialidade durante o desempenho das minhas atividades acadêmicas.

Às amigas Lourdinha, Fátima e Verônica que me incentivaram na busca de novos horizontes.

A todos meus amigos e familiares que compreenderem meu distanciamento temporário. 


\section{Resumo}

LOPES, V. R. Avaliação da atividade estrogênica em esgotos sanitários e águas de reúso na região metropolitana de São Paulo. 2016. 100 f. Dissertação (Mestrado em ciências) Escola de Artes, Ciências e Humanidades, Universidade de São Paulo, São Paulo, 2016.

Os esgotos sanitários concentram compostos que são interferentes endócrinos. Os tratamentos de esgotos convencionais por sistema de lodos ativados podem não remover totalmente estes compostos, os quais atingem os ecossistemas aquáticos e oferecem riscos ecológicos e à saúde humana. Neste trabalho, mediu-se a atividade estrogênica de compostos presentes em esgotos brutos, tratados e águas de reúso de duas estações de tratamento de esgotos (ETE) da região metropolitana de São Paulo, que operam por sistema de tratamento por lodos ativados e produzem águas de reúso para fins não potáveis por tratamento físico-químico. Nesse procedimento, as amostras foram preparadas por extração de fase sólida e utilizou-se o bioensaio BLYES (Bioluminescence Yeast Estrogen Screen) para a quantificação de efeito de atividade estrogênica em nanogramas de 17ß-estradiol equivalente (ng-EEQ/L). A estrogenicidade da amostra foi calculada por meio da EC50 (concentração efetiva em 50\%), para isto foram utilizadas diluições seriadas para curva padrão com $17 \beta$-estradiol e para cada amostra analisada. A toxicidade nos ensaios foi medida e monitorada pela levedura controle BLYR. A atividade estrogênica no esgoto bruto variou de 14,7 a 52,6 ng-EEQ/L. Os resultados em esgotos tratados por sistema de lodos ativados variaram de abaixo o limite de quantificação do bioensaio de $<0,10$ ng-EEQ/L a 11ng-EEQ/L, indicando eficiência de remoção entre $50 \%$ a $100 \%$. As águas de reúso foram produzidas por filtração e cloração e na maioria dos resultados apresentaram atividade estrogênica de $<0,10$ ng-EEQ/L. Os resultados obtidos neste estudo foram comparáveis aos encontrados na literatura medidos pelo bioensaio YES. Os resultados demonstraram que o bioensaio BLYES foi viável para quantificar a estrogenicidade em todas as amostras testadas. As evidências acerca da atividade estrogênica das águas estudadas podem subsidiar ações integradas na gestão da qualidade das águas, o aprimoramento de condições operacionais e tecnológicas das ETEs.

Palavras-chave: Recursos hídricos. Estações de tratamento de esgoto. Interferentes endócrinos. Estrogenicidade. BLYES. 


\begin{abstract}
LOPES, Vania. Rodrigues. Evaluation of estrogenic activity on sanitary wastewater and reclaimed reclaimed water of São Paulo metropolitan region. 2016. $100 \mathrm{f}$. Dissertation (Master of Science) - Escola de Artes, Ciências e Humanidades, Universidade de São Paulo, São Paulo, 2016.

The wastewater concentrates compounds with endocrine disruptors. The conventional wastewater treatment by activated sludge are not able to completely remove these compounds, whose achieve aquatic ecosystems and offer ecologic risks and to human health. In this study we measured estrogenic activity on raw and treated wastewater and reclaimed water from two wastewater treatment plants (WWTPs) in the metropolitan region of São Paulo. These WWTPs treat wastewater by activated sludge process and produce reclaimed water for non potable purposes by physical chemical processes. By this procedure, the samples were collected on both WWTPs before and after described treatments and they were prepared by solid phase extraction (SPE). The samples after SPE were analyzed by the BLYES (Bioluminescence Yeast Estrogen Screen) bioassay for quantifying estrogenic activity measured by nanograms $17 \beta$-estradiol equivalent per litre (ng-EEQ/L). The estrogenicity of sample was calculated by EC50 (half maximal effective concentration), for that were applied serial dilutions to $17 \beta$-estradiol standard curve and for each sample. They were implemented serial dilutions for monitoring sample's toxicity by BLYR yeast control. The estrogenic activity on raw wastewater ranged by 14,7 to $52,6 \mathrm{ng}-\mathrm{EEQ} / \mathrm{L}$. The treated wastewater by activated sludge presented results below the quantification of assay limit of $<0,10 \mathrm{ng}-\mathrm{EEQ} / \mathrm{L}$ to $11 \mathrm{ng}-\mathrm{EEQ} / \mathrm{L}$, indicating removal efficiency between $50 \%$ to $100 \%$. The reclaimed water was produced by chlorination and filtration and presented results of estrogenic activity of < $0,10 \mathrm{ng}-\mathrm{EEQ} / \mathrm{L}$ on majority analyzed samples. The results showed that BLYES bioassay was viable to quantify estrogenicity in all tested samples. The evidences on estrogenic activity in studied waters may offer subsidies for integrated actions on water quality management, improvements on operational conditions and technologies of WWTPs.
\end{abstract}

Keywords: Water resources. Wastewater treatment plant. Endocrine disruptors. Estrogenicity. BLYES. 


\section{Lista de figuras}

Figura 1 - Esquemas representativos da estrutura química de hormônios. ............................. 20

Figura 2 - Representação de estruturas químicas variadas de interferentes endócrinos. ......... 21

Figura 3 - Curva monotônica do efeito da genisteína no aumento de peso uterino em ratas...23

Figura 4 - Representação esquemática de fontes pontuais e difusas de interferentes endócrinos, processos físicos e biológicos em meio aquático 26

Figura 5 - Relação entre os mecanismos de sorção e biodegradação na remoção de estrógenos. 333

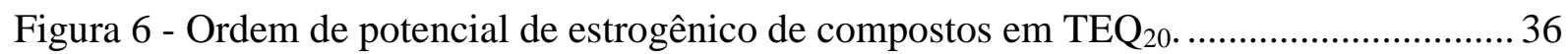

Figura 7 - Etapas dos processos de tratamento por sistema de lodos ativados da ETE 1..... 466

Figura 8 - Intensidades de chuvas mensais e anuais no Estado de São Paulo em 2014...........47

Figura 9 - Tratamentos por filtração e desinfecção nas ETEs 1 e 2 para produção de águas de reúso. 48

Figura 10 - Representação de microplaca modelo Elisa com modelo de marcação de diluições e controles utilizados para realizar o ensaio.

Figura 11 - Curva sigmoidal com padrão de 17ß-estradiol com levedura Saccharomyces cerevisiae no ensaio BLYES $(\mathrm{n}=18)$.

Figura 12 - Resultados de eficiência de remoção de estrogenicidade na ETE-1 e ETE-2, expressos em ng-EEQ/L, quantificado por BLYES.

Figura 13 - Resultado de 14,7 ng-EEQ/L de atividade estrogênica de amostra de esgoto bruto da ETE 1, no ensaio I.

Figura 14 - Resultado de atividade estrogênica de 24,4 ng-EEQ/L da amostra de esgoto bruto da ETE 2, ensaio I . .76

Figura 15 - Resultado de atividade estrogênica de 0,31 ng-EEQ/L da amostra de esgoto tratado na ETE 1, do ensaio II 


\section{Lista de quadros}

Quadro - Classificação de interferentes endócrinos agrupados e exemplificados em

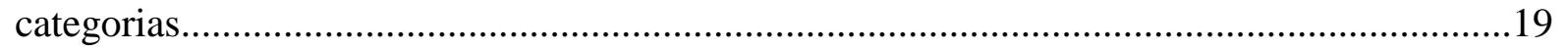

\section{Lista de tabelas}

Tabela 1 - Compostos estrogênicos e concentrações máximas admissíveis propostas pela Comissão Europeia para inclusão na lista de compostos prioritários para regulamentação.

Tabela 2 -Estudos nacionais de ocorrência de hormônios naturais e sintéticos em diferentes matrizes ambientais

Tabela 3 - Soluções para preparo de meio mínimo de cultura para crescimento de levedura . 55

Tabela 4 - Diluições do padrão $17 \beta$-estradiol 58

Tabela 5 - Resultados de atividade estrogênica em esgoto bruto da ETE-1 e ETE-2, expressos em ng-EEQ/L quantificados por BLYES ..62

Tabela 6 - Resultados de atividade estrogênica de esgotos tratados das ETE-1 e ETE-2, expressos em ng-EEQ/L quantificado por BLYES. . .66 


\section{Lista de abreviaturas e siglas}

BLYES Bioluminescent Yeast Estrogen Screen

BLYR Bioluminescent Yeast Constitutive Bioreporter

CETESB Companhia Ambiental do Estado de São Paulo

CGCRE Coordenação Geral de Acreditação do Inmetro

DDT Diclorodifeniltricloroetano

DDE Diclorodifenildicloroetileno

DMSO Dimetilsulfóxido

DO Densidade óptica

E1 Estrona

E2 17 1 -estradiol

E3 Estriol

EC-10 Concentração efetiva que causa efeito biológico a $10 \%$ dos organismos

EC-20 Concentração efetiva que causa efeito biológico a $20 \%$ dos organismos

EC-50 Metade da concentração máxima efetiva

EE2 $17 \alpha$-etinilestradiol

ER Receptor de estrógeno

ER- $\alpha \quad$ Receptor de estrógeno alfa

ER- $\beta \quad$ Receptor de estrógeno beta

ERE Elemento respondedor a estrógeno

ETE Estação de Tratamento de Esgotos

HBCDD Hexabromociclododecano

HCB Hexaclorobenzeno

hER- $\alpha \quad$ Receptor humano de estrógeno alfa

HLB Balanço hidro-lipofílico

ICCVAM Interagency Coordination Committee on the Validation of Alternative Methods

ICTEM Índice de Controle e Tratabilidade de Esgoto do Município

IE Interferente endócrino

IQA Índice de qualidade das águas

ISO Organização Internacional para Padronização

IVA Índice de Qualidade da Água para Proteção da Vida 
LOW BP Low Balance Polarity.

LUC/LUX Luciferase

MMA Ministério do Meio Ambiente

NIEHS National Institute of Environmental Health Sciences

OMS Organização Mundial da Saúde

PBB Bifenilapolibromadas

PBDE Éter difenilpolibromado

PCB bifenilapolicloradas

PCDDs dibenzodioxinaspolicloradas

PCDF dibenzofuranospoliclorados

PFOA Ácido perfluorooctanóico

PFOS Ácido perfluorooctanossulfônico

POP Poluente orgânico persistente

SABESP Companhia de Saneamento Básico do Estado de São Paulo

SPE Extração de fase sólida

TEQ Quociente de equivalente toxicidade

TIER Toxicity Identification Evaluation Response

TDH Tempo de detenção hidráulica

TRS Tempo de retenção sólida ou idade do lodo

UNEP Programa das Nações Unidas para o Meio Ambiente

YES Yeast Estrogen Screen 


\section{Sumário}

1. Introdução .......................................................................................................14

2. Revisão Bibliográfica...............................................................................17

2.1. Interferentes endócrinos ..........................................................................17

2.2. Ocorrência de interferentes endócrinos ......................................................25

2.3. Fatores associados à remoção de interferentes endócrinos em estações de tratamento de esgotos............................................................................................30

2.4. Riscos ecológicos associados aos interferentes endócrinos e bioensaios para análise de atividade estrogênica.....................................................................34

2.4.1. Bioensaios para estrogenicidade in vivo ....................................................38

2.4.2. Bioensaios para estrogenicidade in vitro ................................................38

2.4.3. Receptor de estrógenos (ER) por ligação competitiva ............................39

2.4.3.1. Ensaios de proliferação celular ........................................................... 39

2.4.3.2. Ensaio de gene repórter cuja ligação depende de atividade de transcrição

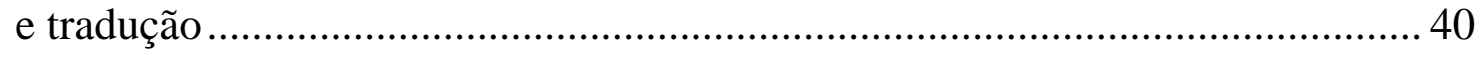

2.5. Avaliação de atividade estrogênica por técnica de BLYES ..................... 41

3. Objetivos ...................................................................................................44

3.1. Objetivo geral ...............................................................................................44

3.2. Objetivos específicos ..........................................................................................44

4. Metodologia ...................................................................................................45

4.1. Atividades de campo: amostragem e coletas nas estações de tratamento de esgotos................................................................................................................45

4.2. Ensaios laboratoriais.....................................................................................50

4.2.1. Filtração das amostras...........................................................................50

4.2.2. Etapa de extração de fase sólida - SPE....................................................51

4.2.2.1. Condicionamento de cartuchos........................................................... 52

4.2.2.2. Eluição das amostras.......................................................................... 53 
4.2.2.3. Concentração de amostras

4.2.3. Etapa do bioensaio ...................................................................................................55

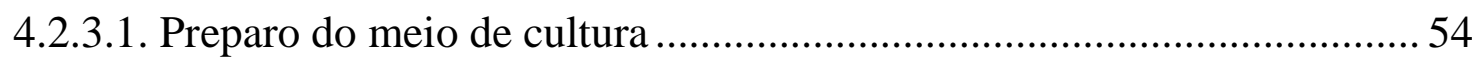

4.2.3.2. Crescimento das linhagens de Saccharomyces cerevisiae .................... 55

4.2.3.3. Diluições de padrão de $17 \beta$-estradiol e amostras ......................................56

4.2.3.4. Curva padrão................................................................................... 57

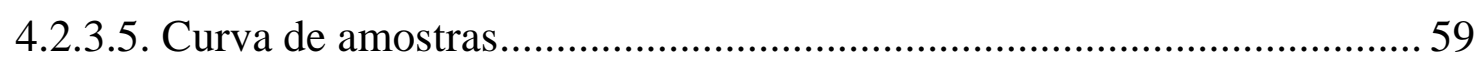

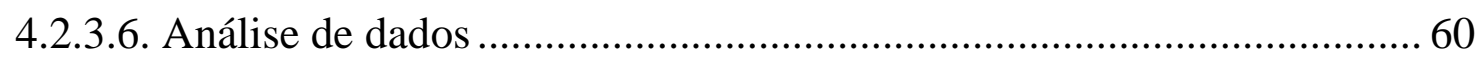

5. Resultados e discussão...............................................................61

5.1. Avaliação de atividade estrogênica nas ETEs .............................................61

5.1.1. Esgoto Bruto ...................................................................................61

5.1.2. Eficiência de remoção de atividade estrogênica das ETEs 1 e 2 nos

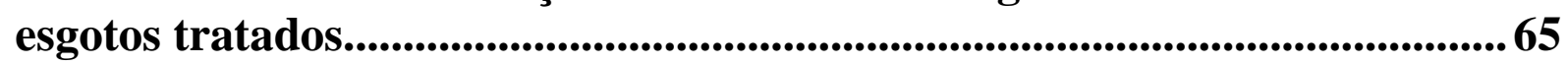

5.1.3. Fatores relacionados à eficiência de remoção de hormônios estrogênicos em ETEs .......................................................................................................69

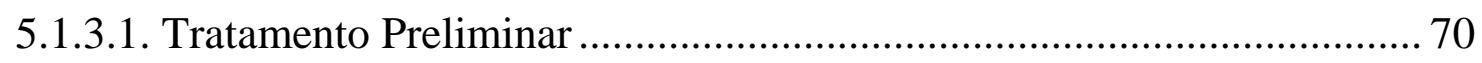

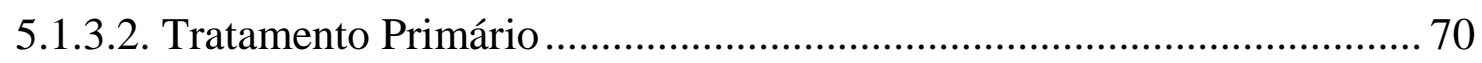

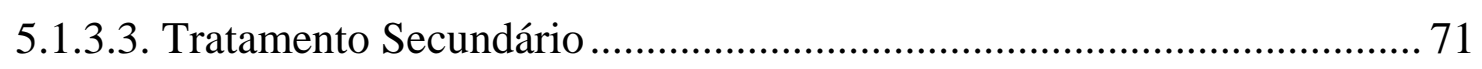

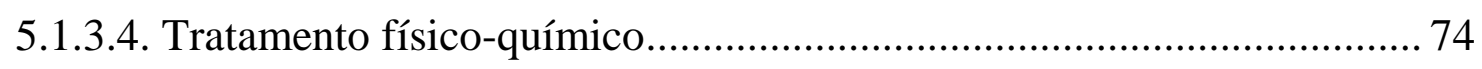

5.1.4. Avaliação do bioensaio de BLYES em esgotos brutos e tratados.......75

5.1.5. Destinação de esgotos brutos e tratados...............................................79

6. Conclusões e considerações finais ..........................................882

6.1. Sugestões para estudos futuros ............................................................................85

Referências .........................................................................................866

Apêndice .................................................................................99 


\section{Introdução}

Entre os principais desafios para se atingir a sustentabilidade do século XXI estão àqueles relacionados à qualidade e quantidade de água no planeta (UNESCO, 2009). Entre eles, podemos citar o acesso à água potável, a conservação de reservas de água, o consumo perdulário e as condições inadequadas de infraestrutura de saneamento ambiental.

Diante do crescimento populacional e econômico, as práticas agrícolas com uso de agroquímicos, a atividade industrial e o aumento nos hábitos de consumo vêm intensificando significativamente a exposição dos recursos hídricos aos poluentes de natureza física, química e biológica. Essa conjuntura requer um melhor controle da qualidade das águas seja pelo uso de técnicas analíticas específicas para detecção de compostos, bem como por medidas de monitoramento contínuo dos processos de tratamento de águas residuárias e de consumo humano (KOOKANA; WILLIAMS; WALLER, 2007; LUO et al., 2014).

Prioritariamente, parte da solução desses problemas representam a melhoria e preservação da qualidade das águas que inclui a ampliação das redes de coleta e de tratamento de águas residuárias, a regulamentação e a fiscalização do sistema de esgotamento e o aprimoramento nas tecnologias empregadas nos sistemas de tratamento de esgotos e efluentes de origem industrial. Por sua vez, as ações de planejamento e de infraestrutura sanitária podem contribuir para reduzir os riscos à saúde da população e os problemas associados à deterioração dos ecossistemas aquáticos.

Nas últimas décadas, foram notáveis os avanços na indústria química os quais permitiram o desenvolvimento de produtos para as mais diversas finalidades. Contudo, o conhecimento dos efeitos sobre os compostos sintéticos inseridos no dia a dia trazem à tona discussões sobre os riscos e impactos aos ecossistemas aquáticos e à saúde humana.

As primeiras descobertas acerca dos efeitos tóxicos dos poluentes orgânicos persistentes (POPs) publicadas na década de 1960 perduram até hoje sendo investigadas porque foram revelados novos mecanismos associados à toxicidade desses compostos e de outros de classificação semelhante. Apesar de terem sido banidos ou controlados, suas concentrações conservam-se porque se bioacumulam nos organismos.

O conhecimento sobre compostos químicos indicam que é preciso cautela no uso e disposição no meio ambiente, pois até mesmo novos de compostos, substitutos daqueles de toxicidade reconhecida, persistem oferecendo riscos biológicos. Eventualmente, os riscos são mascarados pela ausência de efeito agudo e pela indução de resposta em baixas 
concentrações. Isto porque persistem no meio ambiente uma vez que são continuamente inseridos (COLBORN; VOM SAAL; SOTO, 1993; GUILLETTE; IGUCHI, 2012).

A exposição de peixes e outros organismos aquáticos a esses poluentes, provoca alterações hormonais com efeitos adversos em seu desenvolvimento e sistemas reprodutivos (COLBORN; VOM SAAL; SOTO, 1993; FENSKE et al., 2005; METCALFE et al., 2001; PANTER, G.; THOMPSON, R.; SUMPTER, J., 1998; SOTO et al., 1991; VAN DEN BELT; VERHEYEN; WITTERS, 2003).

Devido ao sistema endócrino ser vulnerável a concentrações mínimas desses compostos, tem sido relatado na literatura especializada, disfunções que são naturalmente reguladas pelos hormônios, porém alteradas em várias espécies na presença de compostos e associadas a efeitos adversos na saúde humana. As pesquisas em endocrinologia humana sugerem que alterações no sistema endócrino podem desencadear doenças como diabetes, obesidade, síndrome metabólica e queda de fertilidade pela exposição a compostos químicos. Essas evidências remetem à necessidade de implementação de medidas que prevem o monitoramento da presença de compostos como: bisfenol A, organoclorados, ftalatos, alquilfenóis, hidrocarbonetos aromáticos policíclicos e metais pesados presentes em águas, alimentos e produtos de consumo tais como de higiene pessoal, medicamentos, entre outros (DE COSTER; VAN LAREBEKE, 2012).

Muitos poluentes, compostos sintéticos e naturais não são completamente removidos pelos sistemas de tratamentos de esgotos convencionais, como é o caso do sistema de lodos ativados, que faz uso de tratamento, predominantemente biológico para remoção de matéria orgânica. Por não serem degradados por esse tratamento, alguns poluentes se mantém inalterados ou são transformados em outros produtos que permanecem biologicamente ativos nos corpos receptores em que são lançados (AQUINO; BRANDT; CHERNICHARO, 2013; ESPERANZA et al., 2004; LUO et al., 2014; LUST et al., 2015; TERNES et al., 1999a).

Os dados de publicações nacionais são de identificação e quantificação dos poluentes que agem no sistema endócrino, presentes em esgotos brutos, tratados e águas superficiais (BERNARDELLI et al., 2015; BRANDT et al., 2013; FROEHNER et al., 2011; GHISELLI, 2006; MONTAGNER; JARDIM, 2011; MOREIRA , 2009; PESSOA et al., 2014; TERNES et al., 1999a). Entretanto ainda são raras as publicações locais de resultados sobre a ação biológica dos interferentes endócrinos em amostras ambientais. O reconhecimento dos efeitos biológicos causados pela mistura e interação de compostos químicos permite avaliar a exposição dos organismos aos riscos. 
Os resultados de análises químicas permitem avaliar individualmente os poluentes reconhecidamente mais frequentes em águas residuárias, porém muitos outros produtos estáveis, substâncias em concentrações traços e aqueles transformados após os tratamentos biológicos permanecem sem que sejam identificados, embora sejam biologicamente ativos (BERGMAN et al., 2013; ESCHER; LEUSCH, 2012; FUKUSHIMA et al., 2014). As análises químicas têm alcance limitado do número de compostos por análise. Todavia, mesmo que todos os compostos de uma mesma amostra fossem identificados e quantificados, os efeitos de suas combinações continuariam indeterminados por esse tipo de análise porque os compostos interagem entre si e modificam suas respostas biológicas individuais (ESCHER; LEUSCH 2012).

Nesse contexto, bioensaios que quantificam os potenciais efeitos estrogênicos em águas residuárias que atingem as águas superficiais e as reservas hídricas da região metropolitana de São Paulo permitem prever os riscos associados à biota e à saúde humana. Estimar a estrogenicidade de esgotos brutos e tratados das estações de tratamento de esgotos. Este fato contribui para retratar a situação atual, propor discussões de monitoramento e controle acerca dos critérios de lançamentos de esgotos em águas superficiais. 


\section{Revisão Bibliográfica}

\subsection{Interferentes endócrinos}

O termo interferentes endócrinos surgiu nas primeiras publicações de Soto et al. (1991), Colborn et al. (1993), à medida que se consolidaram as evidências de alterações morfológicas, no desenvolvimento de embriões, fetos e neonatais, causadas pelos compostos DDT, DDE, PCBs e dietilbestrol (COLBORN; VOM SAAL; SOTO, 1993; SOTO et al., 1991). Os interferentes endócrinos mimetizam as ações biológicas naturais, agindo no sistema endócrino e provocando mudanças crônicas que alteram o metabolismo e podem desencadear doenças neurológicas, oncológicas e no sistema imunológico (HAO et al., 2009).

Os interferentes endócrinos são compostos orgânicos e inorgânicos que ocorrem em baixas concentrações (microgramas a picogramas por litro) em águas superficiais, agindo continuamente em níveis moleculares e teciduais em organismos aquáticos afetando o sistema endócrino de maneira sistêmica (ESCHER; LEUSCH, 2012).

Em 2001, em articulação internacional protagonizada pela Organização Mundial da Saúde (OMS) e Programa das Nações Unidas para o Meio Ambiente (UNEP), os poluentes orgânicos persistentes (POPs) que tiveram suas toxicidades reconhecidas na Convenção de Estocolmo pela qual estabeleceu-se um acordo entre 150 países para eliminar ou restringir os POPs, que entra em vigor a partir de 2004 (THUNDIYIL; SOLOMON; MILLER, 2007). Ao longo dos anos, esses poluentes vêm sendo continuamente monitorados, bem como o reconhecimento de seus efeitos no sistema endócrino (FIELD et al., 2006).

O Brasil firmou sua participação na Convenção de Estocolmo e compromissos a partir da publicação decreto Executivo $n^{0} 5472$ de 20 de junho de 2005. A convenção determina ações preventivas e inovações tecnológicas nos processos produtivos, de comercialização, disposição e uso dos POPs (MMA, 2012).

Substâncias do grupo de poluentes orgânicos persistentes como as bifenilas policloradas (PCBs), apesar de terem sido banidas ou restringidas, os efeitos perduram e foram identificados em organismos presentes nas áreas contaminadas devido à exposição e capacidade de bioacumulas. Esses compostos se espalharam e permaneceram em várias extensões em escala global (SCHWARZENBACH et al., 2010) e segundo Lamb et al. (2014), é difícil estabelecer relações conclusivas de causa e efeito endócrino direto dos POPs devido ao longo tempo que estes permanecem nos organismos. Esses autores observaram a relação de 
PCBs e a ocorrência de hiperplasia adrenocortical em focas do mar báltico, porém, não foi conclusiva a relação entre o mecanismo de ação dos PCBs e o órgão afetado (LAMB et al., 2014).

Em 2012, a Organização Mundial da Saúde (OMS) atualizou a classificação de interferentes endócrinos feita em 2002 mantendo os POPs e incluindo novos compostos. Substâncias plastificantes, compostos aromáticos policíclicos, halogenados e não halogenados fenólicos são menos persistentes e bioacumulativos que os POPs e foram denominados falsos persistentes porque têm meia vida variável, porém são continuamente difundidos no meio ambiente por meio do uso produtos domésticos que contém aditivos que são interferentes endócrinos (higiene pessoal, cosméticos e detergentes), além de muitos outros compostos presentes na excreção natural humana (medicamentos, metabólitos e hormônios sintéticos) e animal, bem como por dejetos agrícolas, industriais e municipais (CAÑEDO; ÁLVAREZ; CISNEROS, 2013; SCHWARZENBACH et al., 2010).

A classificação de interferentes endócrinos da OMS de 2012 está apresentada no Quadro. Tal classificação organiza os compostos em categorias, inseridas em quatro grandes grupos: compostos halogenados persistentes e bioacumulativos; compostos pouco persistentes e bioacumulativos; pesticidas, farmacêuticos, ingredientes de produtos de higiene pessoal; e outros compostos. O grupo denominado "outros compostos" inclui metais e compostos organometálicos, hormônios naturais (17 $\beta$-estradiol, estrona, testosterona) e fitoestrógenos, entre outros (KIDD et al., 2013).

Os hormônios sintéticos, como o 17a-etinilestradiol (EE2), por exemplo, são produzidos para fins de terapia de reposição hormonal ou utilizados em anticoncepcionais (TERNES; JOSS, 2008). Na classificação da OMS, o EE2 pertence ao grupo dos produtos farmacêuticos ou medicamentos (KIDD, et al. 2013). Porém, há autores que o classificam como xenoestrógeno, por ser um representante dos compostos produzidos pelo homem e que se liga aos receptores de estrógenos (LINTELMANN et al., 2003).

A classificação da OMS (2013) não especifica os subprodutos ou metabólitos ativos transformados a partir de compostos estáveis com atividade endócrina (Quadro). 
Quadro - Classificação de interferentes endócrinos agrupados e exemplificados em categorias.

\begin{tabular}{|c|c|}
\hline Classificação & $\begin{array}{c}\text { Exemplos específicos de interferentes endócrinos } \\
\text { por categoria* }\end{array}$ \\
\hline \multicolumn{2}{|c|}{ Compostos halogenados persistentes e bioacumulativos } \\
\hline Dioxinas & $\begin{array}{l}\text { dibenzodioxinaspolicloradas (PCDDs) } \\
\text { hexaclorobenzeno (HCB) } \\
\text { ácido perfluorooctanossulfônico (PFOS) } \\
\text { éter difenilpolibromado (PBDEs) } \\
\text { bifenilapolibromadas (PBBs) } \\
\text { toxafeno } \\
\underline{\text { diclorodifeniltricloroetano }}(\mathrm{DDT}) \\
\underline{\text { diclorodiclorofenil etileno }}(\mathrm{DDE}) \\
\text { lindane, endosulfan } \\
\text { hexabromociclododecano (HBCDD) } \\
\text { parafinas cloradas de cadeia curta (SCCP), ácido } \\
\text { perfluorooctanóico (PFOA), octaclorostireno, } \\
\text { bifenilapolicloradametilsulfonas }\end{array}$ \\
\hline Furanos & dibenzofuranospoliclorados (PCDF) \\
\hline Bifenilas & bifenilapolicloradas (PCBs) \\
\hline \multicolumn{2}{|c|}{ Compostos pouco persistentes e bioacumulativos } \\
\hline Compostos aromáticos & $\begin{array}{l}\text { ésters ftalatos, n-butilbenzeno, triclocarban, } \\
\text { hidroxinisolabutilada }\end{array}$ \\
\hline Compostos aromáticos policíclicos & benzopireno, benzoantraceno, pireno, antraceno \\
\hline Compostos fenólicos halogenados & $\begin{array}{l}\text { 2,4 diclorofenol, pentaclorofenol, hidroxi-PCBs, } \\
\text { hidroxi-PBDEs, tetrabromobisfenol-A, 2,4,6- } \\
\text { tribromofenol, triclosan }\end{array}$ \\
\hline $\begin{array}{l}\text { Compostos fenólicos não } \\
\text { halogenados }\end{array}$ & $\begin{array}{l}\text { bisfenol A, bisfenol F, bisfenol S, nonilfenol, } \\
\text { octilfenol, resorcinol }\end{array}$ \\
\hline \multicolumn{2}{|c|}{ Compostos orgânicos falso persistentes } \\
\hline Pesticidas atuais & $\begin{array}{l}\text { 2-4D, atrazina, carbaril, malation, mancozeb, } \\
\text { vinclozolin, procloraz, procimidona, clorpirofos, } \\
\text { fenitrofion, linuron }\end{array}$ \\
\hline $\begin{array}{l}\text { Compostos farmacêuticos, } \\
\text { hormônios de crescimento e } \\
\text { ingredientes de produtos de higiene } \\
\text { pessoal }\end{array}$ & $\begin{array}{l}\text { dietilestilbestrol, etinilestradiol, tamoxifeno, } \\
\text { levonorgestrel, inibidores seletivos de serotonina, } \\
\text { flutamida, 4-metil benzilidenocânfora, 3-metil } \\
\text { benzilidenocânfora, octil-metoxicinamato, parabenos, } \\
\text { metil siloxanoscíclicos, galaxolida }\end{array}$ \\
\hline \multicolumn{2}{|l|}{ Outros compostos } \\
\hline $\begin{array}{l}\text { Metais e compostos } \\
\text { organometálicos }\end{array}$ & $\begin{array}{l}\text { arsênio, cádmio, chumbo, mercúrio, metilmercúrio, } \\
\text { tributiltina, trifeniltina }\end{array}$ \\
\hline Hormônios naturais & $\underline{17 \beta \text {-estradiol, estrona, testosterona }}$ \\
\hline Fitoestrógenos & $\begin{array}{l}\text { isoflavonas (genisteína, daidzeína), micotoxinas } \\
\text { (zearalenona), flavonoidesprenilados }\end{array}$ \\
\hline
\end{tabular}


Entre os hormônios naturais humanos ou endógenos, estão os estrógenos, responsáveis pela diferenciação sexual durante a fase de desenvolvimento, amadurecimento e ao longo dos ciclos ovarianos. São estrógenos naturais a estrona (E1), o 17ß-estradiol (E2) e o estriol (E3), que são derivados do colesterol (TERNES; JOSS, 2008), estes hormônios endógenos de importância ambiental. Na Figura 1, os dois primeiros, estrona e estradiol, têm estruturas e propriedades similares (SONG; WANG; LIAN, 2013).

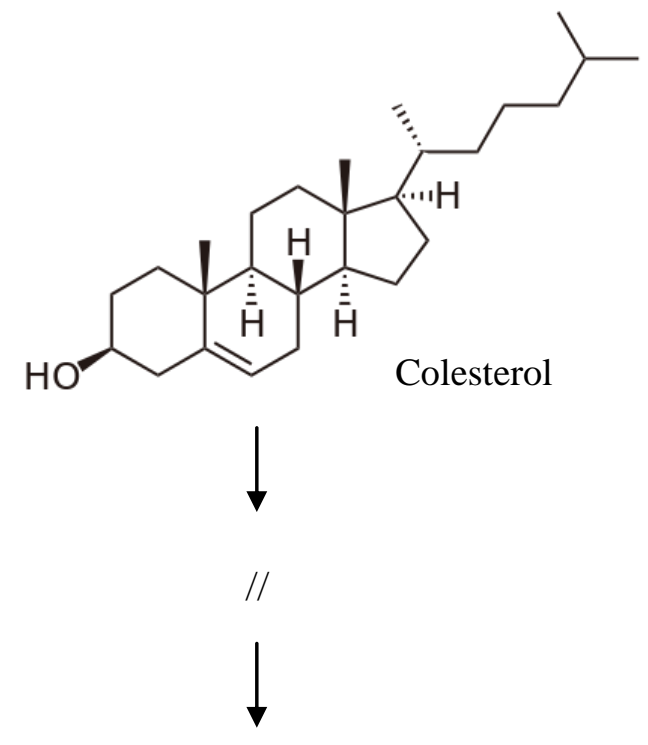

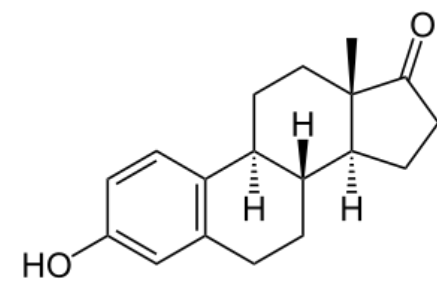

Estrona

(E1)

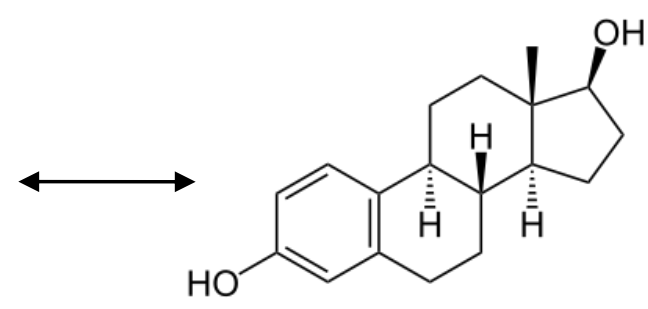

17ß-estradiol (E2)<smiles>CCC1CCc2cc(O)ccc2[C@@H]2C[C@H](O)[C@@H](O)[C@@]2(C)CC1</smiles>

Estriol

(E3)

Figura 1 - Esquemas representativos da estrutura química de hormônios.

Fonte: Ternes; Joss (2008). 
Na Figura 2 observa-se a estrutura química dos xenoestrógenos, dietilbestrol, bisfenolA e nonilfenol, em que é possível perceber diferenças estruturais significativas. Geralmente os compostos estrogênicos têm em comum o anel fenólico, assim como o estrógeno endógeno. No entanto, esta estrutura química não representa uma característica comum a todos os compostos estrogênicos porque muitos deles podem ser metabólitos de outros compostos e não apresentarem esta estrutura (KIDD et al., 2013).

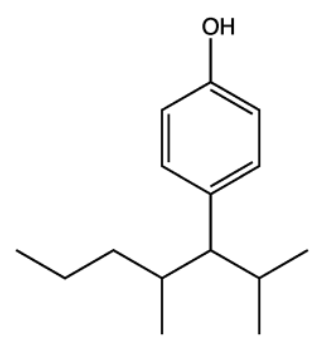

Nonilfenol

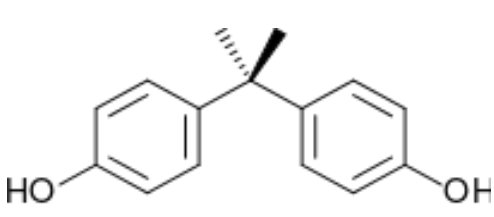

Bisfenol-A

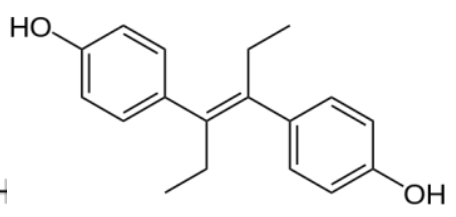

Dietilstilbestrol

Figura 2 - Representação de estruturas químicas variadas de interferentes endócrinos.

Os interferentes endócrinos podem ser androgênicos, estrogênicos, tireoideanos ou corticoides (DE COSTER; VAN LAREBEKE, 2012). As funções hormonais dos interferentes endócrinos são ativadas pelas suas ligações em seus respectivos receptores. Entretanto, os interferentes endócrinos apresentam múltiplos mecanismos de ação e podem agir como agonista, quando mimetiza um determinado hormônio estrogênico ou androgênico, ou como antagonista, quando bloqueia um hormônio, ligando-se ao seu receptor antiestrogênico ou antiandrogênico (COLBORN; VOM SAAL; SOTO, 1993). A ação biológica como agonista pode ser desencadeada por suas interações com receptores hormonais no genoma humano (há pelo menos 48 receptores hormonais conhecidos) (ESCHER; LEUSCH, 2012). Entretanto, há pelo menos dois principais receptores nucleares: ER $\alpha$ e ER $\beta$. Alguns órgãos, como útero e ovários, possuem células com ambos os receptores em diferentes quantidades e são regulados por ações dos hormônios (TERNES; JOSS, 2008). A ação biológica também pode ser direta em qualquer proteína que regule o hormônio para célula ou tecido alvo (BERGMAN et al., 2013). Há compostos, a exemplo das bifenilas hidroxiladas policloradas (PCBs-OH), que interferem na produção de hormônios inibindo a enzima sulfotransferase estrogênica e ocasionando elevações de seus níveis estradiol bioativos no sangue (FISHER, et al. 20014). 
Outros, como a atrazina, induzem a enzima aromatase à conversão de testosterona em estradiol (ESCHER; LEUSCH, 2012).

Os interferentes endócrinos são usualmente chamados de compostos estrogênicos quando desencadeiam a resposta biológica chamada estrogenicidade ou atividade estrogênica, via ativação dos receptores estrogênicos ou por outro mecanismo de ação. Alguns deles têm também outras ações biológicas além da estrogênica, sejam medicamentosas (fenobarbital) ou tóxicas como, fungicida (fenarimol), inseticida (fenitrotion) entre outras (SANSEVERINO et al., 2009).

Os interferentes endócrinos podem causar efeitos em qualquer fase do ciclo de vida. Entretanto, durante a gestação humana há maior susceptibilidade aos interferentes endócrinos porque os mesmos podem atravessar a barreira placentária e interferir no desenvolvimento embrionário, fetal e neonatal, desenvolvendo alterações metabólicas na infância ou alterações na capacidade reprodutiva dos organismos porém, algumas vezes podem ser somente percebidas na fase adulta, (KIDD et al., 2013) e em outras, há indivíduos que não atingem a maturidade (COLBORN; VOM SAAL; SOTO, 1993). O aumento na incidência de casos de endometriose e de puberdade precoce, além da crescente incidência de câncer nos testículos e próstata, estiveram relacionados às regiões geográficas de maiores concentrações ambientais de interferentes endócrinos (MARTIN et al., 2007).

Estabelecer as relações diretas de causa e efeito dos compostos nas populações afetadas são desafios a serem melhor compreendidos. Há o agravante do modo diverso como os interferentes endócrinos podem interagir com os receptores e gerar respostas que nem sempre seguem os padrões toxicológicos tradicionais de dose-resposta. Normalmente, a cinética de dose-resposta na toxicologia tradicional corresponde a concentrações menores ou doses baixas que não causam efeitos, sendo que as doses progressivas é que sensibilizam e determinam a resposta biológica ou efeito tóxico. Mas, para alguns interferentes endócrinos como o p-nonilfenol, atrazina, bisfenol, triclosan, entre outros, a dose-resposta contraria os modelos convencionais porque não segue os padrões reconhecidos na toxicologia clássica, que corresponde a tradicional curva monotônica de dose-resposta (FAGIN, 2012). Conforme observado na Figura 3 de curva monotônica, o aumento de dose de genisteína apresentou correspondência com o aumento do efeito de ganho de peso uterino em ratas (OHTA et al., 2012). 


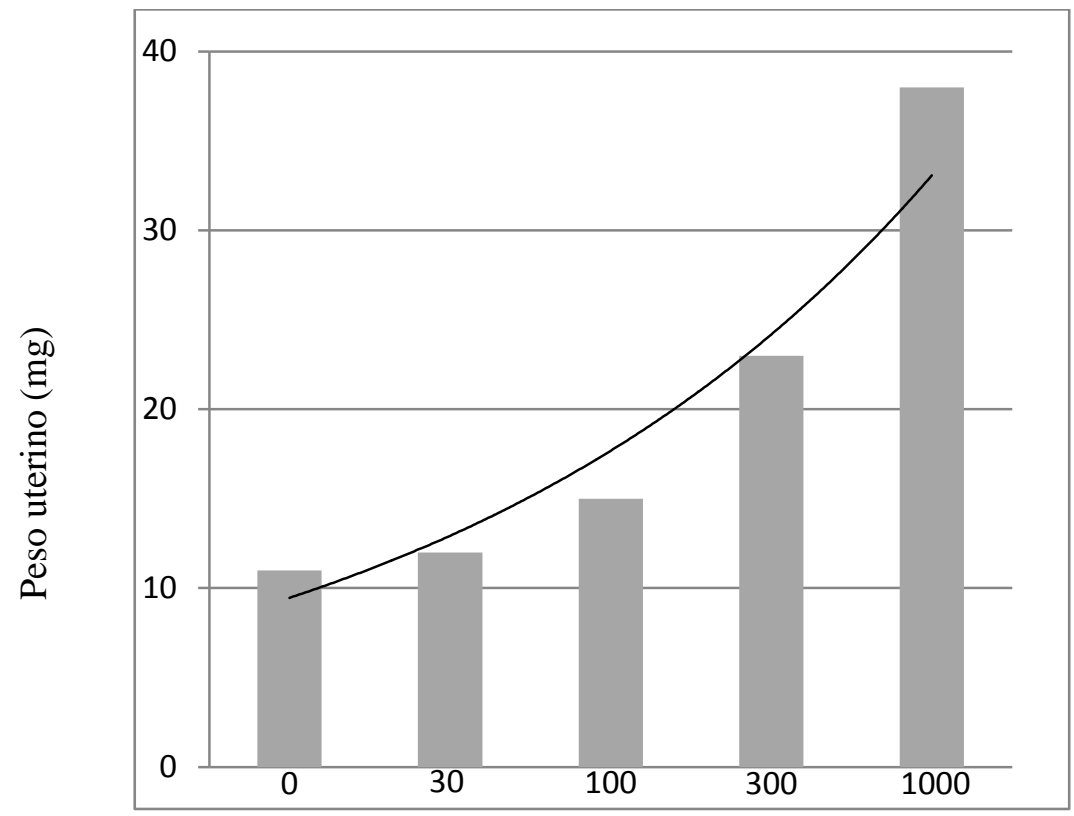

Doses de genisteína $(\mathrm{mg} / \mathrm{kg})$

Figura 3 - Curva monotônica do efeito da genisteína no aumento de peso uterino em roedoras fêmeas.

Fonte: Adaptado de Ohta et al. (2012).

Todavia, os resultados encontrados por Vandenberg et al. (2012) e Vom Saal e Bronson (1978) apresentaram efeitos que são atípicos porque os aumentos de doses dos compostos não apresentaram correspondência com aumento de efeitos; desse modo, o efeito pode ser identificado numa concentração mais baixa e numa concentração mais elevada não produzir efeito algum. Neste ponto, há o reconhecimento dos riscos por parte dos órgãos regulatórios como o norte-americano, National Institute of Environmental Health Sciences (NIEHS), porém há a dificuldade em estabelecer concentrações individuais dos compostos e a recomendação deste órgão é de cautela para a determinação de doses aceitáveis de compostos. O fato decorre da ausência de resultados conclusivos sobre o assunto para embasar os limites máximos ambientais aceitáveis, pois dependem da permanência dos compostos no meio ambiente e do tempo de exposição que os organismos estejam expostos, entre outros fatores (FAGIN, 2012; VOM SAAL; BRONSON, 1978; VANDENBERG et al., 2012).

A Comunidade Europeia selecionou 33 compostos ou grupos de compostos considerados prioritários e que são controlados pelas diretivas 2000/60/CE e 2008/105/CE do parlamento europeu e do conselho ambiental responsável por monitorar substâncias 
prioritárias no domínio da política da água. Em 2012, a Comissão Europeia ambiental propôs que as atuais diretivas acima citadas fossem revisadas, de modo a incluir novos compostos, totalizando 44 substâncias. A proposta é que as diretivas vigentes sejam revisadas pelo menos a cada quatro anos. Os novos compostos sugeridos são considerados conforme as características de persistência, bioacumulação e efeitos tóxicos, e entre eles estão incluídos dois potentes estrógenos: 17 $\alpha$-etinilestradiol e 17ß-estradiol. As concentrações máximas inclusão nas diretivas em relação aos dois estrógenos estão indicadas na Tabela 1 (Comissão Europeia, 2012).

Tabela 1 - Compostos estrogênicos e concentrações máximas admissíveis em águas de superfícies interiores. A Comissão Europeia ambiental propôs para inclusão na lista de compostos prioritários para regulamentação.

\begin{tabular}{ll}
\hline Composto & $\begin{array}{l}\text { NQA/ MA } \\
\text { águas de superfícies interiores } \\
(\mathbf{n g} / \mathrm{L})\end{array}$ \\
\hline $\begin{array}{l}17 \alpha \text {-etinilestradiol } \\
17 \beta \text {-estradiol }\end{array}$ & 0,035 \\
& 0,40
\end{tabular}

Fonte: Comissão Europeia (2012).

${ }^{1}$ Este parâmetro constitui a norma de qualidade ambiental expressa em valor médio anual (NQA-MA).

${ }^{2}$ As águas de superfície interiores compreendem os rios, lagos e todas as represas artificiais ou áreas modificadas afins.

Certamente, as concentrações sugeridas na Tabela 1 são bastante baixas, como no caso de 0,035 ng/L de 17 $\alpha$-etinilestradiol, o que requer equipamentos de análises químicas sensíveis à estes níveis de quantificação e requer capacitação tecnológica comum entre os países, porque geralmente ensaios sensíveis atingem o limite de 0,15 ng (METCALFE et al., 2013) . Na última atualização de novembro de 2015, a revisão destes valores ainda não foi aprovada pela comissão europeia e estão sendo avaliados os efeitos estrogênicos da mistura de compostos contidos nas águas por meio de bioensaios deverão ser padronizados para determinar valores de estrogenicidade. Assim, as avaliações de interferentes endócrinos são realizadas em grandes centros de estudos de diversos países, que tem como meta integrar vários bioensaios para detectar quais efeitos biológicos são predominantes e quais os grupos de compostos associados aos efeitos determinados. A partir da mistura de efeitos biológicos dos diversos bioensaios, busca-se identificar quais os principais compostos que contribuem nas respostas biológicas (ALTENBURGER et al., 2015). 
A agência europeia (REACH) é a estrutura responsável por integrar as políticas sobre compostos químicos, atua principalmente no controle de interferentes endócrinos nos processos produtivos em que estes compostos são utilizados como insumos de produtos. Deste modo, há proibição do uso de polibromobifenil (PBB) em artigos têxteis que tenham contato com a pele; em outros casos a restrição é de que compostos como o cádmio, não ultrapassem a concentração de $0,01 \%$ do peso do material plástico produzido e a produção sobretaxada. Quanto aos nonilfenóis, estes apenas podem ser utilizados para fins de limpeza industriais e os resíduos gerados devem ser incinerados ou tratados conforme a regulamentação de 2006, proposta por esta agência. Estas medidas visam restringir o uso destes produtos e suas substituições em processos produtivos, com a tendência de redução de suas concentrações nas águas (ECHA, 2015).

\subsection{Ocorrência de interferentes endócrinos}

A ocorrência de interferentes endócrinos em águas superficiais pode ter como origem fontes pontuais e difusas. São exemplos das primeiras, indústrias produtoras ou que utilizam em seus processos produtivos compostos que são interferentes endócrinos. Estes estão contidos em produtos de consumo gerados pelas indústrias de alimentos, embalagens, higiene pessoal, medicamentos, produtos veterinários, produtos agrícolas, limpeza e retardantes de chamas entre outros (GAVRILESCU et al., 2014). Esses produtos acumulam-se nas águas residuárias e nos efluentes industriais que chegam às estações de tratamento de esgotos ou atingem diretamente as águas superficiais.

O consumo e descarte inapropriado desses produtos levam ao acúmulo de interferentes endócrinos em esgotos brutos, lodos de estações de tratamento de esgotos e solos (CAÑEDO; ÁLVAREZ; CISNEROS, 2013; LUST et al., 2015; RUAN et al., 2015). Os sistemas convencionais de tratamento de esgoto não removem completamente esses compostos porque não foram desenvolvidos para essa finalidade e necessitariam, portanto, ter suas condições de tratamentos modificadas para isso. Desse modo, os interferentes endócrinos permanecem nos esgotos após o tratamento e são detectados frequentemente em águas superficiais, sedimentos e até mesmo em águas de abastecimento (SOLANO et al., 2015; ESTEBAN et al., 2014; JIANG; ZHOU; SHARMA, 2013).

Em áreas rurais há fontes como os resíduos da agropecuária que somam-se às descargas de poluentes nas águas superficiais. Entre eles, estão os hormônios eliminados por 
meio das excretas de animais e atingem às águas como fonte difusa em proporções variáveis que não estão bem estabelecidas (LAURENSON et al., 2014).

Os compostos atmosféricos gerados pela combustão nos grandes centros urbanos também são fontes difusas que contribuem para a contaminação das águas por meio de chuvas e posterior escoamento das águas (CAMPBELL et al., 2006; JAROŠOVÁ et al., 2014; JOHNSON; SUMPTER, 2001; SCHWARZENBACH et al., 2010). Conforme a Figura 4, são indicadas algumas fontes de contaminação e os modos a permanência dos compostos nos corpos hídricos. Conforme Campbell et al. (2006), dois fatores contribuem na dispersão dos compostos estrogênicos no meio aquático, primeiro quando se associam aos coloides ou segundo quando tornam-se mais solúveis conforme elevações de $\mathrm{pH}$. Portanto, tanto a permanência quanto a dispersão expõe os organismos aquáticos aos riscos e estratégias devem consideradas para minimizar o lançamento de compostos estrogênicos.

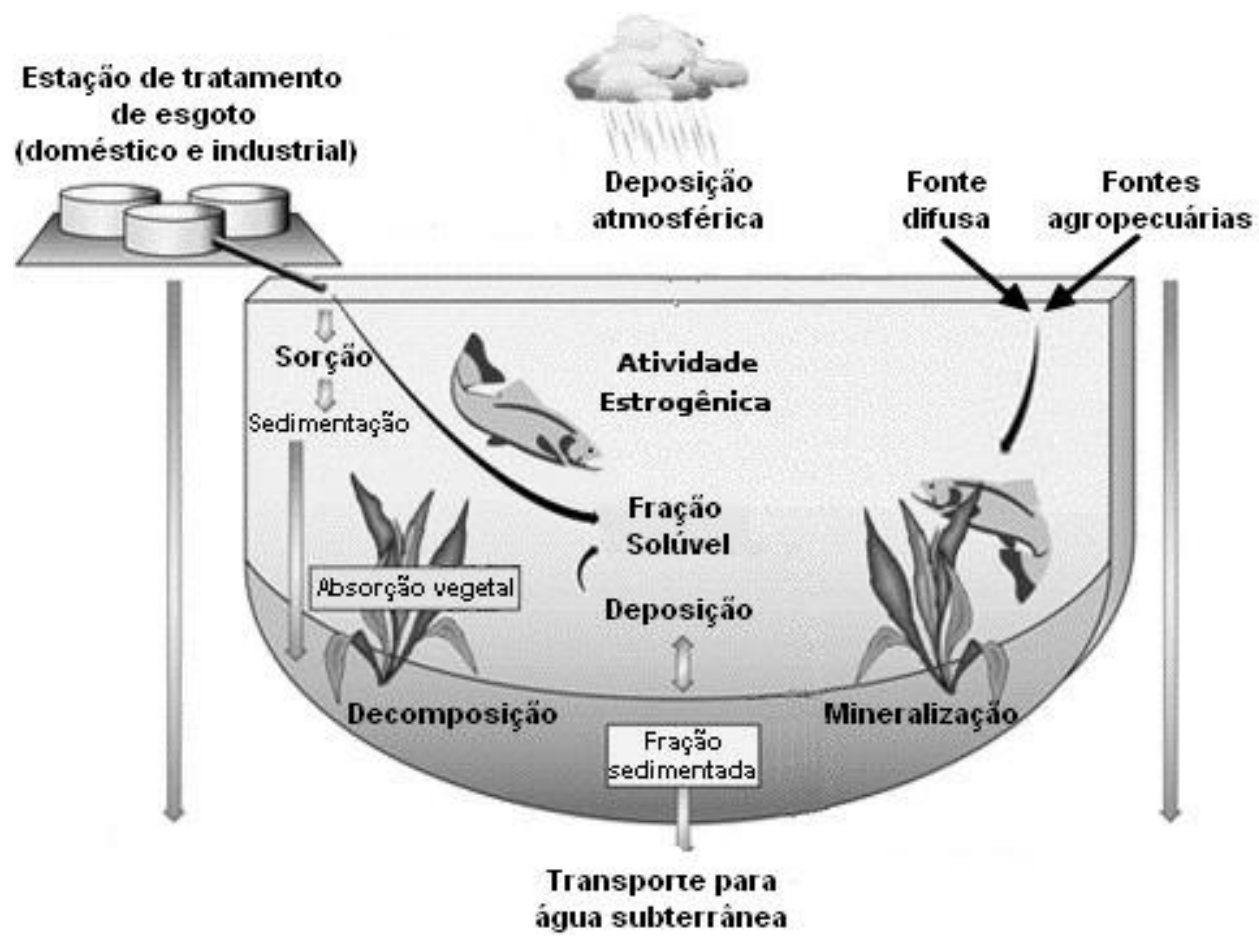

Figura 4 - Representação esquemática de fontes pontuais e difusas de interferentes endócrinos, processos físicos e biológicos em meio aquático.

Fonte: Adaptado de Campbell et al. (2006).

A presença e permanência desses contaminantes em águas superficiais dependem de propriedades físico-químicas dos compostos, condições ambientais e de saneamento e são influenciadas por hábitos de consumo, diferenças socioculturais, entre outros fatores (GAVRILESCU et al., 2014 ; LUO et al., 2014). 
Entre os diversos interferentes endócrinos frequentemente presentes e ativos nas águas, podemos destacar os hormônios estrogênicos esteroides, como o estriol, 17 $\beta$-estradiol, $17 \alpha$-etinilestradiol e a estrona. Entre os hormônios estrogênicos, há os sintéticos, como o contraceptivo hormonal levonorgestrol, que têm seus metabólitos excretados pelo sistema urinário feminino. Durante o processo biológico em estações de tratamento de esgotos, esses metabólitos se convertem novamente em forma ativa. Há exemplos de interferentes endócrinos de difícil degradação durante os processos de tratamentos de esgoto, que como triclosan (antimicrobiano), pode ser convertido a metiltriclosan ainda mais persistente no meio ambiente e pode ser biacumulado nos organismos (KIDD et al., 2013). Os metabólitos ativos desses e de outros interferentes endócrinos são capazes de se combinar com outros compostos, originando misturas complexas de efeitos sinérgicos, ou seja, combinação de efeitos de compostos que potencializam efeitos de outros compostos, ou efeito aditivo que são os efeitos que se somam uns aos outros (ALDA; BARCELÓ, 2001; LAURENSON et al., 2014).

A composição dos esgotos brutos e dos esgotos tratados é bastante variável, no entanto alguns autores apontam que os hormônios naturais e sintéticos contribuem com $80 \%$ da estrogenicidade dessas matrizes (GAVRILESCU et al., 2014; GORGA et al., 2014; SALSTE et al., 2007; SUI et al., 2011).

Alguns estudos nacionais de quantificação de interferentes endócrinos foram apresentados na revisão de Aquino et al. (2013) e foram atualizados na Tabela 2, apontando a ocorrência dos principais compostos estudados no Brasil (AQUINO; BRANDT; CHERNICHARO, 2013). 
Tabela 2 - Estudos nacionais de ocorrência de hormônios naturais e sintéticos em diferentes matrizes ambientais

\begin{tabular}{|c|c|c|c|c|c|}
\hline \multirow{2}{*}{ Classe } & \multirow{2}{*}{ Composto } & \multicolumn{3}{|c|}{ Ocorrência $(n g / L)$} & \multirow{2}{*}{ Referência } \\
\hline & & $\begin{array}{l}\text { Esgoto } \\
\text { bruto }\end{array}$ & $\begin{array}{l}\text { Esgoto } \\
\text { tratado }\end{array}$ & $\begin{array}{l}\text { Água } \\
\text { superficial }\end{array}$ & \\
\hline \multirow{13}{*}{$\begin{array}{l}\text { Hormônios } \\
\text { Naturais }\end{array}$} & \multirow{5}{*}{ estrona } & 40 & - & - & Ternes et al.,1999 ${ }^{\mathrm{a}}$ \\
\hline & & 4830 & 4130 & $3500-5000$ & Ghiselli, 2006 \\
\hline & & $870-1380$ & $<\mathrm{LD}$ & - & Froehner et al., 2011 \\
\hline & & - & - & $<16$ & Montagner e Jardim, 2011 \\
\hline & & $<40-4350$ & $<40-430$ & - & Souza, 2011 \\
\hline & \multirow{8}{*}{$\begin{array}{l}17 \beta- \\
\text { etinilestradiol }\end{array}$} & 21 & - & - & Ternes et al.,1999 ${ }^{\mathrm{a}}$ \\
\hline & & 6690 & 5560 & $1900-6000$ & Ghiselli, 2006 \\
\hline & & $1330-2270$ & $490-760$ & - & Froehner et al., 2011 \\
\hline & & - & - & $<45-6806$ & Montagner e Jardim, 2011 \\
\hline & & $<40-7400$ & $<40-4000$ & - & Souza, 2011 \\
\hline & & - & - & $106-6800$ & Montagner, 2007 \\
\hline & & - & - & $<1-37$ & Moreira et al., 2009 \\
\hline & & $<9,3-31$ & $<9,3$ & - & Queiroz et al., 2012 \\
\hline \multirow{6}{*}{$\begin{array}{l}\text { Hormônio } \\
\text { Sintético }\end{array}$} & \multirow{6}{*}{$\begin{array}{l}17 \alpha- \\
\text { etinilestradiol }\end{array}$} & 5810 & 5040 & $1200-3500$ & Ghiselli, 2006 \\
\hline & & $600-1260$ & $<\mathrm{LD}-470$ & - & Froehner et al., 2011 \\
\hline & & - & - & $<17-4390$ & Montagner e Jardim, 2011 \\
\hline & & $<20-5230$ & $<20-1200$ & - & Souza, 2011 \\
\hline & & - & - & $<1-54$ & Moreira et al., 2009 \\
\hline & & $<12,4<41,3$ & $<12,4$ & - & Queiroz et al., 2012 \\
\hline
\end{tabular}

Fonte: Adaptado de Aquino; Brandt; Chernicharo (2013).

De fato, estudos realizados no estado de São Paulo detectaram a presença de interferentes endócrinos em pontos críticos, inclusive em mananciais que servem de abastecimento de água para consumo humano. Na bacia do rio Atibaia, as amostras confirmaram a presença de 17ß-estradiol, bisfenol-A, colesterol, entre outros (JARDIM et al., 2012; GHISELLI, 2006; MONTAGNER, 2007; SODRÉ et al., 2007). Resultados similares foram encontrados em outros mananciais, como a bacia do rio Mogi-Guaçu (LOPES et al., 2010), rio Sorocaba e rio Cotia (JARDIM et al., 2012).

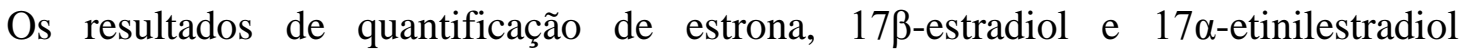
apresentados na Tabela 2 variaram muito em concentração para o mesmo composto entre os estudos. Os resultados encontrados por Souza (2011) mostram que a estrona, o $17 \alpha$ - 
etinilestradiol e o $17 \beta$-estradiol tiveram ordens de grandeza distintas entre valores mínimos e máximos nos esgotos brutos. Esses resultados indicam que as Estações de Tratamento de Esgotos (ETEs) estão susceptíveis às altas oscilações nas concentrações de compostos que chegam até elas.

Conforme Ghiselli (2006), os estrógenos foram pouco removidos das estações de tratamento de esgoto pelo sistema de lodos ativados, como pode ser observado no caso de $17 \beta$-estradiol quantificado em $6690 \mathrm{ng} / \mathrm{L}$ em esgotos brutos e $5560 \mathrm{ng} / \mathrm{L}$ em esgoto tratado, demonstrando baixa remoção do composto. Neste mesmo estudo, outro agravante foi a detecção de valores elevados (até 6000 ng/L) em águas superficiais para o mesmo composto, mostrando o riscos estrogênicos destas águas de valores comparáveis aos esgotos brutos. Os resultados de Ghiselli (2006) indicam que as águas superficiais podem ter atividade estrogênica originada diretamente por esgotos brutos, bem como por esgotos com tratamentos de remoção incompleta de interferentes endócrinos. Do mesmo modo, Montagner e Jardim (2011) evidenciaram concentrações muito elevadas de $17 \alpha$-estradiol (<4390ng/L) e $17 \beta$ estradiol $(<6800 \mathrm{ng} / \mathrm{L})$ em águas superficiais, mostrando a necessidade da melhoria de condições de tratamento destes esgotos e seus lançamentos nos corpos hídricos. 


\subsection{Fatores associados à remoção de interferentes endócrinos em estações de tratamento de esgotos}

O sistema de tratamento por lodos ativados é mais amplamente empregado no tratamento de esgotos de cidades industriais no Brasil e no exterior. Seu o objetivo primordial é a remoção de matéria orgânica carbonácea biodegradável por meio de oxidação biológica. Neste sistema a condição de TDH (tempo de detenção hidráulica) afeta sensivelmente as taxas de remoção de matéria orgânica (SPERLING, 2007).

A remoção de interferentes endócrinos dos esgotos brutos nas estações de tratamento de esgotos depende tanto das propriedades dos compostos quanto das condições operacionais das etapas dos processos de tratamento, em especial o TDH e a idade do lodo (OGUNLAJA; PARKER, 2015; PETRIE et al., 2014). Os dois mecanismos predominantes nas condições de remoção de compostos estrogênicos no sistema de lodos ativados são sorção e biodegradação (PESSOA et al., 2014).

Decerto, a sorção é uma propriedade físico-químico determinante para a remoção de interferentes endócrinos durante o processo de tratamento de esgotos e para a permanência em ambiente natural. A sorção é estimada pelo coeficiente de partição sólido-líquido $\left(\mathrm{K}_{\mathrm{d}}\right)$. O $\mathrm{K}_{\mathrm{d}}$ associa-se aos mecanismos de adsorção e absorção (AQUINO; BRANDT; CHERNICHARO, 2013). A adsorção é a capacidade de certos compostos serem atraídos e aderidos à superfície de contato de materiais sólidos ou lodo, provocada por um excesso de energia livre (ANDERSEN et al., 2003; PETRIE et al., 2014).

A adsorção de hormônios estrogênicos em sedimentos foi observada em ambientes naturais, por meio da detecção de estrona e $17 \beta$-estradiol em sedimentos na baía da Jamaica. Estes compostos mantiveram-se adsorvidos aos sedimentos e com atividade estrogênica; houve correlação entre as proporções dos compostos encontradas no ambiente natural e lançamento de esgotos tratados de seis ETEs na baía. Os autores concluíram que os compostos estrona e $17 \beta$-estradiol têm afinidade moderada (1,71 e 1,56 $\mathrm{K}_{\mathrm{d}}$ respectivamente) aos sedimentos e podem permanecer estáveis quando depositados aos sedimentos de ambiente natural (REDDY; BROWNAWELL, 2005). Entretanto, a sorção em ambiente natural não é linear variando de 0,57 a 0,83 de $\mathrm{K}_{\mathrm{d}}$ de modo que podem ser transportados para as águas superficiais ou subterrâneas (YIN; KOOKANA; RU, 2002).

Nas estações de tratamento de esgotos a remoção dos poluentes por sorção nos sólidos suspensos é significativa no lodo primário e secundário. A remoção ocorre por dois 
mecanismos: pela absorção na fração lipídica do lodo na sedimentação primária; e adsorção no lodo, que é dependente da força de interações eletrostáticas dos compostos carregados positivamente com a superfície negativa dos microrganismos do lodo (GRASSI; RIZZO; FARINA, 2013).

A propriedade lipofílica dos interferentes endócrinos determina sua capacidade de interação com o lodo. Esta propriedade é medida pelo coeficiente de partição octanol-água $\left(\mathrm{K}_{\mathrm{ow}}\right)$. Uma regra básica aplicada entre a relação de sorção e $\log \mathrm{K}_{\mathrm{ow}}$ associa que compostos com $\log \mathrm{K}_{\mathrm{ow}}<2,5$ têm baixo potencial de sorção; entre 2,5 $<\log \mathrm{K}_{\mathrm{ow}}<4,0$ indica potencial moderado; e $\log \mathrm{K}_{\mathrm{ow}}>$ 4,0 alto potencial de sorção (AQUINO; BRANDT; CHERNICHARO, 2013). Como exemplos de hidrofóbicos moderados estão os estrógenos $17 \beta$-estradiol e o17 $\alpha$ etinilestradiol (BRANDT et al., 2013; LUO et al., 2014).

A adsorção dos compostos à superfície de matéria orgânica varia conforme a polaridade destes materiais em suspensão e conteúdo de carbono orgânico. Este mecanismo é medido pelo coeficiente $\left(\mathrm{K}_{\mathrm{oc}}\right)$ que é a medida da tendência das substâncias orgânicas serem absorvidas por materiais sólidos e sua concentração em equilíbrio na água. Compostos com $\log$ de $\mathrm{K}_{\mathrm{oc}}$ elevado possui maior sorção lodo (BIRKETT; LESTER, 2003).

Os compostos absorvidos no lodo são biodegradados conforme a biodisponibilidade $\mathrm{e}$ as concentrações de compostos, além da biomassa suficiente para transformá-los. A biodisponibilidade dos compostos por sua vez depende da solubilidade (AQUINO; BRANDT; CHERNICHARO, 2013). A solubilidade é influenciada por diversos fatores tais como temperatura, luminosidade, potencial redox, o $\mathrm{K}_{\mathrm{ow}}$ entre outras (GHISELLI; JARDIM, 2007). A solubilidade dos estrógenos diverge entre si, a exemplo dos naturais (13 mg/L) em ambientes aquáticos e com maior solubilidade que os hormônios sintéticos $(4,8 \mathrm{mg} / \mathrm{L})$ (CAMPBEL et al., 2006; YIN; KOOKANA; RU, 2002; MONTAGNER, 2007).

A atividade microbiana é mais eficiente na degradação de compostos mais simples, enquanto as estruturas químicas mais complexas, de cadeias longas e ramificadas, são mais recalcitrantes, como os compostos saturados e aromáticos, que são menos biodegradáveis (BIRKETT; LESTER, 2003).

Os sistemas convencionais de tratamentos biológicos têm microrganismos melhor adaptados à degradação de compostos mais comuns e mais simples, e a eficiência de remoção dos tratamentos biológicos de poluentes emergentes pode eventualmente ser aprimorada por adaptações, como otimização das condições operacionais que favoreçam diversificação da biota ou recorrer a estratégias que combinem sistemas mais avançados (GRASSI; RIZZO; FARINA, 2013). 
A eficiência de remoção de compostos estrogênicos por sistema de lodos ativados diverge entre os autores entre 60\% e 80\% (BARONTI et al., 2000; ESPERANZA et al., 2004; JIANG; ZHOU; SHARMA, 2013; JOHNSON; SUMPTER, 2001; MICHAEL et al., 2015; TERNES et al., 1999a). Em uma revisão de estudos de 2009 a 2011, Luo et al. (2014) detectaram taxas de remoção de estrógenos acima de $70 \%$ em processo de tratamento convencional por lodos ativados. Os autores observaram uma variada eficiência de remoção conforme o composto estrogênico: 17 $\beta$-estradiol (98\%), estriol (100\%), estrona (82\%) e 17 $\alpha$ etinilestradiol (71\%) (LUO et al., 2014).

O bioensaio YES foi utilizado para quantificar atividade estrogênica em ETEs e os resultados demonstram eficiência acima de $90 \%$ em sistemas de lodos ativados porém, foi quantificado o efeito da mistura de compostos, sem que fossem identificados quais os compostos removidos (BRAGA et al., 2005; COLEMAN et al., 2008; LEUSCH et al., 2006).

Geralmente, nas ETEs convencionais os TDHs variam de 6 a 8 horas e a idade do lodo de 4 a 10 dias (SPERLING, 2007). As modificações entre estas variáveis e a melhoria de eficiência de remoção de estrógenos foram observadas nos estudos de BERNARDELLI (2014), IFELEBUEGU (2011), LUO et al.(2014) e PETRIE et al. (2014).

Petrie et al. (2014) apontam na Figura 5, que a idade do lodo elevada, durante o tratamento aeróbico, aumenta o mecanismo de interação dos compostos com as partículas sedimentáveis e ao lodo, que é determinante para elevar as taxas de adsorção e biodegradação respectivamente (PETRIE et al., 2014). Segundo esses autores, o aumento da idade do lodo de 3 para 10 dias aumentou a biodegradação de estrona (E1), estriol (E3) e 17 -estradiol (E2) e foi associada à elevação da contagem de bacteriana com crescimento de bactérias capazes de degradar estrógenos. Entretanto, idades do lodo superiores a 10 dias não aprimoram a biodegradação, porém para o composto sintético $17 \alpha$-etinilestradiol que é mais persistente após os tratamentos convencionais a idade do lodo de 27 dias aprimorou sua remoção por sorção durante o tratamento aeróbico (PETRIE et al., 2014). 


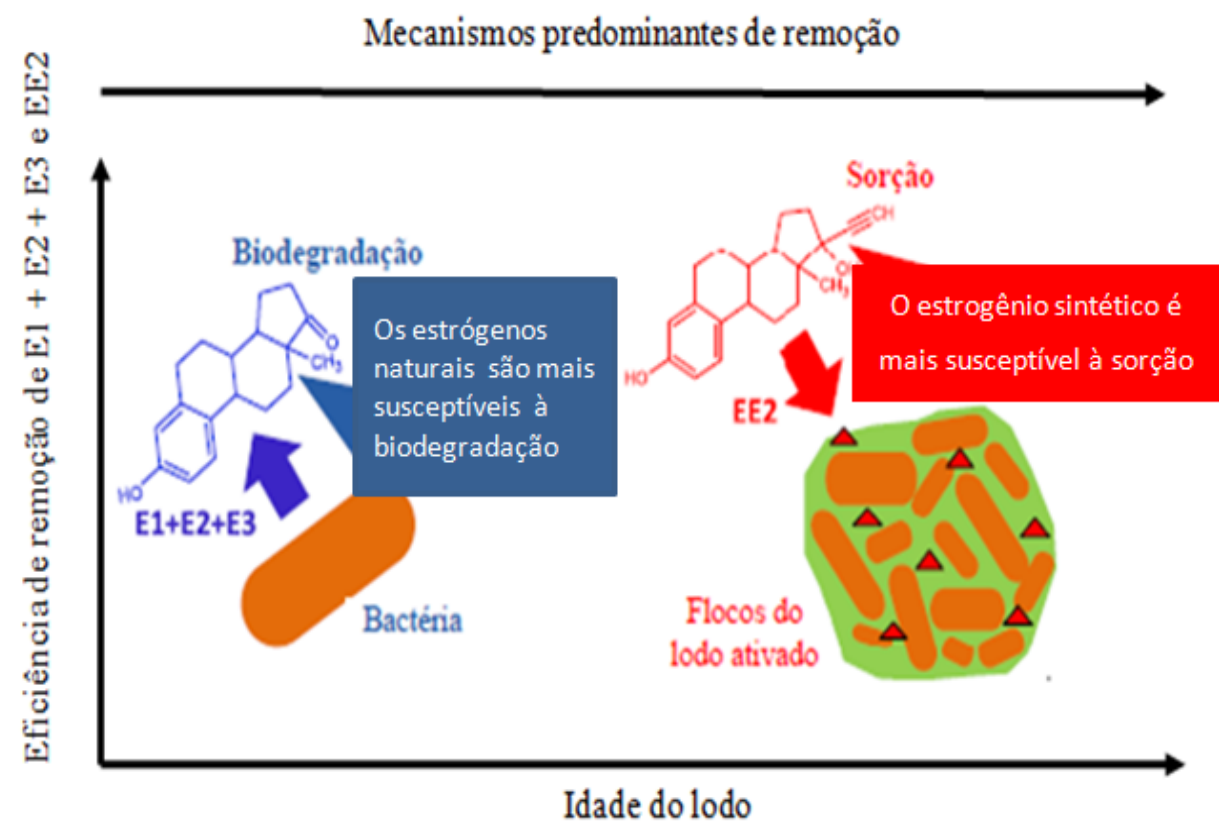

Figura 5 - Relação entre os mecanismos de sorção e biodegradação na remoção de estrógenos.

Fonte: Petri et al., (2014).

Os TDHs altos são importantes na remoção de compostos hidrofóbicos como os hormônios (VERMEIRSSEN; SUTER; BURKHARDT-HOLM, 2006) e estão associados a capacidade ampliada de adsorção no lodo devido ao maior tempo para que este mecanismo ocorra (TERNES et al.,1999a); a degradação biológica, pode favorecer a biodegradabilidade de compostos de maior recalcitrância e clivagem dos anéis fenólicos, já que que estes compostos podem servir como fontes de carbono para as bactérias heterotróficas (JOHNSON et al., 2005; MARGOT et al., 2013; TERNES, KRECKEL; MUELLER,1999b).

Arriaga et al. (2011) observaram remoção de 98\% dos estrógenos com TDH de 12 horas e idade do lodo de 60 dias em tratamento por biorreator em escala de bancada. A melhoria da eficiência foi atribuída pela maior adsorção à biomassa e ao aumento de condições de estresse bacteriano que induziu a metabolização de estrógenos por microrganismos nitrificantes na ausência de macronutrientes (ESTRADA-ARRIAGA; MIJAYLOVA, 2011).

Outros autores avaliaram a eficiência de remoção em idade do lodo de 30 dias (PESSOA et al., 2014). Os resultados variaram entre os compostos com eficiência de $84 \%$

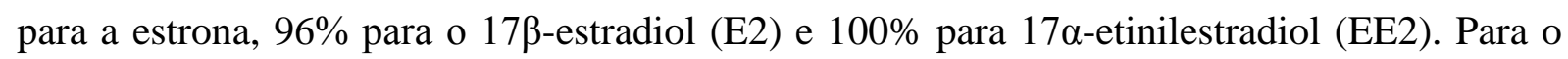
EE2 a remoção ocorre por degradação envolvendo a ação da enzima-chave (amônia 
monoxigenase) que catalisa a nitrificação (PESSOA et al., 2014). Outros autores observaram remoção de estrona até o limite de detecção da metodologia e instrumentação utilizada, remoção de $44 \%$ para EE2 e 63\% para E2 (FROEHNER et al., 2011); a remoção foi favorecida pelo tempo de detenção hidráulica (TDH) principalmente para os compostos hidrofóbicos.

A idade do lodo no processo de lodos ativados avaliado pelos autores foi de 30 dias, o que pareceu bastante superior aos valores convencionais podendo ser este uma das possíveis justificativas da alta eficiência apresentada no estudo. Pode-se esperar que a maior idade do lodo torne a concentração da biomassa mais intensa no tanque de aeração e associado a um maior período de contato com os interferentes endócrinos (JOHNSON, et al., 2005).

\subsection{Riscos ecológicos associados aos interferentes endócrinos e bioensaios para análise de atividade estrogênica}

O interesse ambiental e científico de identificar e quantificar interferentes endócrinos decorre de sua crescente presença em águas superficiais e aos impactos ecológicos por eles ocasionados. Desse modo, agências ambientais norte-americana e europeia vêm aprimorando as estratégias de análise dos riscos ambientais, para controle da frequência e das concentrações de interferentes endócrinos em ambientes aquáticos e proteção da saúde humana (ESCHER; LEUSCH; 2012; SANSEVERINO et al., 2009).

Por consequência, a avaliação de efeitos biológicos é separada em duas faixas denominadas pelo acrônimo do inglês "TIER" (Toxicity Identification Evaluation Response), uma sequência de procedimentos que empregam bioensaios para identificar ou isolar os compostos responsáveis por toxicidades. $\mathrm{Na}$ avaliação de toxicidade a atividade estrogênica está incluída na estratégia como efeito específico, entre outros efeitos que possam ser avaliados conjuntamente.

Inicialmente, a primeira faixa (Tier 1) utiliza ensaios in vitro e a razão dessa escolha deve-se à capacidade de esses bioensaios atender a necessidade de rapidez de resposta e de identificar e quantificar os efeitos em misturas de compostos nas amostras. Caso a primeira avaliação aponte toxicidade, há o seguimento para uma segunda faixa (Tier 2) que avalia, in vivo, como os compostos interagem em células-alvos desses ensaios e quais as respostas que causam nos sistemas reprodutivos ou nas fases de desenvolvimento dos organismos (SANSEVERINO et al., 2009). 
Os bioensaios in vitro em associação com as análises químicas auxiliam na identificação da ação de compostos presentes nas águas. Na junção dessas duas ferramentas de análise, são utilizados padrões sintéticos de composto como o 17ß-estradiol em concentrações conhecidas e compara-se com suas respostas estrogênicas quantificadas pelos bioensaios em amostras ambientais. Uma vez quantificado o efeito específico de estrogenicidade pode-se investigar quais os principais compostos estrogênicos que contribuíram para o efeito observado.

As respostas de atividades estrogênicas podem variar conforme a sensibilidade dos bioensaios, os organismos utilizados e os mecanismos de ação dos compostos que os bioensaios são capazes de quantificar. Ainda assim, é possível estabelecer a relação entre as respostas de atividade estrogênica determinada por um bioensaio e as concentrações de compostos encontradas por análises químicas dentro de uma ordem de grandeza que os tornem comparáveis entre si (RUTISHAUSER et al., 2004). As técnicas são distintas e cada uma tem suas vantagens e limitações, porém a combinação delas propicia a avaliação mais completa da presença dos compostos (LEUSCH et al., 2014).

O objetivo dos bioensaios é quantificar efeitos de compostos biodisponíveis com atividade biológica específica capaz de atingir as células e promover nelas alguma modificação (SANSEVERINO et al., 2005; CLODE, 2006). Entre esses efeitos, alguns podem ser mais prevalentes do que outros para o mesmo composto. A amplitude da avaliação biológica de uma mesma amostra pode ser determinada por meio de uma série combinada de bioensaios, como de mutagenicidade, genotoxicidade, estrogenicidade, entre outros (ALTENBURGER et al., 2015).

Diversos interferentes endócrinos, como aqueles representados anteriormente nas Figura 1 e Figura 2, têm atividade estrogênica quantificada por bioensaio para determinar qual o potencial relativo a cada composto. O potencial de estrogenicidade é medido individualmente por meio de padrões puros do composto em concentração suficiente para causar efeito biológico em 50\% (EC50) das células ou organismos expostos. Para compostos de baixa potência, os quais não atingem o valor de EC50, é utilizado alternativamente o cálculo da potência pelo EC10, que representa 10\%, ou pelo EC20, de 20\%, da concentração máxima efetiva (SANSEVERINO et al., 2009).

A Figura 6 ilustra as variações do potencial estrogênico dos compostos que foram quantificados por Sanseverino et al., (2009) utilizando o mesmo bioensaio in vitro do presente estudo. A Figura 6 mostra que compostos como bisfenol-A, fenobarbital, DDT, DDE e a testosterona, entre outros, têm efeito estrogênico. Os potenciais entre si variam, porém são 
capazes de ativar o receptor- $\alpha$ estrogênico. O potencial estrogênico é maior para os compostos 17 $\alpha$-estradiol, dietilbestrol, p-nonilfenol, 4-hidroxi-tamoxifeno e estrona, assim, concentrações mínimas desses estrogênicos são suficientes para desencadear estrogenicidade.

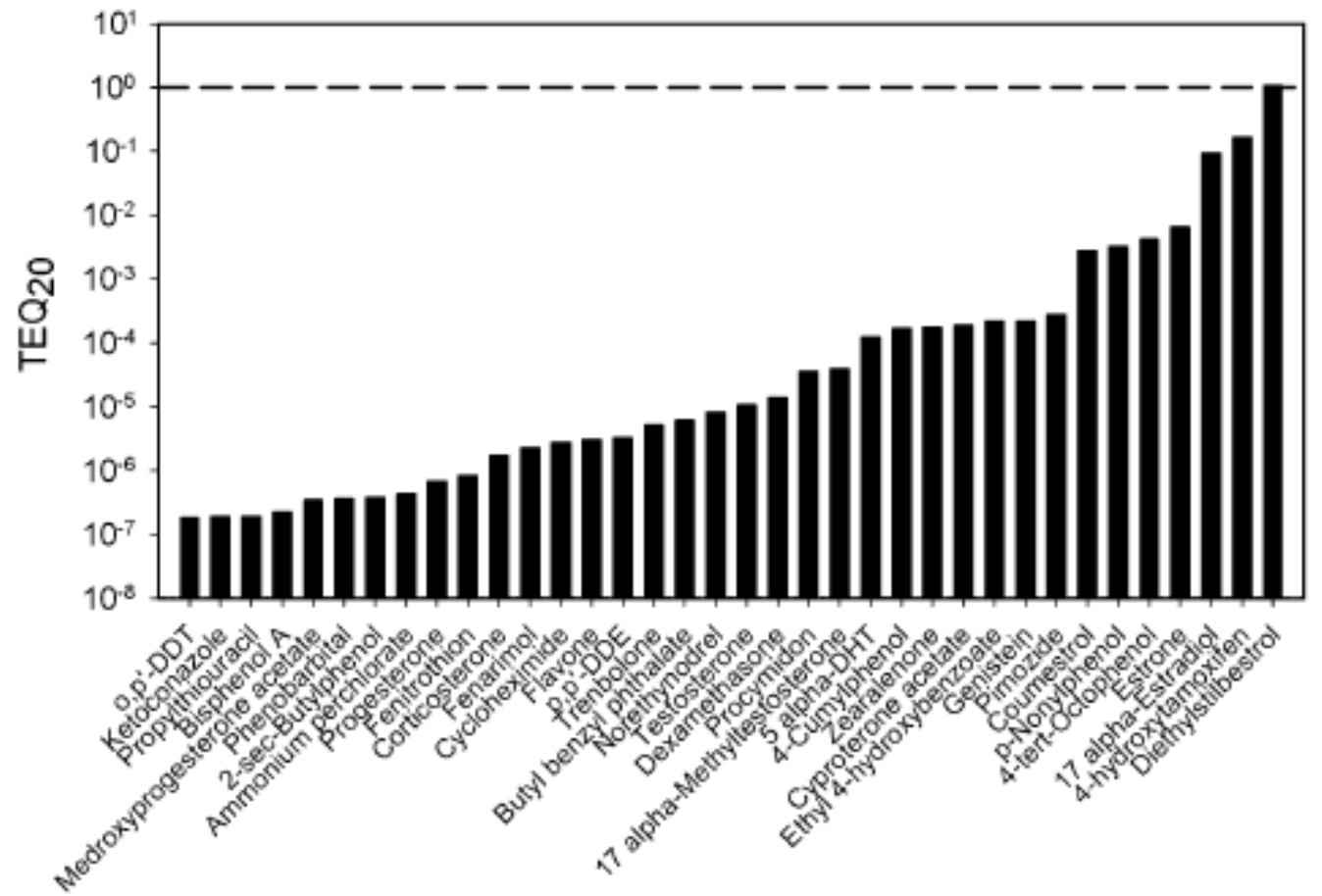

Figura 6 - Ordem de potencial estrogênico de compostos em $\mathrm{TEQ}_{20}$.

$\mathrm{O}_{\mathrm{TEQ}} 20$ é calculado dividindo o EC20 do padrão pelo EC20 do composto testado.

Fonte: Sanseverino et al. (2009).

Conforme indicado na Figura 6, os hormônios 17 $\alpha$-estradiol, dietilestilbestrol e estrona são evidenciados como os mais potentes; e seus efeitos estrogênicos em ambiente aquático já haviam sido descritos através de bioensaios in vivo em espécies de peixes tais como Oryzias latipes, Danio rerio e Oncorhynchus mykiss (FENSKE et al. 2005; METCALFE et al., 2001; VAN DEN BELT; VERHEYEN; WITTERS, 2003). Os resultados do estudo de Van Den Belt, Verheyen e Witters (2003) demonstraram que a estrona, mesmo em baixas concentrações, tem potencial de alterar a síntese de vitelogenina e causar inibição testicular em trutas (Oncorhynchus mykiss), porém o estradiol é ainda mais potente que a estrona (PANTER; THOMPSON; SUMPTER, 1998).

A atividade estrogênica é medida em bioensaios utilizando-se o $17 \beta$-estradiol como controle positivo, para estabelecer a curva de referência entre o efeito desse hormônio e o efeito de outros compostos ou mistura de amostras. Tanto em estudos in vivo como in vitro, o 
$17 \beta$-estradiol é usado em diferentes concentrações para medir o potencial estrogênico (METCALFE et al., 2001).

Com o propósito de determinar dos efeitos dos interferentes endócrinos, os bioensaios vem sendo empregados e têm aperfeiçoado a compreensão das misturas de compostos porque permitem detectar a atividade biológica de produtos estáveis, parcialmente degradados ou metabólitos (ESCHER; LEUSCH; 2012; DREWES et al., 2006). Podem ser divididos em dois grandes grupos: in vivo e in vitro, com desfechos ou conclusões diferentes entre si, que podem ser analisadas conjuntamente dependendo do grupo de compostos no ambiente pesquisado ou monitorado. Os bioensaios in vivo avaliam o efeito crônico relacionado ao tempo de exposição mais longo. Os bioensaios in vitro avaliam efeito biológico em tempo de exposição mais curto.

Estas técnicas e procedimentos são aplicados no biomonitoramento dos poluentes no ambiente, detectando concentrações muito baixas que podem não ser detectadas pelas análises químicas. Com a estratégia inicial da avaliação de atividade biológica de compostos por bioensaios, é possível monitorar o destino, controlar emissões de poluentes em pontos críticos de contaminação e avaliar sua extensão no meio ambiente por distintas vias de dispersão ou transporte (BEZBARUAH; KALITA, 2010; SOTO et al., 2006). Em um mesmo grupo de bioensaios, é possível observar diferenças de respostas biológicas porque os efeitos podem ser determinados por mecanismos de ação diversos, em decorrência de exposição mais longa ou pela mudança de resposta conforme a especificidade biensaio ou dos organismos utilizados no bioensaio (BERGMAN et al., 2013; YOST et al., 2015).

Os grupos de bioensaios são divididos em categorias e comumente há comparativos da potência dos compostos entre os bioensaios da mesma categoria, já que praticamente todos têm padronizado as medidas de estrogenicidade por 17 $\beta$-estradiol. Ou seja, o EC50 de um composto pode ser quantificado diferentemente conforme o bioensaio (LEUSCH et al., 2010).

Os bioensaios apresentam os resultados de atividade estrogênica em nanograma equivalente de $17 \beta$-estradiol por litro (ng-EEQ/L). Esse padrão compartilhado entre os bioensaios permite quantificar o efeito combinado de todos compostos presentes na misturas que possuem potencial de causar atividade estrogênica. As baixas concentrações de compostos isolados não determinariam os efeitos, mas é a interação entre eles que pode ser quantificada.

A seguir são descritos detalhadamente os modelos de ensaios in vivo e in vitro. 


\subsubsection{Bioensaios para estrogenicidade in vivo}

Os ensaios in vivo avaliam os efeitos em aspectos da fisiologia principalmente em organismos mamíferos e peixes com maior amplitude, como absorção, distribuição, metabolização, excreção, além de efeitos adversos e seus desfechos sistêmicos (BRAND et al., 2013). Estes aspectos de avaliação da fisiologia pela toxicologia cinética e dinâmica dos interferentes no sistema endócrino propiciam a maior interpretação à medida que se baseiam em exposição crônica e pode-se observar efeitos em cadeia (CLODE, 2006). Os resultados dos ensaios em ratos podem demorar de 28 a 90 dias, com testes parciais de ciclo de vida e estudos de epigenética transgeracional. Estes últimos têm sido utilizados para avaliar as mudanças genômicas transmitidas dos pais à prole em gerações de ratos e camundongos. Os testes propiciaram estabelecer a relação entre exposições a bisfenol-A e $17 \alpha$-etinilestradiol com mudanças na metilação de DNA (ácido desoxirribonucleico) e alterações na expressão gênica transmitida entre gerações (BHANDARI et al., 2014).

Os bioensaios in vivo demandam longo período de análise, maiores custos e espaço físico, envolvem questões de bioética e por isso não podem substituir testes in vitro para o biomonitoramento (MARTIN et al., 2007). Os testes in vivo atuais vêm sendo aprimorados para reduzir o tempo de resposta, utilizando-se para isso organismos em fase embrionária, de modo que os resultados possam ser observados mais precocemente e minimizar questões bioéticas, como as relacionadas ao uso de organismos adultos como peixes (Danio rerio, Oncorhynchus mykiss) ou mamíferos (ratos) em bioensaios (ESCHER; LEUSCH, 2012).

Entre os exemplos de bioensaios in vivo estão aqueles que avaliam as alterações fisiológicas em ratos machos e fêmeas, tais como o aumento de peso de órgãos reprodutivos e glândulas endócrinas, queratinização vaginal, mudanças hormonais, morfológicas e histopatológicas (SOLANO et al., 2015). Bioensaios completos avaliam os efeitos de diferentes concentrações de compostos em duas gerações de animais (CLODE, 2006). Já nos bioensaios realizados em peixes (Carassius auratos), geralmente são avaliadas a indução de vitelogenina e os efeitos associados a esta, como gônadas atrofiadas (SONG et al., 2013).

\subsubsection{Bioensaios para estrogenicidade in vitro}

Os ensaios in vitro são indicados para detectar atividade biológica de compostos porque são de aplicação mais simples, são miniaturizados e permitem avaliar maior número 
de amostras, já que suas respostas são determinadas em curto prazo. Os bioensaios possibilitam a rápida avaliação de qualidade das águas impactadas por efluentes ou misturas de compostos. Além disso, não envolvem questões bioéticas de uso de animais para fins experimentais (SOTO et al., 2006). Os bioensaios in vitro podem ser selecionados para avaliar a toxicidade de compostos específicos que se queira investigar conforme as prováveis fontes de contaminação que possam atingir as águas (ESCHER; LEUSCH, 2012).

Os ensaios in vitro selecionam os compostos que por afinidade tenham ligação com o receptor estrogênico da célula. Isso permite selecionar uma série de compostos prioritários que agem especificamente nos receptores provocando resposta aguda, porém com a desvantagem de não determinar os efeitos biológicos subsequentes (agonistas ou antagonistas) ou respostas sistêmicas determinadas pelos ensaios in vivo (CLODE, 2006). Além disso, bioensaios in vitro são capazes de identificar pequenas mudanças em nível molecular que provoquem uma ação biológica e amplificam as respostas que poderiam levar muito tempo para serem percebidas em um organismo completo.

Há vários ensaios utilizados na avaliação de potencial estrogênico em amostras ambientais. De modo abrangente, é possível definir três grupos capazes de fazer esse rastreamento (FANG et al., 2000), a serem apresentados a seguir.

\subsubsection{Receptor de estrógenos (ER) por ligação competitiva}

É um ensaio que por competição avalia afinidade do composto ao receptor, através de padrões de hormônios marcados radioativamente. Frequentemente, a marcação radioativa é feita no padrão 17ß-estradiol, que é usado como controle positivo, o qual se liga aos receptores. As amostras ambientais ou dos compostos estudados são preparadas com aumento gradativo de suas concentrações; menores concentrações do17 $\beta$-estradiol marcado indicam que o composto pesquisado ocupou o receptor que supostamente seria ocupado pelo $17 \beta$ estradiol marcado. Devido à maior afinidade do composto ao receptor ou porque a concentração do composto é maior do que a de $17 \beta$-estradiol.

\subsubsection{Ensaios de proliferação celular}

Ensaios de proliferação celular medem o aumento do número de células-alvo durante uma fase exponencial de proliferação celular (FANG et al., 2000). 
Os testes utilizam linhagens de células humanas de câncer de mama (MCF-7 ou T47D), nas quais é observado o crescimento celular na presença de compostos estrogênicos. Inoculam-se as células (MCF-7 ou T47-D) e comparam-se com controles negativos na presença de 17ß-estradiol (controle positivo), sendo possível avaliar compostos alvos em concentrações variadas, diferenciando-os em agonistas, agonistas parciais e compostos inativos. Um exemplo de bioensaio bastante utilizado é o E-Screen (LEUSCH et al., 2010), desenvolvido para detectar a indução e inibição causada por compostos estrogênicos em células proliferativas (SOTO et al., 1991).

2.4.3.2. Ensaio de gene repórter cuja ligação depende de atividade de transcrição e tradução

Estes ensaios analisam não apenas a capacidade do composto de se ligar ao receptor, mas também de expressar resposta. Os hormônios ligam-se aos receptores, atingem o núcleo das células, interagem com o elemento respondedor a estrógeno do gene alvo e transcrevem o mecanismo de ação (ROTROFF et al., 2014; SHEN et al., 2013; SOTO et al., 2006; WANG et al., 2013).

Os bioensaios anteriormente descritos foram comparados por Leusch et al. (2010), que concluíram que o teste de maior sensibilidade foi o ER-Calux (Estrogen Receptor Chemical Activated Luciferase Gene eXpression). O ensaio utiliza células humanas de câncer de mama com receptores alfa e beta (ER $\alpha$ e ER $\beta)$, que são mediados pelo gene repórter que contém três elementos de resposta estrogênica presentes na região promotora da enzima luciferase $\mathrm{O}$ receptor estrogênico ao ser ocupado por um composto estrogênico agonista ativa a proteína da luciferase, que é induzida pela lise celular na presença do substrato de luciferina e produz luz como sinal mensurável de resposta (LEGLER et al., 1999).

$\mathrm{Na}$ linha dos bioensaios de leveduras recombinantes, também estão o BMAEREluc/ER $\alpha$ (LESKINEN et al., 2005) e o bioensaio YES (Yeast Estrogen Screen). Este contém um gene receptor humano para estrógeno que, ao ser ativado, se expressa através do gene Lac-Z, o qual produz a enzima beta galactosidase, que metaboliza um substrato que pode ser medido por meio de método colorimétrico (BILA et al., 2007; FUTRAN FUHRMAN; TAL; ARNON, 2015; MARGOT et al., 2013; METCALFE et al., 2013; ROUTLEDGE; SUMPTER, 1996). 
Finalmente, entre os bioensaios de leveduras modificadas está o bioensaio BLYES (Bioluminescence Yeast Estrogen Screen), que será discutido detalhadamente na próxima seção e, cabe destacar, foi o ensaio empregado neste estudo.

\subsection{Avaliação de atividade estrogênica por técnica de BLYES}

O bioensaio de bioluminescência BLYES é um aprimoramento biotecnológico do teste colorimétrico conhecido como YES (ROUTLEDGE; SUMPTER, 1996). O bioensaio YES é um bioensaio que requer um substrato para revelar o efeito estrogênico. Na presença de estrógenos a $\beta$-galactosidade é sintetizada, secretada e que ao metabolizar o substrato clorofenol vermelho $\beta$-D-galactopiranosídeo mudando da cor amarela para vermelha. $\mathrm{O}$ bioensaio YES requer 3 dias para apresentar resultados colorimétricos (ROUTLEDGE; SUMPTER, 1996).

O BLYES foi desenvolvido a partir do mesmo mecanismo de receptor e transmissor de detecção de compostos estrogênicos do ensaio YES, com a principal vantagem da bioluminescência, baseada na ativação de genes bacterianos de Photorhabdus luminescens, que ativados produzem o substrato luciferina e a enzima luciferase (luc ou lux). O fato de não requerer adição de substrato representa menor tempo para obtenção dos resultados, menor limitação de número de amostras, menos manuseio de amostras e redução de custos. A reação de bioluminescência gera um sinal de luz visível que pode ser facilmente detectado por um luminômetro e quantificado em poucas horas (ELDRIDGE et al., 2015; SANSEVERINO et al., 2005). O BLYES é um bioensaio de estrogenicidade que tem sido aplicado mais reprodutibilidade e sensibilidade em diferentes tipos de amostras (ELDRIDGE et al. 2015, RUAN, et al., 2015; WANG et al., 2015). No Brasil, este bioensaio foi utilizado na avaliação estrogênica de águas superficiais e potável (BERGAMASCO, et al., 2011) e tem sido utilizado no biomonitoramento de águas superficiais e subterrâneas pela Cetesb (2013, 2014).

O bioensaio de BLYES faz uso da cepa de Sacharomyces cerevisiae a qual contém um receptor de estrogênio que é uma sequência de DNA humano (hER- $\alpha$ ) e um plasmídeo de base com elemento de resposta ao estrogênio (ERE)-lacZ que quando ativado reporta a ligação por sinal de bioluminescência. A levedura modificada tem seu crescimento controlado em meio de cultura pela inserção de dois marcadores, um de uracila e outro de leucina. Tratase de um controle seletivo que permite observar o crescimento apenas das cepas selecionadas 
para esse ensaio e prototróficas para uracila e leucina. Este controle interno na levedura permite assegurar somente o crescimento da linhagem geneticamente modificada.

Este bioensaio utiliza duas linhagens de leveduras: uma chamada BLYES, para detecção de estrogênios; e outra BLYR, uma linhagem bioluminescente que detecta os limites de níveis de toxicidade das amostras. Esse mecanismo de controle de toxicidade BLYR permite verificar que a linhagem de BLYES esteja ativa para resposta estrogênica. É usual aplicar um controle separado em bioensaios de resposta específica (ESCHER; LEUSCH, 2012).

No entanto, o ensaio BLYES tem a limitação de não diferenciar os estrógenos agonistas dos antagonistas (BERGAMASCO et al., 2011; FANG et al., 2000; SANSEVERINO et al., 2005). Esta limitação pode ser corrigida integrando um bioensaio androgênico. Isto porque geralmente os compostos androgênicos têm ação estrogênica e viceversa. O uso integrado de ambos possibilita quantificar a ação antiestrogênica, embora esta não seja uma prática observada na literatura (ESCHER; LEUSCH, 2012).

Outra limitação apresentada pelos ensaios de leveduras está relacionada à parede celular da levedura, que pode perder a seletividade e permeabilidade a alguns compostos, mas isso pode ser compensado pelas diluições seriadas de concentrações de compostos (LEUSCH et al., 2010; SANSEVERINO et al., 2005; SOTO et al., 2006).

Na pesquisa de desenvolvimento do bioensaio BLYES (SANSEVERINO et al., 2009) foram avaliados os potenciais estrogênicos individuais de 68 padrões de compostos. Os compostos analisados já possuía atividade estrogênica determinada em outros bioensaios reconhecidos pelo órgão norte-americano que regula os ensaios toxicológicos, o Interagency Coordinating Committee on the Validation of Alternative Methods (ICCVAM). No estudo de BLYES foram incluídos pesticidas, produtos farmacêuticos, esteroides, substâncias químicas intermediárias da indústria, plastificantes e reagentes analíticos para que o comitê pudesse validar o ensaio para esses compostos (SANSEVERINO et al., 2009). Os resultados publicados de atividade estrogênica demonstraram que o ensaio BLYES é comparável a outros ensaios (BMAEREluc/ER $\alpha$, yEGFP-S2, Luc-S2, bGal-S2, BJ3505,BJ-EC, YES) que utilizaram 17ß-estradiol como referência e S. cerevisiae (ELDRIDGE et al., 2015; SANSEVERINO et al., 2009).

Portanto, as vantagens já citadas como rapidez, economia, robustez, reprodutibilidade e sensibilidade contribuíram na escolha do uso do bioensaio BLYES para o presente estudo. Além dessas razões o bioensaio foi pouco estudado como instrumento de biomonitoramento de efeito estrogênico em amostras de esgotos. Apenas um estudo de Wang et al. (2015), 
utilizou o bioensaio BLYES em análises de esgotos em estações de tratamento de esgoto (ETE). Os resultados apresentados por estes autores indicaram o bioensaio BLYES pode ser aplicado no biomonitoramento de atividade estrogênica em ETEs com algumas vantagens (WANG et al., 2015).

A avaliação de atividade estrogênica em esgotos brutos e tratados por meio do bioensaio BLYES possibilitará estimar a atividade biológica acumulada nestas amostras ambientais e agregar resultados que são ainda escassos tanto pelo bioensaio BLYES quanto esse tipo de amostras. Os resultados destas análises podem complementar a compreensão de biomonitoramento em águas superficiais, subterrâneas e resultados de estudos de análises químicas para identificação e quantificação de compostos estrogênicos. 


\section{Objetivos}

\subsection{Objetivo geral}

Avaliar a atividade estrogênica utilizando o bioensaio BLYES em amostras de esgotos sanitários brutos e esgotos tratados, assim como em águas de reúso produzidas em ETEs localizadas na região metropolitana de São Paulo.

\subsection{Objetivos específicos}

- Quantificar a atividade estrogênica em esgotos brutos, tratados e águas de reúso de duas ETEs na região metropolitana de São Paulo.

- Comparar a eficiência dos processos de remoção da atividade estrogênica nas ETEs estudadas.

- Discutir as possibilidades e limitações do bioensaio BLYES na avaliação da atividade estrogênica em esgotos sanitários brutos e águas de reúso. 


\section{Metodologia}

\subsection{Atividades de campo: amostragem e coletas nas estações de tratamento de esgotos}

Para este estudo, foram selecionadas duas estações de tratamento de esgoto (ETE) da região metropolitana de São Paulo. As estações de tratamento de esgoto serão descritas como estação de tratamento de esgoto 1 (ETE-1) e estação de tratamento de esgoto 2 (ETE-2). Foram escolhidas essas estações porque ambas possuem tratamentos similares por sistema de tratamento de lodos ativados (biológico) e incluem tratamento por filtração (físico) e cloração (químico) para produção de águas de reúso para fins não potáveis e são utilizadas pelas indústrias, lavagem de ruas, irrigação de praças, etc. O sistema de lodos ativados, que é bastante difundido no país com grau de eficiência de $90 \%$ de remoção de carga orgânica, medida por demanda bioquímica de oxigênio (DBO). Deste modo, a avaliação de atividade estrogênica nas ETEs selecionadas permite obter resultados de um dos tratamentos mais utilizado no país e identificar eventuais diferenças entre as ETEs sob condições comparáveis.

As estações são semelhantes quanto aos processos de tratamentos, mas se diferenciam em dimensão: a ETE-1 tem capacidade para atender 720 mil habitantes, opera com vazão média de 0,8 mil litros por segundo e a extensão da rede de esgotamento é de $10 \mathrm{~km}$ de extensão; a ETE-2 tem capacidade para atender 1,4 milhão de habitantes, trabalha com vazão de 1,9 mil litros por segundo e os esgotos são transportados a uma extensão de $161 \mathrm{~km}$. (SABESP, 2014).

A ETE-1 localiza-se à margem do Rio Tietê, atende o extremo leste do município de São Paulo e parte de outras cidades próximas à região. Possui três pontos de entrada de esgotos, sendo um misto, que recebe esgoto doméstico e industrial, e os outros dois se caracterizam apenas como receptores de esgoto doméstico. Os três tipos de esgotos misturamse e recebem o mesmo tratamento. Este é realizado por sistema de lodos ativados em nível secundário.

Conforme o ponto 6 da Figura 7, observa-se que no tanque de aeração da ETE-1, há um compartimento separado para a câmara anóxica. As condições anóxicas da câmara propiciam que na ausência de oxigênio dissolvido o nitrato seja usado pela respiração de microorganismos facultativos e convertido em gás nitrogênio (SPERLING, 2007). 


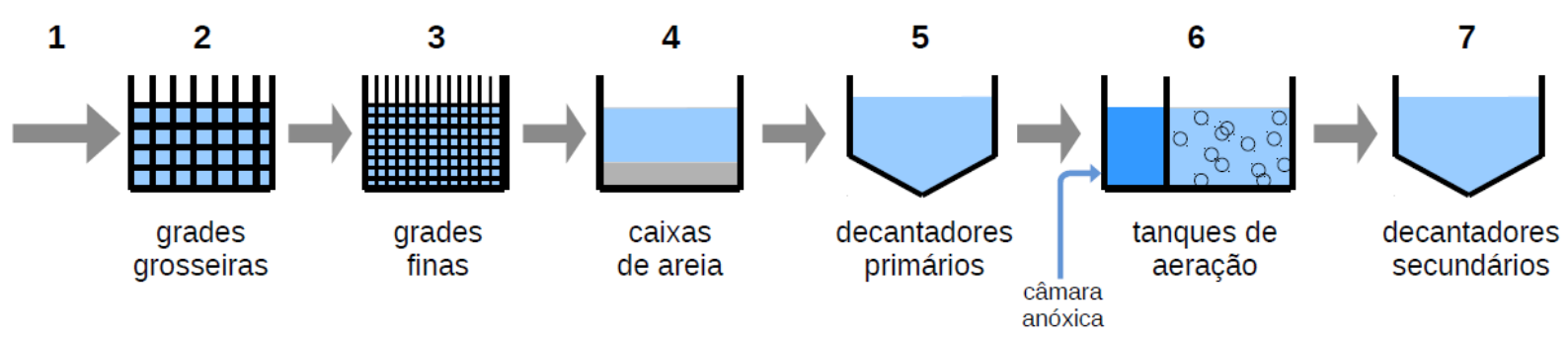

Figura 7 - Etapas dos processos de tratamento por sistema de lodos ativados da ETE 1.

Fonte: Adaptado de Sabesp (2014).

A ETE-2 localiza-se na zona sudeste do município de São Paulo, em região próxima que atende as cidades do pólo industrial, que em sua maioria são montadoras e empresas de serviços automobilísticos. A estação recebe tanto esgotos domésticos como efluentes industriais. O sistema de tratamento é por lodos ativados, como na ETE-1 (SABESP, 2015). Essa ETE possui dois pontos de recirculação de lodo. A ETE-2 possui os mesmos processos de tratamentos que a ETE-1, conforme a indicados pela numeração de 2 a 5 da Figura 7 , porém o tanque de aeração da ETE-2 não possui câmara anóxica.

Os esgotos brutos brutos das ETEs foram coletados no ponto 1 das ETEs conforme figura 7, ou seja imediatamente nas entradas de esgoto brutos sanitários.

As coletas em campo foram conduzidas por técnicos da CETESB, utilizando-se procedimentos padronizados de rotina para avaliação de qualidade de águas. Os locais dos pontos de coleta das amostras de esgoto bruto estavam nas entradas das estações em profundidade como poços, abaixo da superfície do piso e foram acessados através de tampas de aberturas. As coletas foram feitas com baldes coletores com capacidade de 3 litros, de inox polido presos a uma corda, com acesso à profundidade do poço de coleta. $\mathrm{O}$ volume coletado no balde foi transferido para o frasco de coleta de 1 litro; em seguida, medidos $\mathrm{pH}$ e temperatura da amostra.

As coletas de esgoto bruto foram no ponto anterior ao início do processo de tratamento. Não foi possível evitar interferências de contribuições de efluentes industriais, que podem eventualmente provocar alterações na composição do esgoto doméstico.

Amostras de esgoto sanitário bruto apresentam composição muito complexa pelas altas concentrações de compostos tóxicos, fato este que poderia limitar o uso da técnica de BLYES. Por outro lado, as amostras de esgotos tratados e de águas de reúso têm características comparáveis às águas superficiais que foram analisadas pelo bioensaio BLYES em estudos anteriores a este (CETESB, 2014; RAIMUNDO; 2011). 
Para evitar a mistura das águas de esgoto com águas de chuvas as coletas, foram realizadas coletas sempre em ausência de chuvas nas 24 horas que antecederam as coletas, conforme padronização (CETESB, 2012). A sazonalidade do período de chuvas não pôde ser observada porque ocorreram chuvas abaixo dos valores de anos anteriores e pouca variação de pluviosidade nos meses amostrados.

O esforço amostral do estudo ocorreu no ano de 2014 e a intensidade média anual de volume de chuvas foi de $1.055 \mathrm{~mm}$ no Estado de São Paulo, 26\% inferior à média histórica de 1438 mm medida dos últimos 19 anos conforme Figura 8. Entretanto, o esforço amostral do estudo não ocorreu nos meses de janeiro, fevereiro, junho e outubro que foram os meses de maior estiagem em relação à média histórica.

Os pontos de coleta de esgoto tratado por esses sistemas de lodos ativados foram feitos logo após o tratamento nos decantadores secundários, na etapa 7 na figura 7.

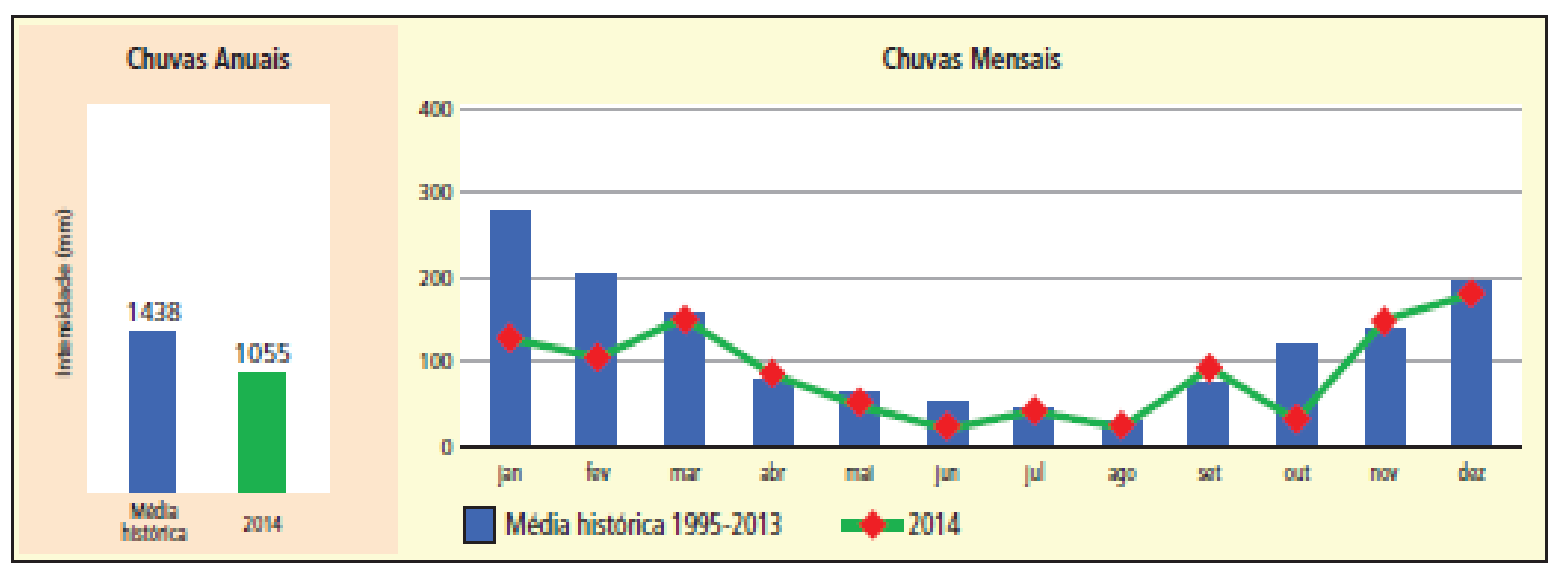

Figura 8 - Intensidades de chuvas mensais e anuais no Estado de São Paulo em 2014.

Fonte: Cetesb (2014).

Os últimos pontos de coletas foram para as águas de reúso geradas pelo tratamento por filtração e cloração na etapa final dentro das ETEs 1 e 2 (Figura 9). Uma parte dos esgotos tratados é encaminhada para o tratamento e produção de águas de reúso. O tratamento é iniciado pelo mecanismo de filtração, o qual é divido em uma etapa de filtração grosseira e outra de filtração fina. No sistema de filtração grosseira, as águas são bombeadas com vazão de $225 \mathrm{~L} / \mathrm{s}$ e passam por dois filtros de linha do tipo cesto em forma de cilindro, cada qual capaz de filtrar $800 \mathrm{~m}^{3} / \mathrm{h}$ e com grau de filtrabilidade de 250 micra de porosidade, sendo uma filtração mais grosseira que a microfiltração (diâmetro maior que 50 namômetros). A água produzida por esta primeira filtração grosseira, recebe a desinfecção por cloração é chamada 
água do tipo 1. A cloração é realizada por meio de dois cilindros e um injetor de cloro gasoso com capacidade de dosagem de 2000 libras/dia e 1500 libras/dia, respectivamente. Ao final da filtração grosseira com desinfeccção, a água tipo 1 é submetida a filtração fina, realizada em mais três etapas por meio de filtros de pressão de camada simples de areia e antracito. Estas águas recebem a correção de hipoclorito para manutenção da desinfecção e são chamadas de tipo 2 e foram analisadas neste estudo. A filtração em camada de areia mostrou ser uma etapa importante na remoção de interferentes endócrinos quando aplicada na finalização do tratamento foi utilizada após tratamento de ozonização e carvão ativado (MARGOT et al., 2013). A eficiência deste procedimento também é capaz de remover a remoção de atividade estrogênica quando empregada após tratamentos de lodos ativados (ESCHER et al., 2008).

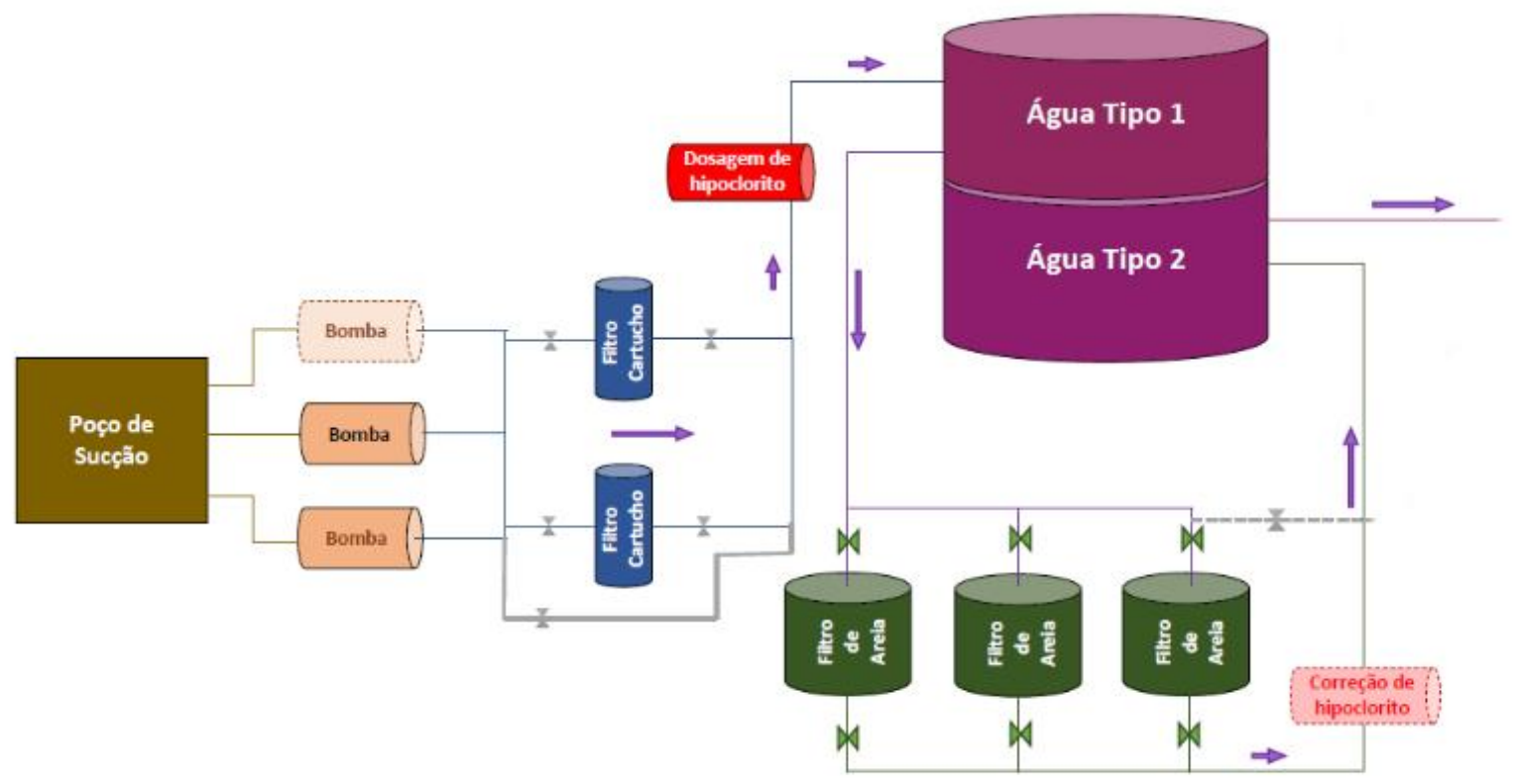

Figura 9 - Tratamentos por filtração e desinfecção nas ETEs 1 e 2 para produção de águas de reúso.

Fonte: Adaptado de Sabesp (2014).

As coletas nas ETEs 1 e 2 foram realizadas de março a setembro de 2014. A escolha dos pontos de amostragens pressupôs variações significativas entre as composições das amostras.

As coletas foram feitas nos três pontos correspondentes a cada tipo de amostra (esgoto bruto, esgoto tratado e água de reúso) de cada ETE, geralmente às segundas-feiras ou terçasfeiras, seguindo a agenda dos coletores e programação para preparo de amostras no dia 
seguinte no laboratório da Companhia Ambiental do Estado de São Paulo (CETESB). As coletas foram programadas para ocorrência no mesmo mês nas duas ETEs. Houve um esforço amostral para realizar as coletas nas duas ETEs no mesmo mês, organizado em ensaios de I a IV, agrupando-se a amostragem pela ordem cronológica dos meses. Isto ocorreu continuamente nos meses de março, abril e maio, indicados pelos ensaios de I a III. Entretanto, ocorreram separadamente em julho na ETE-2 e setembro na ETE-1 e os resultados foram agrupados como ensaio IV.

As amostras foram coletadas durante o dia, dentro do intervalo entre 9 horas e 17 horas. Esse procedimento está de acordo com resultados de Raimundo (2011), que não observou variações significativas de concentrações de interferentes endócrinos em águas superficiais em função do horário de coleta.

Os frascos de coleta utilizados eram de um litro, de vidro cor âmbar, de boca estreita, selados com papel alumínio entre a abertura do frasco e a tampa, para que não houvesse contato da amostra com o plástico da tampa. Os frascos passaram por limpeza especial, conforme recomendações do guia nacional de coletas e preservação de amostras (CETESB, 2012). Durante o transporte, as amostras foram preservadas em refrigeração com gelo e mantidas em temperatura de $2^{\circ}$ a $5^{\circ} \mathrm{C}$ e o tempo de deslocamento não excedeu 4 horas.

Após as coletas, observamos o prazo máximo de 24 horas para que as amostras fossem processadas, como forma de padronização para este estudo e de evitar efeitos mínimos de biodegradação microbiana (TERNES et al., 1999a).

Os procedimentos de coleta, medições, transporte das amostras dos esgotos tratados e águas de reúso foram iguais aos acima descrito para os esgotos sanitários brutos. Porém as coletas de esgotos tratados e águas de reúso puderam ser feitas nos pontos de saída por meio de mangueiras ou torneiras diretamente para os frascos de vidro de coleta. Na coleta, abriu-se a torneira, deixando o fluxo seguir por dois ou três minutos para limpeza de resíduos retidos na tubulação e, em seguida, foi realizada a coleta em fluxo contínuo até o preenchimento completo dos frascos.

Todos os procedimentos para amostragem seguiram recomendações do Guia Nacional de Coletas e Preservação de Amostras (CETESB, 2012). 


\subsection{Ensaios laboratoriais}

Os ensaios laboratoriais seguiram o protocolo do bioensaio BLYES de Sanseverino et al. (2009) e a preparação de amostras de Raimundo (2011) e Sodré et al. (2010). A preparação de amostras e a realização do bioensaio BLYES foram feitas nos laboratórios da CETESB, seguindo os padrões da norma ISO 17025.

No laboratório foi reservado o frasco de coleta utilizado como controle para cada ensaio, idêntico e preparado sob as mesmas condições de limpeza que os frascos utilizados das coletas de campo. O frasco controle foi preenchido no laboratório com água deionizada gerada pelo sistema Milli-Q e seguiu em procedimentos dos ensaios iguais aos das amostras.

A parte experimental de laboratório consistiu em três etapas, necessariamente na seguinte ordem:

- $\quad$ Filtração das amostras.

- $\quad$ SPE (condicionamento dos cartuchos, extração, eluição e concentração).

- Bioensaio BLYES.

\subsubsection{Filtração das amostras}

A avaliação do potencial estrogênico é feita em compostos solubilizados e disponíveis em água. Para isso, a filtração é uma das condições para análise (ALDA; BARCELÓ, 2001), bem como o volume das águas pesquisadas.

A metodologia adotada neste estudo avaliou os compostos de atividade estrogênica na fase dissolvida e incluiu a etapa de filtração, conforme resultados de estudos preliminares. De Desbrow et al.(1998), em análise com o bioensaio YES, detectaram que esses compostos não ficam retidos nas membranas. Huang e colaboradores (2001) avaliaram que a perda de hormônios, pela filtração e extração, é mínima (HUANG; SEDLAK, 2001). Para chegar a essa conclusão, as amostras de efluentes de ETEs foram fortificadas adicionando-se uma concentração padrão de 10ng/L de 17 $\beta$-estradiol e observaram a recuperação deste hormônio após o preparo. Os resultados obtidos foram de $99 \%$ de recuperação de $17 \beta$-estradiol após essas duas etapas de preparação de amostras. Raimundo (2011), em sua pesquisa com ensaio BLYES, comparou amostras de águas superficiais fortificadas filtradas e não filtradas e não observou diferenças na resposta de atividade estrogênica entre esses dois grupos. Na análise 
de esgotos brutos, tratados e águas de reúso das ETEs 1 e 2, as amostras foram preparadas do mesmo modo e no volume de 1 litro cada para evitar variáveis entre as amostras.

Antes da filtração, as amostras foram estabilizadas à temperatura ambiente e mantidas em repouso na bancada. Em seguida, todas as amostras e o controle (água Milli-Q) foram filtrados em membranas AP20, de fibras de vidro entrelaçadas e formando poros de tamanhos variáveis $(0,8-8 \mu \mathrm{m})$. Cada amostra filtrada foi recolhida separadamente em kitassato de vidro de capacidade superior ao volume da amostra (dois litros). Os respectivos frascos de coletas esvaziados foram levemente enxaguados com água gerada pelo sistema Milli-Q, e as amostras foram novamente devolvidas aos seus frascos correspondentes, para nova filtração em membrana de acetato de celulose de $0,45 \mu \mathrm{m}$ de porosidade. O produto dessa etapa foi a fração dissolvida da amostra.

Os acessórios de filtração e vidrarias foram preparados para a etapa acima descrita, tendo sido aquecidos à temperatura de $200^{\circ} \mathrm{C}$, e mantidos nesta temperatura por no mínimo doze horas.

A duração da filtração dependeu da presença ou não de material particulado nas amostras. Na preparação das 8 amostras de esgoto bruto do estudo, o tempo de filtração foi de aproximadamente seis horas, devido à elevada quantidade de material particulado. Já nas 8 amostras de esgoto tratado a filtração durou em média duas horas, e nas 8 amostras de água de reúso não chegou a uma hora.

\subsubsection{Etapa de extração de fase sólida - SPE}

A partir da fração dissolvida separada por filtração, foram extraídos os analitos por extração de fase sólida. Esta técnica é uma das mais usadas na separação e concentração de analitos semivoláteis e não voláteis ou sólidos extraídos dos meios nos quais se encontram a chamada fase móvel, que pode ser gás, fluido ou líquido. A fase sólida ou estacionária é assim chamada porque as amostras passam através de cartuchos ou discos que possibilitam o isolamento dos analitos. Os cartuchos e discos possuem variadas propriedades de adsorção e tamanhos conforme o tipo ou volume de amostra pesquisada. Também são usados solventes orgânicos (metanol, acetona, acetonitrila etc.) para condicionar a fase estacionária, funcionando como pré-tratamento para obter melhor superfície de contato com a solução aquosa (HUCK; BONN, 2000) para, posteriormente, eluir os analitos retidos na fase estacionária ou cartuchos. Esses solventes são escolhidos de acordo com as propriedades do cartucho e dos compostos a serem recuperados pela fase sólida. 
O cartucho utilizado para extração dos interferentes endócrinos foi o OASIS HLB, de 500mg, 6ml (Waters). Este cartucho tem capacidade extratora para volume de um litro de amostra e é indicado para extração de interferentes endócrinos em estruturas hidrofílicas e lipofílicas (LARA et al., 2009). O cartucho possui uma combinação de sorbentes copolímeros, com tamanho de poro de $80 \AA$ e tamanho de partícula de $30 \mu \mathrm{m}$, contendo dois compostos que permitem de forma sensível e seletiva reter simultaneamente compostos ácidos ou básico em amplo espectro de compostos. Sua estrutura lipofílica, um polímero de divinilbenzeno, permite a retenção do analito pela propriedade de fase reversa e a hidrofílica, um polímero de n-vinilpirrolidina, reduz o ângulo de contato com a água e permite a retenção dos compostos polares.

Os polímeros desse cartucho possuem macroporos que propiciam maior área de superfície de contato entre os analitos e o sorbente, o que favorece a capacidade de retenção. Os sorbentes desse cartucho têm superfície de área duas a três vezes superior aos cartuchos de sílica e retêm analitos polares nos poros após a secagem da amostra (POOLE, 2003).

Durante a extração não foram utilizados ajustes de $\mathrm{pH}$ para separação de grupos específicos de compostos porque o cartucho desempenha boa extração de compostos ácidos, neutros e básicos com uma ampla faixa de $\mathrm{pH}$. Outra razão foi que o ensaio BLYES é utilizado como screening ou biomonitoramento e o objetivo era de identificar a maior amplitude de interferentes endócrinos com atividade estrogênica.

\subsubsection{Condicionamento de cartuchos}

Os cartuchos foram encaixados no sistema de manifold e condicionados em $6 \mathrm{ml}$ de metanol (grau HPLC) por quinze minutos. O metanol foi o solvente escolhido para remover todos os compostos, conforme anteriormente empregado por Sanseverino et al. (2009). Nesse processo, foi controlado também qualquer tipo de contato com plástico ou materiais de contaminação. Esse procedimento removeu eventuais agentes residuais aderidos ao cartucho e preparou os sítios ativos para retenção dos compostos de interesse.

O fluxo de passagem das amostras através dos cartuchos foi controlado e mantido constante para assegurar a retenção dos analitos presentes na amostra. As amostras passaram pelos respectivos cartuchos identificados de acordo com a numeração interna da Cetesb, registrada nos frascos e fichas de coleta para cada amostra. O tempo determinado para a passagem do material foi controlado na velocidade de $10 \mathrm{ml}$ por minuto, observado como um 
gotejamento rápido. A amostra remanescente no cartucho foi secada com fluxo de nitrogênio de baixa intensidade para que toda parte líquida da amostra fosse eliminada, seguindo recomendações de Sodré et al. (2010).

\subsubsection{Eluição das amostras}

As lavagens e eluições são procedimentos seletivos para a separação dos compostos. A eluição interrompe o mecanismo de ligação do analito (força eletrostática) com a superfície adsorvente do cartucho ou disco (LISKA, 2000).

O cartucho utilizado foi de fase reversa, o qual retém analitos orgânicos do meio aquoso, pela forte atração das ligações de carbono-hidrogênio no analito e nos grupos funcionais da superfície (sílica). Para eluir os compostos adsorvidos no cartucho, foi utilizado o metanol por ser um solvente não polar que rompe a força de ligação desse empacotamento (POOLE, 2003).

Os compostos das amostras retidos nos cartuchos foram eluídos em metanol, para dessorção e arraste dos compostos junto ao solvente. Novamente, o fluxo de passagem deste eluente foi controlado por gotejamento mais lento. A amostra eluída foi recolhida em tubo do modelo de cintilação $(20 \mathrm{~mL})$ com tampa de rosca (SODRÉ et al., 2010).

\subsubsection{Concentração de amostras}

O volume de $6 \mathrm{ml}$ de amostra foi obtido pela eluição em metanol e posteriormente foi concentrado em sistema concentrador automatizado (Genevac). Os tubos de ensaio foram posicionados na base, equilibrando-se o balanço dos pesos dos tubos no rotor de centrífuga, mantidos abertos para a secagem e concentração. Selecionou-se a programação para compostos de baixa polaridade, que progressivamente gerou vácuo, elevou a pressão (12 MBar) e promoveu a retirada dos vapores de solventes; simultaneamente, aqueceu-se a base que, indiretamente, aquece os tubos das amostras. A temperatura atingiu $40^{\circ} \mathrm{C}$ através de uma lâmpada, e as amostras foram centrifugadas no concentrador.

Os compostos de interesse ficaram depositados no fundo e os demais foram volatizados juntamente com o metanol. A duração da concentração foi variada, mas o ciclo pôde ser programado por aproximadamente 45 minutos dependendo dos tipos de amostras. 
Os volumes remanescentes foram transferidos, por pipeta Pasteur, para os frascos menores de cromatografia de $2 \mathrm{~mL}$ com tampa com septo. O procedimento de lavagem com metanol foi realizado para retirada de todo concentrado eventualmente retido nos tubos e nas canaletas.

A etapa de concentração finaliza o preparo de amostras e o concentrado de $1 \mathrm{~mL}$, obtido a partir de 1 litro de amostra, é o produto final com o fator de concentração de mil vezes.

\subsubsection{Etapa do bioensaio}

Esta etapa englobou principalmente os processos de:

- $\quad$ preparo do meio de cultura;

- $\quad$ crescimento das linhagens de Saccharomyces cerevisiae;

- $\quad$ diluições de padrão de $17 \beta$-estradiol e de amostras;

- $\quad$ curva padrão e de amostras;

- $\quad$ análise de dados.

O bioensaio BLYES utilizado neste estudo foi desenvolvido por Sanseverino et al. (2005) e os procedimentos de análise seguem o protocolo desse mesmo autor (SANSEVERINO et al., 2009; SANSEVERINO et al., 2005).

\subsubsection{Preparo do meio de cultura}

Para o crescimento das linhagens de Saccharomyces cerevisiae, o meio de cultura utilizado foi o chamado "meio base para levedura" (YMM - Yeast Minimum Media). Esse meio de cultura está descrito em Routledge e Sumpter (1996). O meio de base a pH 7,1 foi preparado com a adição de 13,61 g de $\mathrm{KH}_{2} \mathrm{PO}_{4}$, 1,98 g $\left(\mathrm{NH}_{4}\right)_{2} \mathrm{SO}_{4}$, 4,2 $\mathrm{g} \mathrm{KOH}, 0,2$ g MgSO 4 , $1 \mathrm{~mL}$ de solução de $\mathrm{Fe}_{2}\left(\mathrm{SO}_{4}\right)$ de $40 \mathrm{mg}$ em $50 \mathrm{~mL}$ de água e $100 \mathrm{mg} \mathrm{L}$ de ácido glutâmico.

O meio de base para levedura foi preparado em 1 litro de água deionizada e, após homogeneização, foi autoclavado a $121^{\circ} \mathrm{C}$ por 10 minutos. Depois da autoclavagem, foram adicionadas ao meio as soluções de aminoácidos (sem leucina e uracila). 
Separadamente, foi preparada a solução de vitaminas no volume de $500 \mathrm{~mL}$ de água ultrapura e adicionados aos itens descritos na tabela 3. A solução foi finalizada pela esterilização por filtração em membrana de acetato de $0,22 \mu \mathrm{m}$ e foi armazenada no refrigerador abaixo de $5^{\circ} \mathrm{C}$.

A preparação de $500 \mathrm{~mL}$ do chamado "meio de cultura para crescimento de Saccharomyces cerevisiae" (YMMG - Yeast Minimum Media Growth) foi feita com seis soluções (Tabela 3).

Tabela 3 - Soluções para preparo de meio de cultura para crescimento de levedura (YMMG).

\begin{tabular}{lll}
\hline $\begin{array}{l}\text { Componentes do meio } \\
\text { de cultura de crescimento }\end{array}$ & Concentrações & Volumes $(\mathbf{m L})$ \\
\hline $\begin{array}{l}\text { Meio mínimo base (YMM) } \\
\text { (sem leucina e uracila) }\end{array}$ & \\
Solução de vitaminas & $20 \%$ & 354,5 \\
Glicose & $4 \mathrm{mg} / \mathrm{L}$ & 10 \\
Ácido aspártico & $24 \mathrm{mg} / \mathrm{L}$ & 100 \\
Treonina & $0,345 \mathrm{mg} / 50 \mathrm{ml}(20 \mathrm{mM})$ & 25 \\
Sulfato de cobre (II) & & 8 \\
\end{tabular}

Fonte: Routledge e Sumpter (1996).

\subsubsection{Crescimento das linhagens de Saccharomyces cerevisiae}

As leveduras Saccharomyces cerevisiae modificadas utilizadas neste ensaio são prototróficas para uracila e leucina, e o meio de cultura de crescimento utilizado não possui esses dois aminoácidos, como modo de assegurar que o crescimento das leveduras corresponda à linhagem modificada.

As culturas de Saccharomyces cerevisiae BLYES e BLYR (controle de toxicidade) utilizadas foram importadas da universidade de Tennessee, EUA, onde foram desenvolvidas por engenharia genética. As culturas crescidas foram transportadas em placas de Petri até o laboratório local da CETESB, onde foram preparadas para armazenagem em ampolas de congelamento para estocagem em freezer a $-70^{\circ} \mathrm{C}$.

A partir da cultura de estoque descongelada $(1 \mathrm{~mL})$, as linhagens de leveduras foram incubadas em frascos de Erlenmeyer com capacidade de armazenamento para $250 \mathrm{~mL}$, com $30 \mathrm{~mL}$ de meio de cultura, tampado com papel alumínio em agitador na agitação de $250 \mathrm{rpm}$, a $30^{\circ} \mathrm{C}$, por aproximadamente 24 horas ou até que atingissem o crescimento medido pela 
densidade ótica de $<1$ em $600 \mathrm{~nm}\left(\mathrm{DO}_{600}\right)$, medida em uma cubeta de vidro pelo espectrofotômetro. Essa medida determinou o crescimento ideal para realização do ensaio.

\subsubsection{Diluições de padrão de $17 \beta$-estradiol e amostras}

O produto final das etapas que antecedem o bioensaio resultou no extrato das amostras (1 mL) com fator de concentração de mil vezes. Os compostos extraídos que estavam aderidos aos frascos (capacidade de $2 \mathrm{~mL}$ ), na etapa anterior foram solubilizados com dimetilsulfóxido (DMSO), que é um solvente orgânico menos tóxico para a Saccharomyces cerevisiae que o metanol. Foi necessário diluir o solvente orgânico em água deionizada ultrapura Milli-Q, para reduzir ainda mais sua toxicidade, e assim a amostra suspensa teve a concentração de DMSO a $10 \%$.

A solução de DMSO a 10\% de foi mantida como estoque, para posterior utilização no bioensaio junto com amostra na concentração de 4\%. Para cada ensaio, foram preparadas duas microplacas de Elisa (modelo de microplaca de imunoensaio heterogêneo) para as diluições seriadas das amostras. Uma das microplacas foi utilizada para a linhagem de BLYES e a outra para a linhagem BLYR. Os ensaios foram realizados nessas duplicatas de linhagens (BLYES e BLYR).

A Figura 10 representa as diluições da curva padrão, das amostras e dos controles nas microplacas. Em cada microplaca de BLYES e BLYR foi feito um controle positivo com 17ßestradiol e dois controles negativos (DMSO e meio de cultura). Nas mesmas microplacas, foram dosadas as amostras ambientais e a amostra controle com água Milli-Q. Os controles foram utilizados para assegurar a qualidade de limpeza da vidraria usada, avaliar o preparo das amostras e o meio de cultura.

A primeira etapa foi a amostragem da cultura de Saccharomyces cerevisiae nas microplacas. Pipetou-se $100 \mu \mathrm{L}$ da linhagem com meio de cultura para cada microplaca, utilizando uma pipeta multicanal. Em seguida, foi dosado $100 \mu \mathrm{L}$ de amostra diluída.

A fileira "A" da microplaca (Figura 10) foi reservada para o controle positivo com padrão de 17ß-estradiol em diluições seriadas em dimetilsulfóxido (DMSO). Esse controle foi o último a ser dosado para evitar qualquer tipo de contaminação cruzada. 


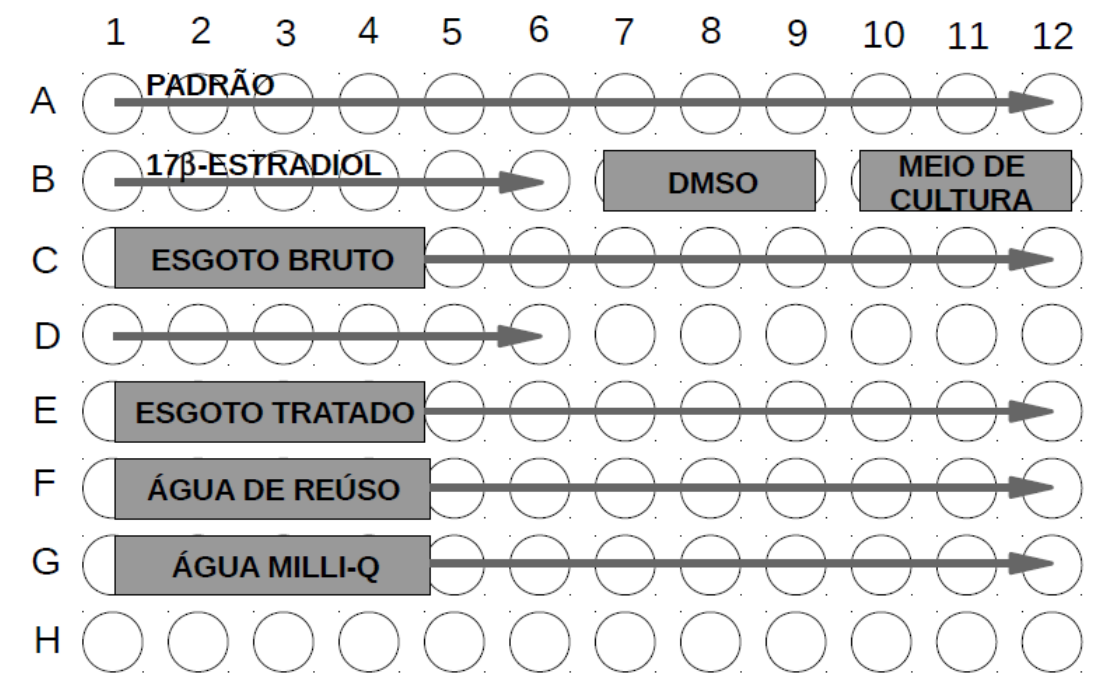

Figura 10 - Representação de microplaca modelo Elisa com modelo de marcação de diluições e controles utilizados para realizar o ensaio.

Fonte: Adaptado de Raimundo (2011).

A leitura das microplacas foi realizada em luminômetro (Victor X3), que contém o dispensador de reagentes Flex Drop Plus (Perkin Elmer).

Os extratos das amostras seguiram em dezoito diluições seriadas, que partiram da solução inicial das amostras concentrada de mil vezes para uma diluição anterior de cem vezes, antes das diluições seriadas (JARDIM et al., 2012).

As primeiras dosagens nas microplacas foram das culturas e controles negativos, nos micropoços nos volumes de $100 \mu \mathrm{L}$ por orifício. As microplacas foram agitadas em vórtex por 20 segundos e incubadas a $30^{\circ} \mathrm{C}$ por duas horas e meia.

\subsubsection{Curva padrão}

A série de diluições foi realizada com controle positivo de $17 \beta$-estradiol, para que fosse possível gerar uma curva padrão. A curva padrão foi utilizada para realizar equivalência entre as diluições de $17 \beta$-estradiol e as amostras estudadas, que também foram preparadas em diluições sequenciadas. Os pontos de diluições seriadas deram origem à curva esperada, isto é, a de forma sigmoidal conforme Figura 11.

A curva padrão foi feita com solução de $17 \beta$-estradiol $(272,39 \mathrm{~g} / \mathrm{mol})$ adicionando 13,6 mg em $5 \mathrm{~mL}$ de solvente (DMSO). Dessa solução padrão, obteve-se a maior concentração inicial de $1 \times 10^{-2} \mathrm{M}$. 
Para a curva padrão foi feitas 18 diluições seriadas em microplacas que iniciaram com $1 \times 10^{-5}$, atingindo a concentração final de $2,5 \times 10^{-12} \mathrm{M}$ de $17 \beta$-estradiol (E2) em $50 \mu \mathrm{L}$ de meio de crescimento de Saccharomyces cerevisiae (YMMG) com Saccharomyces cerevisiae crescida (Tabela 4).

Tabela 4 - Diluições do padrão $17 \beta$-estradiol nos vials.

\begin{tabular}{cccccc}
\hline \multicolumn{5}{c}{ Diluições seriadas para curva padrão } \\
\hline $1 \times 10^{-5}$ & $1 \times 10^{-6}$ & $1 \times 10^{-7}$ & $1 \times 10^{-8}$ & $1 \times 10^{-9}$ & $1 \times 10^{-10}$ \\
$5 \times 10^{-6}$ & $5 \times 10^{-7}$ & $5 \times 10^{-8}$ & $5 \times 10^{-9}$ & $5 \times 10^{-10}$ & $5 \times 10^{-11}$ \\
$2,5 \times 10^{-6}$ & $2,5 \times 10^{-7}$ & $2,5 \times 10^{-8}$ & $2,5 \times 10^{-9}$ & $2,5 \times 10^{-10}$ & $2,5 \times 10^{-12}$ \\
\hline
\end{tabular}

Fonte: Sanseverino et al. (2009).

A avaliação da atividade estrogênica por BLYES com padrão 17ß-estradiol em 18 diluições determinou os limites máximos e mínimos de detecção, que podem ser observados na figura 11 da curva padrão de 17ß-estradiol. A partir da curva sigmoidal padrão de 17ßestradiol foi determinado o valor de EC50. Este foi calculado pelos pontos centrais da porção de inclinação da curva sigmoidal para medir a atividade estrogênica da amostra (SANSEVERINO et al., 2009).

Na curva padrão sigmoidal que pode ser observada na figura 11, as doses mais baixas representam a resposta inicial em escala linear e com o aumento das concentrações e ativação biológica a resposta é em escala logarítmica. A partir do momento em que a resposta é induzida e forma a curva exponencial, no meio desta curva pode ser lida a EC50. As concentrações mais elevadas induzem à máxima resposta possível que aquela cultura de leveduras pode responder. Nas concentrações mais elevadas, a resposta é progressiva e geralmente em escala linear; por fim, as concentrações máximas não apresentam mais respostas ao atingirem o nível de saturação. 


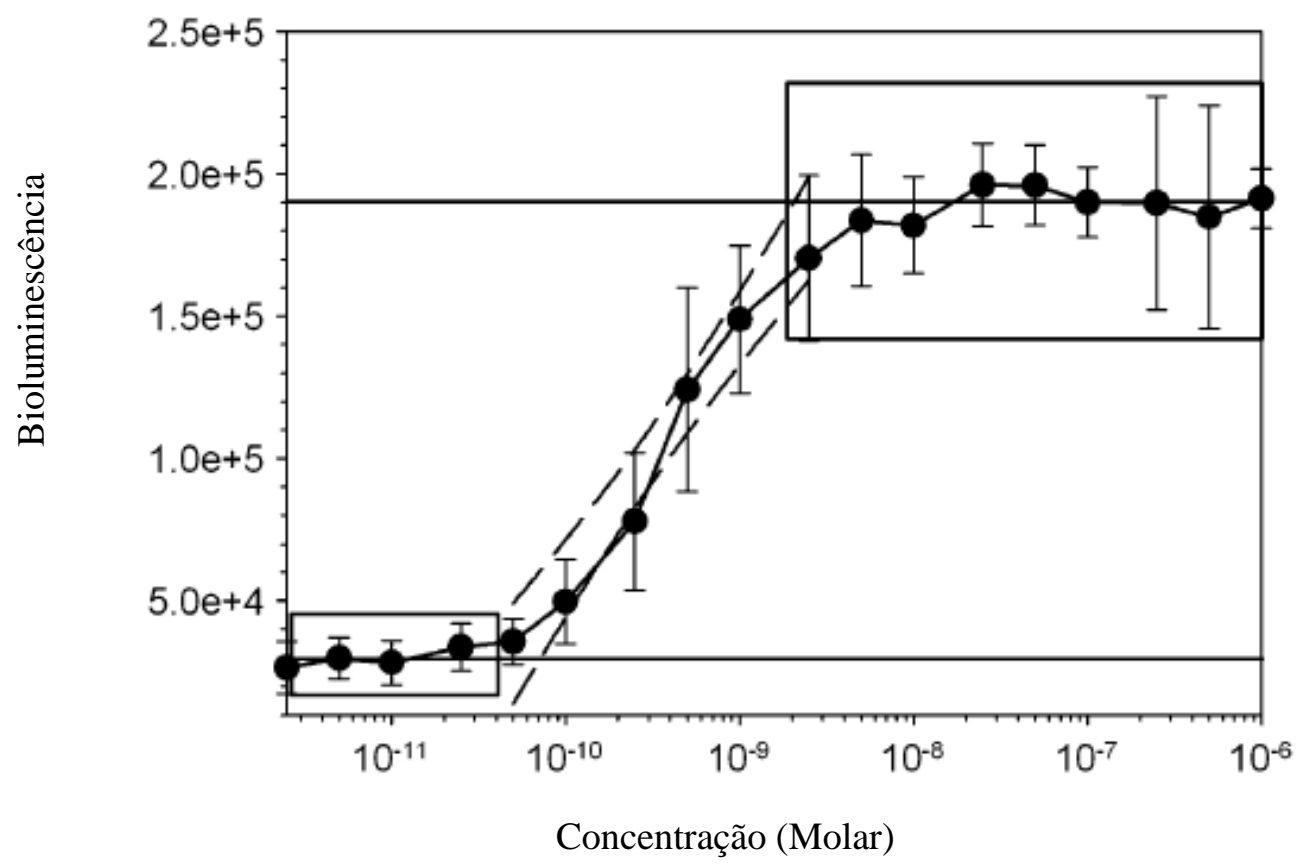

Figura 11 - Curva sigmoidal com padrão de 17ß-estradiol com levedura Saccharomyces cerevisiae no ensaio BLYES $(\mathrm{n}=18)$.

Fonte: Sanseverino et al. (2009).

Para medir o EC50, é necessário traçar uma linha entre três pontos, com apenas dois pontos não é possível determinar esse valor. O critério para aceitar o valor do EC50 do controle positivo é que o valor esteja entre 4,79 x $10^{-11}$ e $6,38 \times 10^{-10} \mathrm{M}$ de $17 \beta$-estradiol.

\subsubsection{Curva de amostras}

Para a quantificação da atividade estrogênica das amostras foram realizadas diluições seriadas semelhantes às realizadas com o padrão de 17ß-estradiol. As diluições seriadas de esgotos e águas de reúso foram adaptadas seguindo o modelo proposto por Sanseverino et al. (2009) e testado por Raimundo (2011) em amostras de águas superficiais. No presente estudo foram utilizadas até 18 diluições seriadas no caso do esgoto bruto.

Cada concentração gerou uma leitura de luminescência em um luminômetro, as quais foram posteriormente plotadas em gráfico. Os pontos do gráfico correspondentes ao padrão (17ß-estradiol) geraram uma curva modelo para a equivalência desta referência com os pontos das diluições das amostras. Cada concentração da amostra emite uma intensidade de luz de acordo com a quantidade de atividade estrogênica para aquele ponto de diluição. A intensidade de luz é medida pelo luminômetro e transformada em sinal numérico quantificado 
por um programa de informática acoplado ao equipamento que emite os dados. O programa sobrepõe a curva padrão e as curvas das amostras para encontrar similaridades entre os pontos. Esses pontos fornecidos pela curva padrão serviram para localizar onde se posicionaram as concentrações da amostra e determinar o seu grau de atividade estrogênica. Os cálculos têm como base as informações da série de referência do padrão de $17 \beta$-estradiol.

O bioensaio BLYES tem acreditação da coordenação geral de acreditação do Inmetro (CGCRE) e os procedimentos analíticos seguem os padrões laboratoriais internacionais da ISO 17025. Durante a realização dos ensaios, foram feitos controles negativos, para avaliação da vidraria, do meio de cultura e dos solventes e a ausência de resultado falso positivo habilitou as análises do estudo.

\subsubsection{Análise de dados}

Para calcular a concentração efetiva (EC50) da amostra, o valor foi determinado a partir do ponto do meio da porção linear da curva de dose resposta sigmoidal. Isso se a curva sigmoidal que estivesse presente fosse completa. Esses pontos do meio da curva estabeleceram os valores de máxima potência e eficácia em $50 \%$ das amostras. Com base nesses valores, foram calculados os valores de potencial estrogênico e concentração. Os resultados encontrados nas amostras foram avaliados conforme seus efeitos de estrogenicidade total relativos ao efeito de atividade estrogênica de 17ß-estradiol determinado na curva padrão. Os resultados foram expressos pela unidade de medida em nanogramas estradiol equivalente litro (ng-EEQ/L). O valor < 0,10 ng-EEQ/L representa o limite máximo de quantificação da sensibilidade do bioensaio BLYES.

Os compostos em contato com a levedura ativaram o receptor de estrógeno e foram emitidos sinais de bioluminescência. Esses sinais ópticos captados pelo luminônetro foram comparados aos sinais da curva padrão de 17ß-estradiol e os dados foram transmitidos para o computador. Por fim, os resultados foram calculados pelo programa sigma Plot. 


\section{Resultados e discussão}

Neste capítulo, são apresentados os resultados obtidos da atividade estrogênica avaliada pelo bioensaio BLYES em esgotos e águas de reúso de duas ETEs da região metropolitana de São Paulo. Os resultados das análises são discutidos em relação:

1. a avaliação de atividade estrogênica nas amostras antes e após os sistemas de tratamentos;

2. aos valores de remoção de atividade estrogênica entre as ETEs;

3. a avaliação do método de quantificação de atividade estrogênica utilizando bioensaio BLYES em esgotos e águas de reúso.

Os objetivos deste estudo foram quantificar a atividade estrogênica no esgoto bruto, no tratado e em águas de reúso, bem como avaliar a eficiência de remoção de atividade estrogênica nas duas ETEs e discutir as vantagens e limitações do bioensaio BLYES na avaliação de estrogenicidade destas águas. Os resultados de atividade estrogênica de 24 ensaios BLYES estão agrupados por fases denominadas I a IV. Essa sequência identifica os períodos cronológicos dos meses em que foram realizados os ensaios. As coletas foram feitas prioritariamente no mesmo dia nas duas ETEs e quando isso não foi possível, foram programadas saídas a campo adicionais em datas próximas, preferencialmente no mesmo mês. Conforme já apresentado no capítulo que trata da metodologia, foram feitas seis coletas ao longo de um período de sete meses, totalizando: quatro amostras de esgotos brutos, quatro de esgotos tratados e quatro de águas de reúso em cada ETE.

\subsection{Avaliação de atividade estrogênica nas ETEs}

\subsubsection{Esgoto Bruto}

As amostras de esgoto bruto foram coletadas antes do gradeamento grosseiro nas ETEs. A atividade estrogênica do esgoto bruto teve quantificações mais elevadas na ETE-1 que na ETE-2 com valores entre 14,7 a 52,6 ng-EEQ/L e 22,1 a 31,9 ng-EEQ/L, respectivamente (Tabela 5).

Foram observadas variações nos valores de atividade estrogênica entre os ensaios e entre ETEs. Os resultados foram quantificados em nanograma equivalente de 17ß-estradiol por litro (ng-EEQ/L) e na ETE-2 observou-se menor variação entre os valores. 
Tabela 5 - Esgoto bruto da ETE-1 e ETE-2. Resultados quantificados em ng-EEQ/L. Os números de I a IV representam os ensaios conforme períodos de amostragem.

\begin{tabular}{ccc}
\hline & \multicolumn{2}{c}{$\begin{array}{c}\text { Atividade estrogênica } \\
\text { (ng-EEQ/L) }\end{array}$} \\
Ensaios & ETE-1 & ETE-2 \\
\hline I & 14,7 & 24,4 \\
II & 33,9 & 22,1 \\
III & 52,6 & 31,9 \\
IV & 30,5 & 23,0 \\
\hline
\end{tabular}

A quantificação de atividade estrogênica está sujeita a interferências, dada a complexidade da composição do esgoto, da variabilidade temporal e dos fatores intervenientes decorrentes do processo de tratamento, sem descartar o potencial de interação dos compostos entre si. Conforme informações da empresa concessionária (SABESP), as ETEs estudadas recebem contribuições de origens diversas, tais como efluentes hospitalares e de processos industriais (indústria petroquímica, siderúrgica, têxtil etc.).

Os resultados observados em esgotos sanitários brutos permitem quantificar o efeito estrogênico, sem no entanto identificar quais compostos determinaram as respostas. $\mathrm{Na}$ composição de esgotos domésticos a estrogenicidade é prevalentemente ocasionada por hormônios naturais e sintéticos como $17 \beta$-estradiol e 17 $\alpha$-etinilestradiol, excretados na urina.

Gorga et al. (2014) e Salste et al. (2007), destacam que os hormônios estrogênicos contribuem com $80 \%$ da estrogenicidade dos esgotos domésticos e como possuem potencial estrogênico elevado, até mesmo baixas concentrações são suficientes para ativar as respostas por serem potentes. Desse modo, diferenças de concentrações desses compostos nas amostras justificam as oscilações nos resultados encontrados de estrogenicidade neste estudo.

Entretanto, os esgotos brutos estudados recebem a contribuição de esgotos industriais, hospitalares e outras fontes difusas, a mistura dessas fontes e oscilações em suas concentrações modificam os efeitos estrogênicos observados nas amostras, embora não se possa determinar a contribuição de cada fonte na mistura (GAULKE et al., 2009; HAMID; ESKICIOGLY, 2012; SILVA; OTERO; ESTEVES, 2012).

Os esgotos brutos estudados estão sujeitos à diversidade e variação de interferentes endócrinos contidos em produtos de higiene pessoal, limpeza e medicamentos (glucocorticoides, analgésicos, aditivos de medicamentos, siloxanos e parabenos). Além disso, mudanças decorrentes nos hábitos de consumo destes produtos podem afetar na atividade estrogênica. Isto em parte pode estar entre as razões que ocasionam as variações 
encontradas nos esgotos brutos das ETEs 1 e 2, conforme ponderam também outros autores (AVBERŠEK et al., 2013; GAVRILESCU et al., 2014; SUI et al., 2011). Há casos mais evidentemente associados à presença de dietil-meta-toluamida (DEET), utilizada na formulação de repelentes, que apresentou valor de concentração mínima de 124 ng/L no inverno; mas que, no verão, atingiu 1520 ng/L devido ao maior consumo sazonal (SUI et al., 2011). O DEET está entre o diverso grupo de compostos com potencial estrogênico e as diferenças em suas concentrações podem alterar a estrogenicidade das águas. As variações revelam que o consumo de produtos é um fator importante, embora variáveis temporais, espaciais que por sua vez estão associadas a fatores como taxas de produtivas e comércio de compostos, hábitos individuais de consumo de água, condições ambientais e de propriedades físico-químicas dos compostos também modifiquem as concentrações (LUO et al., 2014).

A avaliação de atividade estrogênica pode ser afetada pela presença de compostos de origem industrial (COLEMAN et al., 2008; FISCHER, 2013; RODA et al., 2006). A ETE-2 está localizada próxima a uma região mais industrializada (petroquímicas, siderúrgicas e têxtil) que a ETE-1. O ponto de coleta da ETE-2 recebeu a mistura de esgotos domésticos com efluentes industriais porque é o único ponto de entrada antes do início do tratamento, diferentemente do ponto de coleta da ETE-1 que recebe esgotos por três entradas, e a coleta, para este estudo foi feita no ponto que recebe esgoto predominantemente de origem doméstica.

Os efluentes industriais frequentemente apresentam compostos nonilfenóis, octilfenóis, bisfenóis (plastificantes), organosfosforados (pintura industrial, plástico e têxtil), parabenos (conservantes da indústria química) (ESTEBAN et al., 2014; JARSOVA et al., 2014; LINTELMANN et al., 2003; METCALFE et al., 2001) que têm atividade estrogênica e se misturam aos esgotos brutos. Enquanto os hormônios estrogênicos variam de 0,001 $\mu \mathrm{g} / \mathrm{L}$ a $0,8 \mu \mathrm{g} / \mathrm{L}$ a variação e concentração do surfactante nonilfenol por exemplo é de $<0,03 \mu / \mathrm{L}$ a $102 \mu \mathrm{g} / \mathrm{L}$ e por ter potencial estrogênico, é esperado que compostos como o nonilfenol tenham contribuído na atividade estrogênica, assim como outros compostos ocorrem em concentração abaixo de $1 \mu \mathrm{g} / \mathrm{L}$ (LUO et al., 2014).

Muitos compostos com atividade estrogênica ainda desconhecida podem ser coadjuvantes nos efeitos quantificados nos ensaios. Todos os interferentes endócrinos dos esgotos brutos foram capazes de ativar o receptor estrogênico e podem ter contribuído para os resultados observados das ETEs 1 e 2. A razão para isso é a afinidade desses com o receptor estrogênico da levedura utilizada no bioensaio BLYES (SANSEVERINO et al., 2009). Esse bioensaio é específico de estrogenicidade, porém o receptor de estrógeno da levedura do 
ensaio é pouco seletivo e os compostos menos estrogênicos também interagem no receptor. Desse modo, o ensaio propicia que todos interferentes estrogênicos que tem mecanismo de ação via ativação de receptor, sejam integrados na resposta.

Os resultados em esgotos brutos das ETEs 1 e 2 aproximam-se dos resultados da literatura obtidos com o bioensaio YES em esgotos brutos (COLEMAN et al., 2008; KIRK et al., 2002; MARGOT et al., 2013; ONDA et al., 2002; VERMEIRSSEN; SUTER; BURKHARDT-HOLM, 2006).

Os resultados desse estudo variaram no intervalo de 14,7 a 52,6ng-EEQ/L enquanto outros estudos apresentaram valores de atividade estrogênica em intervalos de 35,5 a 72ngEEq/L (ONDA et al. 2002) e 37 a 100ng-EEq/L (MARGOT et al., 2013). Portanto, nota-se que os valores obtidos por esses autores, assim como por Escher et al. (2008) de 91ng-EEq/L, superam o valor mais elevado deste estudo que ocorreu no ensaio III na ETE-1 de 52ngEEQ/L. O esforço amostral para esgoto bruto ocorreu nas ETEs 1 e 2 antes do tratamento por gradeamento, porém Margot et al. (2013) optou por coletas após o gradeamento fino $(1 \mathrm{~cm})$. Esses mesmos autores realizaram a filtração das amostras em membrana de porosidade de 0,7 $\mu \mathrm{m}$, enquanto outros autores empregam membrana de $1 \mu \mathrm{m}$ de porosidade (ESCHER et al., 2008). O protocolo da técnica de BLYES incluiu a etapa de filtração em membrana de fibra de vidro $(0,8$ a $8 \mu \mathrm{m})$ e posteriormente em membrana de acetato celulose $(0,45 \mu \mathrm{m})$, com o objetivo de reduzir o efeito citotóxico de compostos na levedura durante os ensaios, o que ocasionaria perda da medida do EC50 por redução no crescimento das leveduras ou lise celular (BISTAN; LOGAR; TISLER, 2011; COLEMAN et al., 2008; FISCHER et al., 2013). Apesar das variações metodológicas entre os estudos, os resultados de atividade estrogênica apresentaram níveis comparáveis entre as matrizes estudadas.

Outros autores complementaram a pesquisa de atividade estrogênica com identificação e quantificação dos compostos em esgotos brutos (MARGOT et al., 2013; ONDA et al., 2002). O hormônio 17ß-estradiol contribuiu com 54\% da atividade estrogênica total quantificada no esgoto bruto e, após o tratamento, a contribuição foi proporcionalmente superior a outros como nonilfenóis e bisfenóis, revelando que não houve remoção suficiente por tratamento em sistema de lodos ativados (ONDA et al., 2002). Onda et al.(2002) identificaram a contribuição dos compostos na atividade estrogênica, os quantificando por análises químicas e relacionando cada composto ao seu potencial estrogênico, para determinação teórica de seus EC50 em proporção ao EC50 total da amostra (ONDA et al., 2002). A identificação dos compostos que mais contribuem no todo da resposta estrogênica em esgoto bruto, serve para nortear quais as condições das ETEs e melhor ajustar condições e 
tecnologias para removê-los. A remoção de estrogênicos pode ser aprimorada combinando-se alternativas tecnológicas na ETE que complementam o tratamento, tais como a ozonização, os processos oxidativos avançados, a adsorção em carvão ativado, nanofiltração dentre outros (LUO et al., 2014; MARGOT et al., 2013; PRASSE et al., 2015).

A determinação da atividade estrogênica pelo método e ensaio BLYES no esgoto bruto foi atingida e os resultados permitiram a análise em relação à qualidade dos esgotos tratados das mesmas ETEs estudadas para a estrogenicidade.

\subsubsection{Eficiência de remoção de atividade estrogênica das ETEs 1 e 2 nos esgotos tratados.}

Na Figura 12, estão indicadas taxas de remoção de estrogenicidade nas ETEs 1 e 2 por tratamento biológico pelo sistema de lodos ativados, que gerou os esgotos tratados e posteriormente, o tratamento físico-químico dos esgotos tratados que gerou as águas de reúso. A ETE-1 apresentou os menores resultados de atividade estrogênica em esgotos tratados de 0,10ng-EEQ/L a 3,4ng-EEQ/L (Tabela 6) e as mais elevadas taxas de remoção entre 99\% e $89 \%$ no estudo (Figura 12).

O tratamento biológico por sistema de lodos ativados demonstrou em dados isolados deste estudo, a capacidade de gerar esgoto tratado com baixa atividade estrogênica em alguns ensaios. Esses resultados ocorreram na ETE-1 nos ensaios I e II, sendo que, no ensaio I, foi abaixo do limite de quantificação do método e no ensaio II foi quantificado 0,31 ng-EEQ/L (Tabela 6). 


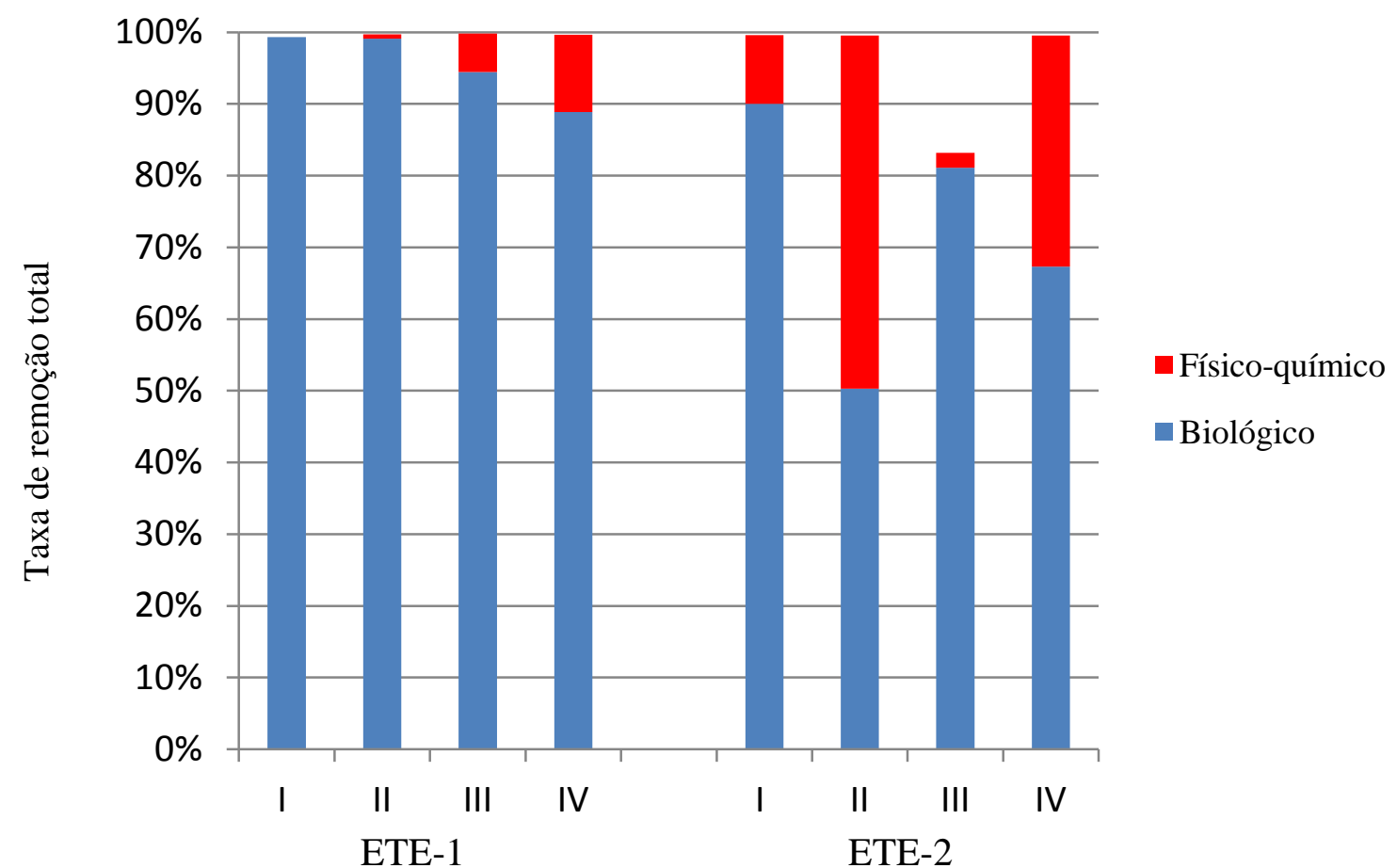

Figura 12 - Resultados de eficiência de remoção de estrogenicidade na ETE-1 e ETE-2, expressos em ng-EEQ/L, quantificado por BLYES. Os números de I a IV representam os ensaios conforme períodos de amostragem.

Os valores inferiores a 0,31ng-EEQ/L são indicativos de baixa atividade estrogênica no esgoto tratado e conferem maior proteção à vida aquática (Tabela 6). São valores que, na literatura, são considerados como residuais e que são obtidos em tratamentos por ozonização ou por ozonização combinada com cloração (DIAS et al., 2015; MARGOT et al., 2013). Os resultados de estrogenicidade não residual justificam precaução porque podem indicar a presença de compostos bioativos que permanecem após o tratamento e que são de mais difícil remoção pelo sistema de tratamento convencional (FUKUSHIMA et al., 2014; LIU et al., 2015; WATSON et al., 2012).

Tabela 6 - Resultados de atividade estrogênica de esgotos tratados das ETE-1 e ETE-2, expressos em ng-EEQ/L quantificado por BLYES.

Os números de I a IV representam os ensaios conforme períodos de amostragem.

\begin{tabular}{ccc}
\hline & \multicolumn{2}{c}{$\begin{array}{c}\text { Atividade estrogênica } \\
\text { (ng-EEQ/L) }\end{array}$} \\
Ensaios & ETE-1 & ETE-2 \\
\hline I & 0,1 & 2,44 \\
II & 0,31 & 11 \\
III & 2,93 & 6,02 \\
IV & 3,4 & 7,52 \\
\hline
\end{tabular}


A eficiência de remoção de atividade estrogênica apresentada nos ensaios II e III da ETE-1 e no ensaio I da ETE-2 foi em torno 90\% pelo tratamento biológico. Essa taxa de remoção está alinhada aos limites de biodegradação para estrogênicos, conforme argumentam diversos autores (JIANG; ZHOU; SHARMA, 2013; MICHAEL et al., 2015; TERNES et al., 1999a), indicando que os tratamentos por sistemas de lodos ativados removem aproximadamente $80 \%$ dos compostos estrogênicos, os quais podem permanecer inalterados ou gerar não conjugados que contribuem para a resposta estrogênica nos esgotos tratados (LUO et al. 2014). Os fatores associados à remoção serão discutidos posteriormente.

A eficiência do tratamento biológico em torno de $90 \%$ foi mais frequente nos ensaios na ETE-1, que gerou esgoto tratado com valores de atividade estrogênica próximo a 3ngEEQ/L. Outros estudos encontraram eficiência de remoção de atividade estrogênica acima de 90\% por sistema de lodos ativados (BRAGA et al., 2005; COLEMAN et al., 2008; LEUSCH et al., 2006). Embora não haja ainda normativas internacionais, os valores abaixo de 3ngEEQ/L podem servir como ponto de partida, dentro da capacidade de eficiência dos tratamentos atualmente disponíveis. Há autores que consideram esses valores como baixa estrogenicidade para essas águas (WATSON et al., 2012). Entretanto, há que se ponderar que o valor de atividade estrogênica de 2,44ng-EEQ/L (ensaio I) da ETE-2 pode causar maior impacto nos corpos hídricos receptores que os resultados de 2,93 e 3,4ng-EEQ/L (ensaios II e III) da ETE-1 (Tabela 6). A ETE-2 tem o dobro da vazão da ETE-1: $3,0 \mathrm{~m}^{3} / \mathrm{s}$ e $1,5 \mathrm{~m}^{3} / \mathrm{s}$, respectivamente. Esse fator afeta a capacidade de depuração nos rios e favorece a maior concentração nas águas, sedimentos e maior exposição à biota aquática aos riscos pela ETE-2.

Os resultados das ETEs 1 e 2 obtidos no presente estudo tiveram a atividade estrogênica removida nos ensaios com valores próximos a $80 \%$ pelo tratamento biológico em lodos ativados. A eficiência apresentada no estudo com valores de remoção igual ou inferior a $81 \%$ gerou esgoto tratado com atividade estrogênica em faixa mais elevada. Os resultados mais elevados ocorreram nos esgotos tratados da ETE-2. No ensaio II, da ETE-2 o valor de 11 ng-EEQ/L aproximou-se da atividade encontrada no esgoto bruto do ensaio I, da ETE-1 de 14,7ng-EEQ/L, embora seja um valor isolado entre os demais encontrados. Esse resultado alerta para os possíveis riscos à vida aquática, aumentando-se as chances de permanência dos compostos nas águas e transporte ao longo do rio.

De modo geral, a atividade estrogênica quantificada em esgotos tratados foi comparável aos valores encontrados na literatura com o ensaio YES, em ETEs de sistemas de lodos ativados (COLEMAN et al., 2008; ESCHER et al., 2008; KIRK et al., 2002). Os resultados do presente estudo variaram no intervalo entre <0,10ng-EEQ/L e 11ng-EEQ/L 
enquanto a literatura apontou os intervalos de: 0,7 a 8,3ng-EEQ/L (MARGOT et al., 2013), 1,5 a 3,9ng-EEQ/L (VERMEIRSSEN; SUTER; BURKHARDT-HOLM, 2006) e <1 a 12ngEEQ/L (HUGGETT et al., 2003). Note-se que os estudos utilizaram ensaio YES, porém Huggett et al. (2003) restringiram-se ao limite de quantificação de <1ng-EEQ/L valor este superior ao do presente estudo de <0,10ng-EEQ/L. O limite de quantificação deste estudo possibilitou análise com sensibilidade além da quantificada por Huggett et al. (2003) aumentando a amplitude de análise de atividade estrogênica inferiores. O limite de quantificação do teste é adequado para a classificação dessas águas. Os valores de atividade estrogênica tanto neste estudo como na literatura não ultrapassam 12ng-EEQ/L (COLEMAN et al., 2008; KIRK et al., 2002; LEUSCH et al., 2010; MARGOT et al., 2013).

Wang et al. (2015), avaliaram a estrogenicidade por meio do bioensaio BLYES esgotos submetidos ao tratamento por sistema de lodos ativados e bioreator de membrana. As análises de esgoto bruto apresentaram em média 29,82 ng-EEQ/L e após os tratamentos a estrogenicidade foi 10 vezes inferior no tratamento por bioreator de membrana com valor mediano de 0,32 ng-EEQ/L enquanto que o esgoto tratado por lodos ativados apresentou $3,25 \mathrm{ng}$-EEQ/L. O resultado de esgoto tratado por lodos ativados quantificado por Wang et al. (2015) é comparável ao resultado do presente estudo (WANG et al., 2015) e demonstrou ser menos eficiente na remoção que o tratamento por bioreator de membrana.

Na Figura 12, observamos os resultados de tratamento físico-químico aplicado no esgoto tratado para produção de águas de reúso. Em termos do sistema de produção de água de reúso pode-se dizer que nas ETEs 1 e 2 esses tratamentos geraram águas de reúso com atividade estrogênica abaixo do limite de quantificação de <0,10ng-EEQ/L e elevaram a eficiência de remoção a $100 \%$ na maioria dos ensaios realizados. O tratamento físico-químico associado após o tratamento biológico demonstrou boa capacidade de remoção empregando a filtração grosseira em filtros de 250 micra, cloração simultânea e, por último a filtração fina pressurizada por camada de areia e antracito (SABESP, 2014). Segundo resultados observados em outros estudos, a finalização do tratamento por filtração em camada de areia intensifica a remoção de compostos estrogênicos lipofílicos por sorção a este material (ESCHER et al., 2008; MARGOT et al., 2013).

O resultado observado no ensaio II da ETE-2 apresentou 50\% de eficiência no tratamento biológico e o tratamento físico-químico atingiu mais de 50\%. O único resultado de atividade estrogênica em água de reúso foi quantificado no ensaio III, da ETE-2, com 5,36 ngEEQ/L. Os resultados deste ensaio demonstram que a atividade estrogênica no esgoto bruto de 31ng-EEQ/L foi moderada quando comparada aos demais resultados dos ensaios e da 
literatura (ONDA et al., 2002; VERMEIRSSEN; SUTER; BURKHARDT-HOLM, 2006). Neste ensaio, os resultados de esgoto bruto foram indicativos da presença de compostos de remoção mais difícil observando-se ainda, que a remoção foi inferior entre os demais resultados obtidos pelo tratamento físico-químico.

Uma possível razão para o ocorrido talvez seja que a cloração tenha sido incompleta devido ao menor tempo de contato ou solução de cloro, associado às características de compostos presentes. Compostos como o bisfenol-A (BPA) são tem remoção inferior por cloração (LIU; KANJO; MIZUTANI, 2009) e sua presença ou a de interferentes mais persistentes a este tipo de tratamento como bezafibrato e dietil meta toluamida (SUI et al., 2011), além de outros podem ter gerado o resultado observado. A atividade estrogênica também pode ter sido por efeitos de subprodutos traços gerados pela cloração (METCALFE et al., 2013). Por fim, não se pode deixar de mencionar que o processo de filtração é fortemente dependente do tipo de filtro ou membrana (MICHAEL et al., 2015) e fatores como redução da vida útil do material ou passagem de compostos de tamanhos inferiores aos dos poros devem ser considerados.

Os resultados abaixo do limite de quantificação obtidos nas águas de reúso demonstram que a cloração foi efetiva na remoção da atividade estrogênica. A cloração é um processo de eficiente remoção de hormônios estrogênicos (SILVA; OTERO; ESTEVES, 2012). Os possíveis subprodutos da cloração não ativaram o receptor estrogênico e nem foram tóxicos às leveduras utilizadas no ensaio. Há autores que afirmam que o uso de bioensaios é efetivo para avaliação de águas com compostos transformados que encontram-se em concentrações de difícil detecção ou concentrações variáveis e misturas complexas (WATSON et al., 2012).

\subsubsection{Fatores relacionados à eficiência de remoção de hormônios estrogênicos em ETEs}

A remoção de compostos que causam atividade estrogênica depende de diversos fatores. Alguns estão relacionados às propriedades físico-químicas dos compostos, entre as quais podem ser citadas: a hidrofobicidade, a sorção, a biodegradabilidade, a biodisponibilidade entre outra. Uma segunda categoria de fatores reúne aqueles que dependem principalmente das condições operacionais das ETEs. Entre as condições está a maior idade do lodo, como fator principal na eficiência da remoção destes compostos (OGUNLAJA; PARKER, 2015; PETRIE et al., 2014). A seguir são discutidos os principais 
fatores relacionados à remoção de compostos estrogênicos nas etapas de tratamentos por sistema de lodos ativados.

\subsubsection{Tratamento Preliminar}

A redução da atividade estrogênica deve-se principalmente à remoção de compostos estrogênicos que mais contribuíram para os resultados de esgoto tratado das ETEs 1 e 2. Os interferentes endócrinos apresentam hidrofobicidade (coeficiente de partição octanol-água em $\left.\log \mathrm{K}_{\mathrm{ow}}\right)$ moderada $\left(2,50<\mathrm{K}_{\mathrm{ow}}<4\right)$ e alta $\left(>4 \mathrm{~K}_{\mathrm{ow}}\right)$ e coeficiente de partição $\left(\mathrm{K}_{\mathrm{d}}\right)$, que favorece sua remoção, conforme apresentado na seção de Introdução (Ocorrência e remoção de interferentes endócrinos em esgotos brutos nas ETEs) (BRANDT et al., 2013; KIDD et al., 2013; LUO et al., 2014). Essas propriedades foram determinantes na remoção dos compostos junto aos materiais sólidos em suspensão e lodos (LUO et al., 2014; BRANDT et al., 2013). O mecanismo de sorção ocorre desde o início do processo, no pré-tratamento nas ETEs 1 e 2 nas etapas de gradeamento, passagem por caixas de areia (figura 7 etapas 2, 3, 4 das ETEs 1 e 2). O mecanismo de sorção foi fundamental na remoção de compostos lipofílicos com atividade estrogênica.

\subsubsection{Tratamento Primário}

O mecanismo de sorção é decorrente da afinidade do composto com a matéria orgânica que constitui o lodo e este mecanismo ocorre nos processos de tratamento da ETE. A remoção de interferentes endócrinos por sorção nessas etapas corresponde aproximadamente a $10 \%$ da remoção total do processo de tratamento por lodos ativados (JOSS et al., 2004; MULLER et al., 2008; ZHOU et al. 2012), porém a sorção pode ser mais representativa para alguns interferentes endócrinos lipofílicos com $\log \mathrm{K}_{\mathrm{ow}}>4$ como nonilfenol (4,48 $\left.\log \mathrm{K}_{\mathrm{ow}}\right)$ e PCBs (5,62 a 7,75 $\left.\log \mathrm{K}_{\mathrm{ow}}\right)$, que são mais sujeitos à remoção por sorção ao lodo (BIRKETT; LESTER, 2003). O composto 17 $\alpha$-etinilestradiol, presumivelmente presente nas amostras deste estudo, tem o $\mathrm{K}_{\mathrm{ow}}=3,90$ (JOSS; TERNES, 2008) que favorece a sua sorção em matrizes sólidas e ao lodo (PETRIE et al., 2014). Os interferentes endócrinos foram removidos por sedimentação primária das ETEs 1 e 2 (Figura 7). 


\subsubsection{Tratamento Secundário}

Os estrógenos naturais como o $17 \beta$-estradiol, o $17 \alpha$-etinilestradiol e a estrona podem ser removidos na etapa do tratamento secundário (BIRKETT; LESTER 2003, ZHOU et al. 2010) (Figura 7, etapa 6 das ETEs 1 e 2). O mecanismo de biodegradação é a etapa mais importante do todo no processo de remoção, pois à medida que a biossorção é aumentada por meio da maior idade do lodo (decorrente de maior acúmulo deste no tanque de aeração) e do $\log$ de $\mathrm{K}_{\mathrm{ow}}$. Embora os interferentes endócrinos não sejam igualmente susceptíveis às mesmas taxas de biodegradação, os estudos em sistemas de lodos ativados indicam que no processo total de remoção de estrógenos $90 \%$ seja decorrente da biodegradação (ANDERSEN et al. 2003; BRAGA et al. 2005; SVENSON et al., 2003; ZHOU et al., 2012).

Entretanto as propriedades dos compostos podem ser modificadas durante os processos de tratamento, a exemplo do $17 \alpha$-etinilestradiol, que após a oxidação origina formas transformadas, mais hidrofílicas (VADER et al., 2000). De maneira semelhante, os hidrocarbonetos policíclicos aromáticos (PAHs), que são lipofílicos, tornam-se hidrofílicos à medida que perdem anéis aromáticos. Já o grupo de alquifenóis etoxilatos (aditivos plásticos, espermicidas etc.) quando degradados geram metabólitos hidrofóbicos como o p-nonilfenol (3,9 $\left.\log \mathrm{K}_{\mathrm{ow}}\right)$ e etoxilatos de p-nonilfenol $\left(5,99 \log \mathrm{K}_{\mathrm{ow}}\right)$. Esta dinâmica de reações durante o processo de tratamento origina compostos nos esgotos tratados diferentes dos compostos do esgoto bruto, mas que também podem apresentar algum grau de estrogenicidade. (LINTELMANN et al.,2003).

O suprimento de oxigênio dissolvido presente no meio aquoso e o tempo de contato mais longo entre os compostos e o lodo ativado são algumas das condições que favorecem a biodegradação por diferentes vias (aeróbia, anaeróbia e anóxica) nas ETEs (BIRKETT; LESTER, 2003; SILVA; OTERO; ESTEVES, 2012). A distribuição homogênea com boa capacidade de mistura dos compostos em meio aquoso também amplia o contato com o lodo ativado, rico em microrganismos, e consequentemente favorece a biodegradação. A biodegradação aeróbia é a principal via de biodegradação de interferentes endócrinos (ZHOU et al., 2010) e ocorre no tanque de aeração (Figura 7, etapa 6 das ETEs 1 e 2) no tratamento secundário. A maior idade do lodo favorece a biota de crescimento mais lento e a formação de flocos com maior superfície total para sorção.

A biodegradação pode ocorrer de modo intra ou extracelular e a sorção é um prérequisito para que isso ocorra. A propriedade química do composto influencia sua entrada na 
célula e determina a indução de enzimas intracelulares para degradação (BIRKETT; LESTER; 2003).

Segundo Petrie et al. (2014), o mecanismo para biodegradação extracelular dos compostos hidrofóbicos é mediado por enzimas bacterianas livres e ocorre dentro dos flocos formados por matriz extracelular. Presume-se que a degradação ocorra pelo aumento da capacidade de as bactérias utilizarem os estrógenos ou metabólitos como fonte de carbono e energia para o crescimento microbiano (PETRIE et al., 2014). A idade do lodo de até 10 dias parece exercer maior influência na remoção de compostos estrogênicos que períodos superiores a este (WANG et al., 2015). Conforme resultados observados por Wang et al. (2015), a remoção de atividade estrogênica em esgotos tratados por sistema de lodos ativados não pôde ser correlacionada aos parâmetros operacionais como demanda bioquímica de oxigênio, sólidos suspensos, tempo de detenção hidráulica e idade do lodo superior a 10 dias (WANG et al., 2015).

A biodegradação de compostos estrogênicos é intensificada pelo metabolismo cooperativo entre as bactérias heterotróficas e as bactérias que oxidam amônia como Nitrosomonas europea e Nitrosospira multiformis. No caso do $17 \alpha$-etinilestradiol, as bactérias que oxidam a amônia geram os metabólitos 4-OH-17 $\alpha$-etinilestradiol e sulfo- $\alpha$-etinilestradiol que são mineralizados pela ação da enzima dioxigenase das bactérias heterotróficas. O cometabolismo utiliza os metabólitos para o crescimento biológico dos microrganismos (GAULKE et al., 2008; KHUNJAR et al., 2011).

Alguns compostos são mais dificilmente degradados, como a estrona, que requer metabolização microbiana por diferentes vias utilizando múltiplos substratos e concentrações de carbonos orgânicos. Para que a estrona seja degrada é necessária maior diversidade microbiana, embora não tenham sido identificados quais os grupos microbianos responsáveis por sua degradação (TAN; ARNOLD; NOVAK, 2015). O hormônio sintético $17 \alpha-$ etinilestradiol é biodegradado mais lentamente que os demais compostos estrogênicos; sofre a ação catalisadora da enzima amônia monooxigenase, via hidroxilação e é convertido em produtos hidrofílicos não estrogênicos (SUAREZ; LEMA; OMIL, 2010). As bactérias isoladas em lodos capazes de biodegradar o 17 1 -etinilestradiol são Sphingobacterium sp, Rhodococcus zopfii e Rhodococcus equi, sendo que estas duas últimas degradam também 17 $\beta$-estradiol, estrona e estriol (CAJTHALIL et al., 2009; SILVA; OTERO; ESTEVES, 2012).

As propriedades dos compostos modificam-se na fase anóxica em relação à fase aeróbica (ZHOU et al., 2012). Isto ocorre porque os compostos tem cinética estimada pela 
constante de reação bioquímica, que varia na fase aeróbica e anóxica. Conforme indicam alguns autores, o 17 $\alpha$-etinilestradiol somente é transformado em condições aeróbicas e os estrógenos naturais podem ser transformados também em condições anóxicas (LUST et al., 2015; SUAREZ; LEMA; OMIL, 2010; ZHOU et al., 2012). Segundo Suarez, Lema e Omil (2010), o valor estimado da reação biológica para $17 \alpha$-etinilestradiol varia de 20 kio da fase aeróbica correspondendo a degradação no intervalo de 82 a $90 \%$ e na fase anóxica é de 0,4 $\mathrm{K}_{\text {bio }}$ atingindo menos de $26 \%$ de degradação. Em relação a estrona e o $17 \beta$-estradiol a degradação estimada é de $170 \mathrm{k}_{\text {bio }}$ na fase aeróbica, enquanto que na anóxica é aproximadamente de $3 \mathrm{k}_{\text {bio. }}$. Na fase anóxica o $17 \beta$-estradiol pode ser clivado e transformado de sua forma conjugada para a livre, porém à medida que a clivagem ultrapassa a taxa de biodegradação reduz-se a eficiência de remoção nesta fase. O aumento na idade do lodo exerce pouca influência na transformação dos estrógenos na fase anóxica (SUAREZ; LEMA; OMIL, 2010).

Os compostos 4n-nonilfenol e bisfenol têm menor sorção e a fase anóxica é importante em suas remoções podendo atingir valores de até $85 \%$ apesar do processo ser relativamente lento. Zhou et al. ( 2012), atribuem a degradação destes compostos à biodinâmica de pseudoprimeira ordem, em que a cinética de degradação estimada prioriza a degradação destes compostos quando em maior concentração (ZHOU, et al., 2012). Conforme Ogunlaja e Parker (2015), a biodegradação anóxica, é uma importante etapa na remoção de atividade estrogênica, porém de modo secundário em relação à aeróbica (OGUNLAJA; PARKER, 2015). Deste modo a fase anóxica pode ter removido compostos estrogênicos mais susceptíveis a este processo reduzindo os valores de estrogenicidade obtidos nos ensaios da ETE-1.

Em condições de suprimento de oxigênio dissolvido disponível, os compostos estrôgenicos dependem da propriedade de sorção $\left(K_{d}\right)$, que, por sua vez, é afetada pelas cargas positivas dos compostos e suas forças eletrostáticas com a superfície negativa da biomassa e influenciada pelas alterações de $\mathrm{pH}$. Os estrógenos têm coeficiente de sorção em digestores anaeróbios $<2,7 \mathrm{~K}_{\mathrm{d}}$ e supera esse valor em condições aeróbicas (AQUINO; BRANDT; CHERNICHARO, 2013).

No presente estudo a atividade estrogênica foi quantificada na fração líquida, porém à medida que os interferentes endócrinos são transferidos, em parte por sorção ao lodo, é esperado que muitos deles sejam removidos junto aos lodos das ETEs e não pelo processo de biodegradação na fase líquida. Ruan et al. (2015) quantificaram a atividade estrogênica nos lodos pelo bioensaio BLYES e obtiveram resultados de 2,8 a 4,7ng E2 $\mathrm{g}^{-1}$ em peso seco de 
lodo (RUAN et al., 2015). A identificação de estruturas moleculares do grupo de bisfenóis mostrou que permaneceram bioativos com intensidade estrogênica decrescente segundo a seguinte ordem: bisfenol AF, tetraclorobisfenol, bisfenol F, bisfenol A, bisfenol E, bisfenol S e 2,4-dihydroxibenzofenona, presentes em picogramas por grama de lodo seco (RUAN, et al., 2015). Os resultados destes estudos mostram que a diversidade química dos lodos é bastante complexa, mas que apesar disto foi possível empregar o bioensaio BLYES aumentando sua aplicabilidade para mais matrizes.

\subsubsection{Tratamento físico-químico}

O tratamento físico-químico para produção de águas de reúso empregado nas ETEs, assim como o tratamento por sistema de lodos ativados, não tem o objetivo de remoção de interferentes endócrinos, porém teve sua eficiência observada nos resultados das ETEs 1 e 2, por meio da associação de mecanismos ocorridos na filtração e cloração.

O tratamento por cloração das águas de reúso nas ETEs 1 e 2 visa sobretudo, a desinfecção para eliminação de patógenos, sendo uma etapa das etapas mais utilizadas na desinfecção, por ser econômica e efetiva ao manter a ação residual do cloro (SCHARZENBACH et al., 2010). O cloro livre mantém-se estável e interage nos compostos orgânicos estrogênicos resultando na remoção de atividade estrogênica observada (SILVA; OTERO; ESTEVES, 2012).

Apesar de a cloração ser potencialmente uma etapa importante na remoção de compostos estrogênicos, apresenta a desvantagem apontada por Fukushima et al. (2014) de gerar subprodutos tóxicos. Estes subprodutos apresentam toxicidade em análises de genotoxicidade (WATSON et al., 2012). Há alternativas para minimizar os efeitos dos subprodutos da cloração e de outros processos oxidativos por meio de tecnologias adicionais para o aprimoramento da qualidade destas águas.

Nas ETEs 1 e 2 a etapa de filtração por areia e antracito, têm capacidade limitada de remoção quando comparada a outras tecnologias de microfiltração ou nanofiltração. Isto porque a filtração fina em areia e antracito representa um processo mecânico que fisicamente retém as partículas maiores $(0,3$ a 1,7 mm) em comparação com outros métodos de filtração, como a microfiltração e nanofiltração e menor adsorção que o tratamento por carvão ativado (LUO et al., 2014; SPERLING; 2007). 
Ainda assim, o processo de filtração em camada fina de areia pode remover estrógenos. Ifelebuegu (2011) obteve resultados de remoção de compostos estrogênicos após a aplicação da filtração por camada de areia. A remoção de estrona, 17ß-estradiol e nonilfenol foi observada em valores de eficiência de remoção de até $30 \%$ de efetividade (IFELEBUEGU, 2011).

\subsubsection{Avaliação do bioensaio de BLYES em esgotos brutos e tratados}

Os ensaios tiveram a atividade estrogênica quantificada pelo bioensaio BLYES, e a toxicidade da amostra foi controlada pela linhagem BLYR. Esse controle serviu para monitorar que a toxicidade não foi superior à estrogenicidade do esgoto bruto de maneira a impedir a quantificação de atividade estrogênica. Desse modo, foram obtidos valores viáveis de atividade para cálculo do EC50, sem que houvesse inibição do crescimento ou lise da levedura, fator limitante principalmente pela complexidade de composição nos esgotos brutos. O critério para determinar o EC50 da amostra foi estabelecido no intervalo equivalente a 4,79 x $10^{-11}$ e $6,38 \times 10^{-10} \mathrm{M}$ de 17ß-estradiol (CETESB, 2014; RAIMUNDO, 2011). Os resultados das concentrações de amostras apresentaram-se nesse intervalo e em pontos alinhados, de modo a traçar uma reta entre eles e determinar o valor de EC50.

A composição dos esgotos brutos pode incluir compostos sabidamente tóxicos à levedura Saccharomyces cerevisiae utilizada, como os fungicidas (fenarimol) e inseticidas (fenitrotion), que impedem o crescimento celular da levedura. A figura 13 apresenta a curva de resposta de atividade estrogênica do ensaio I no esgoto bruto da ETE-1. Nesta curva estão os resultados de BLYES e o controle de toxicidade de BLYR. Os primeiros pontos representam a base da curva com resposta linear contínua e indicam as concentrações mais baixas as quais não foram suficientes para induzir a resposta. Posteriormente foi observado o início de resposta na qual os efeitos podem ser notados após a exposição às concentrações progressivas da amostra. A resposta linear viabilizou identificar o primeiro ponto de indução do efeito desde o início até a resposta máxima, conforme a figura 13.

A comparação entre as figuras 13 e 14 indica a diferença de atividade estrogênica dos esgotos brutos da ETE-1 e da ETE-2 no ensaio I. Na Figura 13, o início do efeito observado na curva ocorre mais tardiamente que o efeito observado na Figura 14. A resposta observada na Figura 14 indica que concentrações menores da ETE-2 em comparação com a ETE-1 são suficientes para determinar o início do efeito estrogênico. 


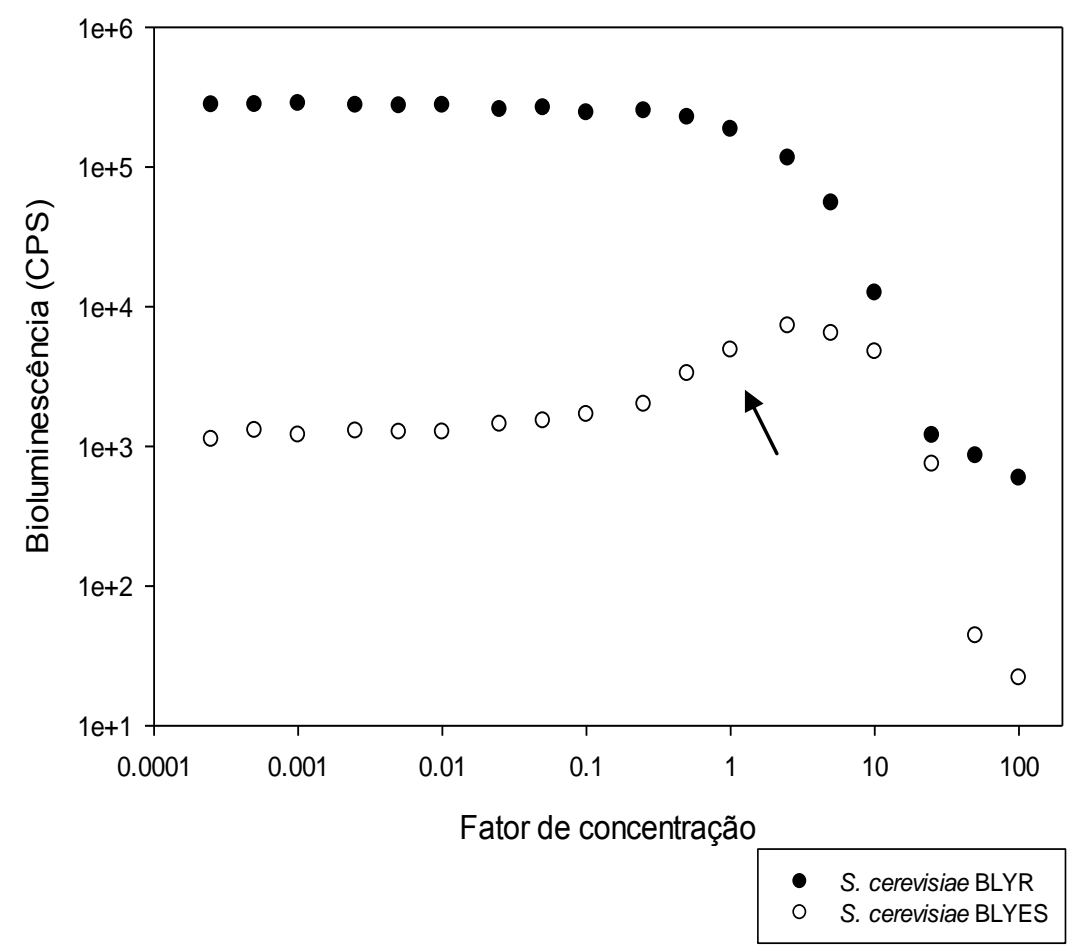

Figura 13 - Resultado de 14,7 ng-EEQ/L de atividade estrogênica de amostra de esgoto bruto da ETE 1, no ensaio I. A seta é indicativa de pontos de medida do EC50.

Na ETE-2 houve uma queda repentina na curva a partir do final da sua inclinação, demonstrando que a amostra foi estrogênica e tóxica em concentrações comparáveis (Figura 14).

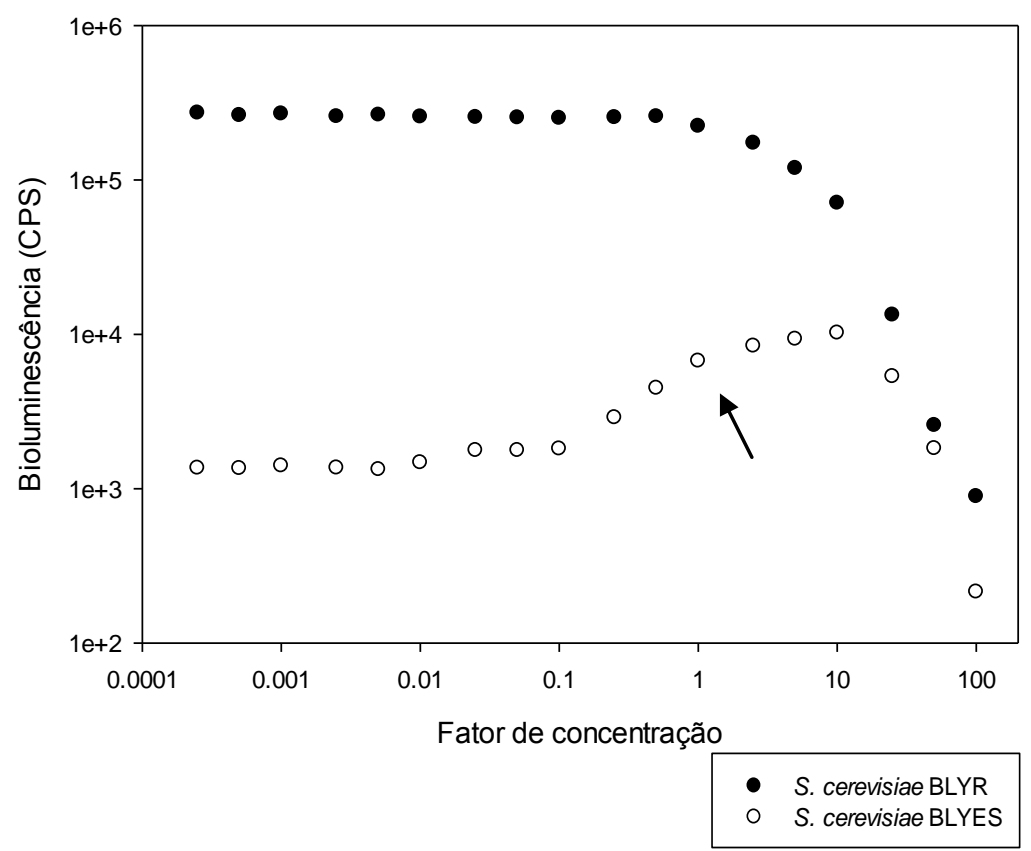

Figura 14 - Resultado de 24,4 ng-EEQ/L de atividade estrogênica de amostra de esgoto bruto da ETE 2, ensaio I. A seta é indicativa de pontos de medida do EC50. 
O bioensaio BLYES é principalmente indicado para o monitoramento inicial de atividade estrogênica em águas superficiais, subterrâneas e de consumo humano. Os resultados encontrados com valores acima dos limites de quantificação auxiliam na avaliação inicial e na posterior escolha de identificação por análises químicas dos prováveis poluentes de relevância ambiental. A sensibilidade e reprodutibilidade do bioensaio BLYES foi avaliada por Wang et al. (2015) de modo semicontínuo em esgotos brutos e tratados por lodos ativados e os resultados obtidos demonstraram rápida resposta com reprodutibilidade (WANG et al.,2015).

A quantificação de atividade estrogênica entre as etapas possibilita investigar diferenças de eficiência de remoção do efeito estrogênico e relacioná-las com as condições dos processos utilizados.

O resultado observado no ensaio II, na ETE-1 de 0,31ng-EEQ/L (Figura 15) expressa diferentes composições de amostras. A composição pode corresponder à resposta de inúmeros compostos ou formas não conjugadas de estrógenos livres ativos, que, pela interação sinérgica ou aditiva, apresentaram o efeito observado (ELDRIDGE et al., 2015; LIU et al., 2015; METCALFE et al., 2013).

A determinação de concentrações extremamente baixas exige técnicas de análises químicas bastante avançadas e, ainda que fossem determinadas as concentrações dos principais possíveis compostos presentes, permaneceria uma fração de atividade estrogênica correspondente a compostos desconhecidos (ESCHER; LEUSCH, 2012). Deste modo, os efeitos observados nos bioensaios como o BLYES ajudam a identificar, por análises químicas, compostos ainda desconhecidos, mas capazes de causar efeito. Isto ocorre porque ainda não são conhecidos os efeitos de todos compostos e nem todos os compostos encontrados em análises ambientais são identificados.

Uma estratégia utilizada é o emprego simultâneo e combinado de uma bateria de bioensaios conforme se suspeite da presença de compostos nas águas. Deste modo, elabora-se a estratégia de combinação de bioensaios que pode incluir um específico para estrógenos que quantifique um mecanismo de ação (BLYES), outro reativo (testes de genotoxicidade) e um de resposta não específica (crescimento celular) para que o desfecho entre os bioensaios apresente sobreposição de efeitos comuns associados a grupos de compostos. Assim, estimam-se primeiro os grupos de compostos associados a mais que um efeito; posteriormente, segue-se a etapa de análises químicas para identificá-los como prioritários. Entre esses podem ser identificados aqueles que não tinham ainda seus efeitos conhecidos (BRAND et al., 2013; ESCHER et al., 2014). 


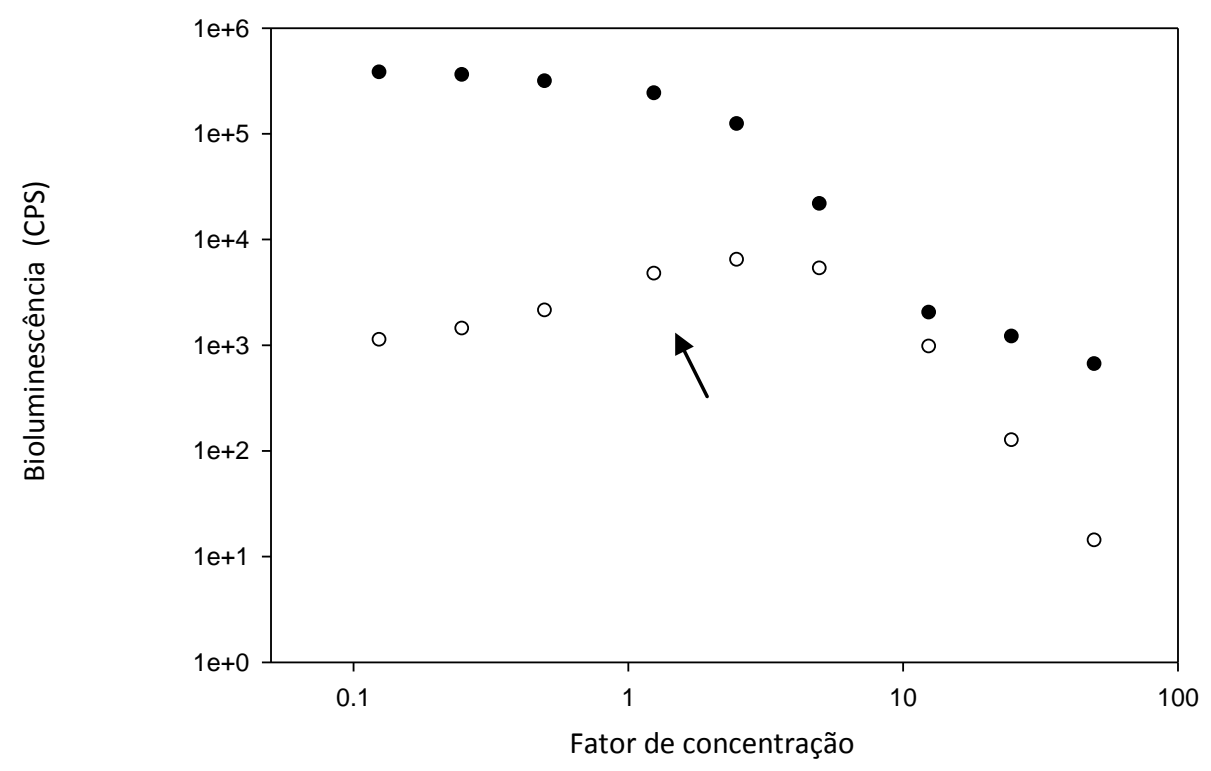

- S. cerevisiae BLYR

- S. cerevisiae BLYES

Figura 15 - Resultado de 0,31 ng-EEQ/L de atividade estrogênica do ensaio II, realizada em esgoto tratado na ETE 1. A seta é indicativa de pontos de medida do EC50.

A levedura apresentou-se bem sensível com limite de detecção do EC50 em 3,5 x 10 10 M/L de 17ß-estradiol. Esse limite de detecção conferiu sensibilidade adequada para as amostras testadas. Houve períodos em que a linhagem da levedura perdeu a sensibilidade e teve de ser substituída. As causas foram investigadas e não foram detectadas. Entretanto, por se tratar de um organismo geneticamente modificado, é provável que isto afete a capacidade replicativa da linhagem. Durante o período de pesquisa, uma nova levedura foi importada da Universidade do Tennessee, e os ensaios todos foram realizados com leveduras com a sensibilidade preconizada pelo método.

As linhagens de Saccharomyces cerevisiae utilizadas atingiram o crescimento suficiente para o bioensaio, medido pela densidade ótica de $<1$ em $600 \mathrm{~nm}\left(\mathrm{DO}_{600}\right)$. Dessa forma, a bioluminescência da linhagem propiciou a realização dos bioensaios porque em altas concentrações a toxicidade inibe a bioluminescência e há perda de sensibilidade. Houve ocasiões em que a levedura não apresentou crescimento satisfatório e os ensaios não foram realizados até que o crescimento fosse recuperado.

A etapa final do bioensaio BLYES é mais rápida que a etapa anterior do preparo de amostras. Isto porque a etapa de preparo de amostras requer o mesmo grau de pureza das 
análises químicas e cuidados com materiais utilizados. As amostras de esgoto bruto levaram maior tempo de filtração do que as demais.

Outros autores relataram dificuldades de análises de atividade estrogênica por meio do bioensaio YES (FISCHER et al., 2013; COLEMAN et al., 2008; RODA et al., 2006). Outros estudos mostraram que na análise de esgoto bruto com $15 \%$ de efluente industrial de sua composição inviabilizou a realização do bioensaio de quimioluminescência por levedura geneticamente modificada. Isso ocorreu porque os compostos de origem industrial provocaram perda de $60 \%$ do sinal de quimioluminescência da levedura e inviabilizou o bioensaio (RODA et al., 2006).

O bioensaio BLYES monitora os efeitos de interferentes endócrinos de mecanismo de ação agonista. A atividade estrogênica é mediada por outros mecanismos de ação, além da ativação do receptor de estrógenos, como é o caso dos ftalatos que agem na inibição de expressão gênica (FISHER et al., 2004). Portanto, para medir a atividade estrogênica completa seria necessário uma bateria de ensaios que considerassem o mecanismo de ação em função do tempo de exposição do interferente endócrino. Estas avaliações são bem mais específicas porque, a exemplo do ftalato, a ação pode ser transitória em determinada fase de desenvolvimento de organismos aquáticos.

\subsubsection{Destinação de esgotos brutos e tratados}

Os resultados obtidos da atividade estrogênica nos esgotos indicam a presença de interferentes endócrinos e os valores mostram a necessidades de melhorias nas condições de remoção destes compostos. As condições de tempo de detenção hidráulica e idade do lodo aumentam a eficiência dos sistemas de tratamento por lodos ativados na remoção de interferentes endócrinos, consequentemente cumprem a melhoria de outros parâmetros de qualidade físico-químicas do esgoto tratado final.

Os valores de estrogenicidade nas ETEs 1 e 2 evidenciam potenciais riscos aos corpos hídricos receptores, seja pelo lançamento de esgotos brutos ou por esgotos tratados. Há correlação de estrogenicidade em águas superficiais e de esgoto doméstico (ESTEBAN et al., 2014; ESCHER et al., 2008). A CETESB (2014) monitorou 35 pontos de amostragem em águas superficiais selecionados pelo Índice de Proteção à Vida Aquática (IVA) e foram detectados resultados de atividade estrogênica $>1 \mathrm{ng}-\mathrm{EEQ} / \mathrm{L}$ em nove pontos. Dentre esses 
pontos, 5 apresentaram atividade estrogênica > 5ng-EEQ/L quantificados por BLYES, alguns deles eram pontos de captação de água de abastecimento. Houve correlação moderada de atividade estrogênica com oxigênio dissolvido (OD), demanda bioquímica de oxigênio (DBO) e maior correlação com o Índice de Qualidade das Águas (IQA). Os resultados referem-se a pontos de localidades distintas expostas a fontes de contaminação de diferentes origens e com condições ambientais variadas. O cálculo do IQA considera nove variáveis de qualidade que ponderadas indicam o lançamento de esgotos sanitários mas, não trazem informações estrogenicidade na avaliação.

A estrogenicidade detectada em águas superficiais pode ter como origem o lançamento de esgotos brutos e esgotos tratados. As águas superficiais classificadas pelo Índice de proteção à Vida Aquática (IVA) foram monitoradas pela CETESB e em cinco pontos a atividade estrogênica foi quantificada acima de 5ng-EEQ/L (CETESB, 2014) valor este que supera os resultados detectados em esgotos tratados das ETEs-1 e 2 inferiores a 4ng-EEQ/L. Um dos pontos detectados foi o rio Piracicaba que sabidamente recebe esgotos tratados, indicando que o sistema de tratamento não removeu atividade estrogênica. Essa hipótese é condizente com níveis de atividade estrogênica encontrada nos rios: a) Atibaia de 0,13 a 0,33ng-EEQ/L; b) Sorocaba de 0,53 a 2,1ng-EEQ/L e c) Cotia de 0,35 a 8,7ng-EEQ/L (BERGAMASCO et al., 2011). Os resultados de atividade estrogênica do esgoto tratado da ETE-2 variaram no intervalo de 2,44ng-EEQ/L a 11ng-EEQ/L, valores esses que se aproximam aos do rio Cotia. Os rios Atibaia e Sorocaba tiveram resultados que são comparáveis ao rio Manzanares, de conhecida presença de interferentes endócrinos, no qual a estrogenicidade foi de 0,86ng-EEQ/L e 0,75ng-EEQ/L (ESTEBAN et al., 2014).

Assim, a estrogenicidade do esgoto tratados pelas ETEs 1 e 2 pode afetar as águas superficiais embora não hajam valores ainda regulamentados. Dessa forma, a efetiva redução de atividade estrogênica deve estar entre as metas dos sistemas de tratamento dos esgotos e a aplicação de bioensaios como BLYES viabiliza o monitoramento das fontes de estrogenicidade, além da estratégia de análise integrada nos mananciais.

A detecção de estrogenicidade em águas superficiais pode ser relacionada à presença de compostos estrogênicos sorvidos em sedimentos. Como visto anteriormente, os compostos estrogênicos têm coeficiente de sorção moderado, o que favorece que sejam sorvidos em material orgânico suspenso ou em sedimento. A ligação dos compostos depende da concentração de carbono $\left(\mathrm{K}_{\mathrm{oc}}\right)$ do material ao qual estão sorvidos. No entanto, a sorção moderada no sedimento não é linear porque há potencial biológico para biodegradação desses compostos para outras formas mais ou menos móveis ou solúveis. Caso sejam mais solúveis 
como a estrona e o $17 \beta$-estradiol (13ng/L) podem transportar-se ou para as águas superficiais ou para as águas subterrâneas. Compostos menos solúveis como o $17 \alpha$-etinilestradiol com 4,8 ng/L, são sorvidos no material sólido (REDDY; BROWNAWELL, 2005; CAMPBELL et al., 2006; YIN; KOOKANA; RU, 2002). Os compostos estrogênicos junto aos sedimentos podem ser transportados para águas subterrâneas conforme a permeabilidade dos solos, característica dos compostos e outros fatores (SCHWARZENBACH et al., 2010). Pode-se inferir que esgotos brutos ou tratados transportaram compostos de atividade estrogênica para um ponto do aquífero Guarani, no Estado de São Paulo, pois foram detectados valores de 0,11 e 0,38ngEEQ/L nestas águas (CETESB, 2013). Ainda que os resultados sejam de apenas duas ETEs, parece razoável considerar a importância de controle de estrogenicidade nos esgotos tratados haja vista a possibilidade de contaminação de reservas hídricas para fins de consumo humano.

Os resultados obtidos no presente estudo podem iniciar discussões sobre quais seriam os valores de referência de atividade estrogênica em esgotos tratados e águas superficiais. Os valores de atividade estrogênica em águas superficiais capazes de causar efeitos à biota aquática divergem entre os autores em 0,1 a 0,5 ng-EEQ/L (ESCHER et al. 2008; NELSON et al. 2007; PURDOM et al. 1994) e, em outros a partir de 1ng-EEQ/L (ESTEBAN et al., 2014). Embora os valores de atividade estrogênica não estejam normatizados em nenhum país conforme as classificações das águas, isso não impediria que o Brasil começasse as discussões de valores aceitáveis dentro de sua realidade. 


\section{Conclusões e considerações finais}

Neste trabalho foi avaliada a atividade estrogênica em esgotos urbanos, em virtude destes representarem uma das principais fontes de contaminação de recursos hídricos. Foram analisadas duas ETEs na região metropolitana de São Paulo, com objetivo de quantificar a atividade estrogênica em esgotos brutos, tratados e águas de reuso. $\mathrm{O}$ estudo também avaliou a viabilidade do ensaio BLYES para análise desse tipo de amostra. Com base no presente estudo e apoiada na bibliografia consultada é possível tecer as seguintes conclusões:

a) Sobre o tratamento de esgotos por sistema de lodos ativados

Os resultados confirmaram que a atividade estrogênica não pode ser completamente removida em esgotos tratados pelo sistema de lodos ativados. Esse sistema não foi originalmente desenvolvidos para remover interferentes endócrinos. Porém por intermédio dos resultados, observou-se que em alguns ensaios a atividade estrogênica foi reduzida a níveis próximo ao limite de detecção do bioensaio. Os possíveis fatores que favoreceram a maior remoção de atividade estrogênica em sistema de tratamento de esgotos podem estar associados às alterações de condições operacionais das ETEs, como no caso de maior idade do lodo e TDH, conforme relatado na literatura.

Foi observado que quando a eficiência de remoção de atividade estrogênica foi superior a $90 \%$ nas ETEs estudadas os esgotos tratados apresentaram estrogenicidade abaixo de 3,0 ng-EEQ/L.

Os resultados indicaram instabilidade na eficiência de remoção como provável consequência de oscilações nas condições operacionais e variações na composição estrogênica dos esgotos durante o período do estudo nas ETEs.

A queda na eficiência de remoção de compostos atividade estrogênica não está associada à estrogenicidade mais elevada dos esgotos brutos. Esta observação sugere que, apesar de alguns ensaios em esgoto bruto apresentarem maior estrogenicidade que outros, possivelmente os compostos presentes tiveram propriedades físico-químicas favoráveis à remoção ou que as condições operacionais da ETE, como tempo de 
detenção hidráulica ou maior idade do lodo, tenham sido favoráveis à maior eficiência de remoção.

b) Conclusões sobre o tratamento por filtração e cloração para produção de água de reúso

A fração dos esgotos previamente tratada por lodos ativados e destinada ao tratamento posterior por filtração e cloração gerou águas de reúso com atividade estrogênica abaixo de 0,10 ng-EEQ/L na maioria dos ensaios de ambas ETEs. Deste modo, o tratamento físico-químico posterior ao biológico elevou a eficiência total a $100 \%$ de remoção da atividade estrogênica nos ensaios em águas de reúso de acordo com o limite de quantificação do bioensaio BLYES. Estes resultados indicaram que a cloração não originou subprodutos de atividade estrogênica quantificáveis no limite de do bioensaio BLYES ou que, de outro modo, fossem tóxicos à levedura (controle BLYR). A eficiência do tratamento é relacionada a filtração em cartuchos e cloração, posteriormente aprimorada pela filtração por mais 3 vezes em camada fina de areia e antracito com correção da cloração.

\section{c) Conclusões sobre o bioensaio BLYES}

O bioensaio BLYES mostrou ser útil na quantificação de compostos estrogênicos em esgotos brutos, apesar da complexidade destas águas quanto à presença de diversos compostos e suas toxicidades. A análise de estrogenicidade nos esgotos brutos pelo método permitiu avaliar a eficiência dos tratamentos das duas ETEs estudadas. A metodologia no preparo das amostras e bioensaio permitiram as medidas do EC50 em todos ensaios.

Os resultados de atividade de estrogênica do bioensaio BLYES puderam ser comparados com os resultados da literatura com bioensaio YES. A similaridade entre eles mostrou valores comparáveis entre estudos em ETEs que operam com sistema de lodos ativados. Os resultados obtidos nas ETEs 1 e 2, acrescentam novos conhecimentos para discussão sobre contribuição dos esgotos na estrogenicidade em águas superficiais e subterrâneas. Como resultado, a integração de resultados de atividade estrogênica favorece o entendimento das fontes, ocorrências, destino, permanência e exposição a compostos estrogênicos nos ambientes aquáticos. 
Os resultados de baixa atividade estrogênica $(<3,4 n g-E E Q / L)$ podem expressar tanto a presença de estrógenos que permaneceram após o tratamento biológico como podem indicar que a atividade tenha ocorrido pela interação sinérgica de múltiplos metabólitos e subprodutos traços de baixíssima concentração. Estes resultados reforçam a relevância do biomonitoramento por bioensaios in vitro como BLYES porque auxiliam a posterior identificação por análises químicas da presença estrogênicos potentes ou a investigação de novos compostos estrogênicos em quantidades ultra-traços porém, com atividade biológica.

Este estudo quantificou a atividade de compostos estrogênicos que agem via receptor de estrógeno (agonistas), porém a avaliação completa estrogênica requer a inclusão de bioensaios de avaliação por outras vias mecanismos de ação. Estes bioensaios podem ser in vitro ou in vivo conforme o desfecho ou amplitude de resposta a ser investigada ou monitorada. Entretanto, o bioensaio BLYES cumpre a função de complementar biomonitoramento ambiental associado a outras técnicas. 


\subsection{Sugestões para estudos futuros}

Os resultados obtidos de atividade estrogênica em esgoto bruto representam a atividade estrogênica que chega às estações de tratamento de esgotos municipais. Esses resultados auxiliam a nortear as adaptações nas condições das ETEs quanto à remoção de atividade estrogênica e apoiar estratégias que contornem aumentos progressivos da carga de interferentes endócrinos nas ETEs de grandes conurbações.

Em termos de sugestões para estudos futuros, a partir dos resultados e conclusões deste estudo seriam:

Realizar a caracterização dos esgotos brutos e tratados através dos parâmetros físicoquímicos indicativos para a avaliação de biodegradação aeróbica da carga orgânica (DBO/DQO/COT), material sólido suspenso e associar resultados destes parâmetros à avaliação estrogênica, para melhor compreender a degradação dos interferentes endócrinos e sorção na fase sólida.

Determinar quais as etapas do tratamento por sistemas de lodos ativados, bem como tratamento físico-químico por cloração e filtração exercem maior influência na remoção de compostos de atividade estrogênica. A avaliação segmentada por etapa auxiliaria a compreender a relevância de cada uma delas no processo completo. Para esta avaliação, a atividade estrogênica poderia ser quantificada em esgotos tratados, lodos e nas etapas de produção de águas de reuso.

O uso do bioensaio BLYES integrado a outros bioensaios como de toxicidade inespecífica e ensaios de genotoxicidade podem auxiliar na identificação de compostos ainda desconhecidos, que tenham sobreposição de efeitos. A integração de bioensaios permitiria auxiliar na identificação de grupos de compostos semelhantes e que sejam de relevância ecológica.

Por fim, o acompanhamento dos resultados em período mais longo favoreceria a compreensão de interferências sazonais ambientais ou de consumo de produtos interferentes endócrinos. 


\section{Referências}

ALDA, K.; BARCELÓ, D. Review of analytical methods for the determination of estrogens and progestogens in wastewater. Fresenius Journal of Analytical Chemistry, v. 371, n. 4, p. 437-447, 1 out. 2001.

ALTENBURGER, R. et al. Future water quality monitoring - Adapting tools to deal with mixtures of pollutants in water resource management. Science of the Total Environment, v. 512-513, p. 540-551, 2015.

ANDERSEN, H. et al. Fate of estrogen in a municipal sewage treatment plant. Environmental science \& Technology, v. 37, n. 18, p. 4021-4026, 2003.

AQUINO, S. F.; BRANDT, E.; M. F., CHERNICHARO, C. A. Remoção de fármacos e desreguladores endócrinos em estações de tratamento de esgoto: revisão da literatura. Eng Sanit Ambient, v. 18, p. 187-204, 2013.

AVBERSEK , M. et al. Determination of estrogenic potential in wastewater without sample extraction. Journal of Hazardous Materials, v. 260, p. 527-533, 2013.

BARONTI, C. et al. Monitoring natural and synthetic estrogens at activated sludge sewage treatment plants and in a receiving river water. Environmental science \& Technology, v. 34, n. 24, p. 5059-5066, 2000.

BERGAMASCO, A. M. D. D. et al. Bioluminescent yeast estrogen assay (BLYES) as a sensitive tool to monitor surface and drinking water for estrogenicity. Journal Environmental Monitor, v.13, p. 3288-3293, 2011.

BERGMAN, A. et al. The impact of endocrine disruption: A consensus statement on the state of the science. Environmental Health Perspectives, v. 121, n. 4, p. 104-106, 2013.

BERNARDELLI, J. K. B. Biodegradação de estrona, 17ß-estradiol, 17 $\alpha$-etinilestradiol em sistemas aeróbios de tratamento. 2014. 197 f. Tese (Doutorado em Engenharia Ambiental), Programa de Pós-Graduação em Engenharia Ambiental, UFSC,Florianópolis, 2014.

BERNARDELLI, J. K. B. et al. Removal of estrogens by activated sludge under different conditions using batch experiments. Brazilian Journal of Chemical Engeneering, v. 32. n.02, p. 421-432, 2015.

BEZBARUAH, A. N.; KALITA, H. Sensors and biosensors for endocrine disrupting chemicals: State-of-the-art and future trends. In: Treatment of micropollutants in water and wastewater. Londres. IWA Publishing. p.93-128, 2010. 
BILA, D. et al. Estrogenic activity removal of $17 \beta$-estradiol by ozonization and identification of by-products. Chemosphere, v. 69, n.5, p. 736-46, out 2007.

BHANDARI, R. K. et al. Effects of the environmental estrogenic contaminants bisphenol A and $17 \alpha$-etinilestradiol on sexual development and adult behaviours in aquatic wildlife species. General and Comparative Endocrinology, v. 214, p. 195-219, 2014.

BIRKETT, J. W.; LESTER, J. N. Endocrine disrupters in wastewater and sludge treatment processes. IWA. 295p. 2003.

BISTAN, M.; LOGAR, R.; TISLER, T. Detection of estrogenic activity in Slovenian wastewaters by bioassays. Open Life Sciences, v. 6, n. 5, p. 829-837, 2011.

BRAND, W. et al. Trigger values for investigation of hormonal activity in drinking water and its sources using CALUX bioassays. Environment international, v. 55, p. 109-18, 2013.

BRANDT, E. M. F. et al. Behaviour of pharmaceuticals and endocrine disrupting chemicals in simplified sewage treatment systems. Journal of Environmental Management, v. 128, p. 718-726, 2013.

BRAGA, O. et al. Fate of steroid estrogens in Australian inland and coastal wastewater treatment plants. Environmental science \& Technology, v. 39, n. 9, p. 3351-3358, 2005.

CAJTHALIL, T. et al. Review: Microbial transformation of synthetic estrogen $17 \alpha-$ ethinylestradiol. Environmental Pollution. v. 157, p. 3325-335, 2009.

CAÑEDO, T. E. F., ÁlVAREZ, J. C. D., CISNEROS, B. J. The occurrence and distribution of a group of organic micropollutants in Mexico City's water sources. Science of the Total Environment, v. 454-455, p. 109-118, 2013.

CAMPBELL, C. G. et al. Biologically directed environmental monitoring, fate and transport of estrogenic endocrine disrupting compounds in water: A review. Chemosphere, v. 65, n.8, p. 1265-80, nov. 2006.

CETESB. Companhia Ambiental do Estado de São Paulo (CETESB). Guia Nacional de coletas e preservação de amostras. Disponível em: http://www.cetesb.sp.gov.br/userfiles/file/laboratorios/publicacoes/guia-nacional-coleta2012.pdf . Acesso em: 08. Set. 2013

CETESB. Qualidade das águas subterrâneas no Estado de São Paulo. Cetesb, São Paulo 242f., 2013. 
CETESB. Qualidade das águas superficiais no Estado de São Paulo. Cetesb, São Paulo, 520f., 2014.

CLODE, S. A. Assessment of in vivo assays for endocrine disruption. Best Practice \& Research Clinical Endocrinology \& Metabolism, v. 20, p. 35-43, 2006.

COLBORN, T.; VOM SAAL, F. S. ; SOTO, A. M. Developmental effects of endocrinedisrupting chemicals in wildlife and humans. Environmental Health Perspectives, v. 101, n. 5, p. 378-384, 1993.

COLEMAN, H. M. et al. Fate and analysis of endocrine disrupting chemicals in some sewage treatment plants in Australia. Water Science and Technology, v. 58, n. 11, p. 2187-2194, 2008.

DE COSTER, S.; VAN LAREBEKE, N. Endocrine-disrupting chemicals: Associated disorders and mechanisms of action. Journal of Environmental and Public Health, v. 2012, p.1-52.

DIAS, A. C. V. et al. Analysis of estrogenic activity in environmental waters in Rio de Janeiro state (Brazil) using the yeast estrogen screen. Ecotoxicology and Environmental Safety, v. 120, p. 41-47, 2015.

D. E. Diretiva do parlamento Europeu 2000/60/CE e 2008/105/CE disponível em: http://ec.europa.eu/environment/water/waterdangersub/lib_pri_substances.htm\#prop_2011_docs. Acesso em: 29.jun.2015.

DREWES, J. et al. Removal of endocrine disrupting compounds in water reclamation processes. In: Jocelyn D.C. Hemming, Jörg E. Drewes, James J. Schauer William C. Sonzogni, Water Environmental Researche Foundation, s/1, 2006. Livro Eletrônico disponível em: http://www.watereuse.org/files/images/01HHE20T_web.pdf

ECHA, REACH. Regulamentation Evaluation Authorization of Chemicals. Disponível em : http://echa.europa.eu/pt/regulations/reach/. Acesso em: 15. set.2015.

ELDRIDGE, M. L. et al. Applied Research in Toxicology Comparison of two yeast bioluminescent assays applied to water monitoring of estrogenic activity. Applied research in Toxicology, v. 1, n. 1, p. 1-8, 2015

ESCHER, B. I. et al. Monitoring of the ecotoxicological hazard potential by polar organic micropollutants in sewage treatment plants and surface waters using a mode-of-action based test battery. Journal of environmental monitoring: JEM, v. 10, n. 5, p. 622-631, 2008.

ESCHER, B.; LEUSCH, F. Introduction to bioanalytical tools in water quality assessment. In Bioanalytical tools in water quality assessment. IWA. Londres, 253p. 2012. 
ESCHER, B. I. et al. Benchmarking organic micropollutants in wastewater, recycled water and drinking water with in vitro bioassays. Environmental Science and Technology, v. 48, p. 1940-1956, 2014.

ESPERANZA, M. et al. Determination of sex hormones and nonylphenol ethyoxylates in the aqueous matrixes of two pilot-scale municipal wastewater treatment plants. Environmental Science and Technology, v. 38, n. 11, p. 3028-3035, 2004.

ESTEBAN, S. et al. Analysis and occurrence of endocrine-disrupting compounds and estrogenic activity in the surface waters of Central Spain. Science of the Total Environment, v. 466-467, p. 939-951, 2014.

ESTRADA-ARRIAGA, E. B.; MIJAYLOVA, P. N. Influence of operational parameters (sludge retention time and hydraulic residence time) on the removal of estrogens by membrane bioreactor. Environmental science and pollution research international, v. 18, n. 7, p. 1121-8, ago. 2011.

FAGIN, D. The learning curve. Nature, v. 490, p. 462-465, 2012.

FANG, F. et al. Quantitative comparisons of in vitro assays for estrogenic activities. Environmental health perspectives, v. 108, p. 723-9, 2000.

FENSKE, M. et al. An environmentally relevant concentration of estrogen induces arrest of male gonad development in zebrafish, Danio rerio. Environmental toxicology and chemistry/SETAC, v. 24, n.5, p. 1088-98, 2005.

FISCHER, N. Cloração de água com 17ß-estradiol e utilização do teste YES para avaliação de estrogenicidade. 2013. 116 f. Dissertação (Mestrado em Engenharia Hidráulica e Saneamento), Escola de Engenharia de São Carlos - USP, São Carlos, 2013.

FISHER, J. S. Are all EDC effects mediated via steroid hormone receptors? Toxicology, v. 205, n. 1-2, p. 33-41, 2004.

FROEHNER, S. et al. Removal Capacity of Caffeine, Hormones, and Bisphenol by Aerobic and Anaerobic Sewage Treatment. Water, Air \& Soil Pollution, v. 216, p. 463-471, 2011.

FIELD, J. A.; JOHNSON, A; ROSE, J. B. What is "emerging"? Environmental Science. v. 40, 23, p. 7105-7450, 2006.

FUKUSHIMA, T. et al. Toxicity assessment of chlorinated wastewater effluents by using transcriptome-based bioassay and Fourier transform mass spectrometry (FT-MS) analysis. Water Research, v. 52, p. 73-82, 2014. 
FUTRAN FUHRMAN, V.; TAL, A.; ARNON, S. Why endocrine disrupting chemicals (EDCs) challenge traditional risk assessment and how to respond. Journal of Hazardous Materials, v. 286, p. 589-611, 2015.

GAULKE, L. S. et al. 17 $\alpha$-ethinylestradiol transformation via abiotic nitration in the presence of ammonia oxidizing bacteria. Environmental science \& technology, v. 42, p. 7622-27, 2008 .

GAULKE, L. S. et al. Estrogen biodegradation kinetics and estrogenic activity reduction for two biological wastewater treatment methods. Environmental science \& technology, v. 43, n. 18, p. 7111-6, 2009.

GAVRILESCU, M. et al. Emerging pollutants in the environment: present and future challenges in biomonitoring, ecological risks and bioremediation. New Biotechnology, v. 32, n. 1, p. 147-156, 2014.

GHISELLI, G., Avaliação da qualidade das águas destinadas ao abastecimento público na região de Campinas: Ocorrência e determinação dos Interferentes Endócrinos (IEs) e Produtos Farmacêuticos e de Higiene Pessoal (PFHP). 2006. Tese ( Doutorado em química). Instituto de Química.UNICAMP. 27, Campinas, 2006.

GHISELLI, G., JARDIM W. F. Interferentes Endócrinos no ambiente. Química Nova. v. 30, no. 3, p. 695-706, 2007.

GORGA, M. et al. Analysis of endocrine disrupters and related compounds in sediments and sewage sludge using on-line turbulent flow chromatography-liquid chromatography-tandem mass spectrometry. Journal of Chromatography A, v. 1352, p. 29-37, 2014.

GRASSI, M.; RIZZO, L.; FARINA, A. Endocrine disruptors compounds, pharmaceuticals and personal care products in urban wastewater: implications for agricultural reuse and their removal by adsorption process. Environmental science and pollution research international, $n^{\circ} 6$, v. 20, p. 3616-28, 2013.

GUILLETTE, L. J.; IGUCHI, T. Ecology. Life in a contaminated world. Science, v. 337, n. 6102, p. 1614-5, 2012.

HAO, R. et al. Structure-biodegradability relationship of nonylphenol isomers during biological wastewater treatment process. Chemosphere, v. 75, n. 8, p. 987-94, 2009.

HUANG, C. H.; SEDLAK, D. L. Analysis of estrogenic hormones in municipal wastewater effluent and surface water using enzyme-linked immunosorbent assay and gas chromatography/tandem mass spectrometry. Environmental toxicology and chemistry/SETAC, v. 20, n. 1, p. 133-139, 2001. 
HUCK, C. W.; BONN, G. K. Recent developments in polymer - based sorbents for solidphase extraction. Journal of Chromatography A, v. 885, p. 51-72, 2000.

IFELEBUEGU, A. O. The fate and behavior of selected endocrine disrupting chemicals in full scale wastewater and sludge treatment unit processes. Internation Journal of Environmental Science \& Technology, v. 8, n. 2, p. 245-254, 2011.

JARDIM, W. F. et al. An integrated approach to evaluate emerging contaminants in drinking water. Separation and Purification Technology, v. 84, p. 3-8, 2012.

JAROSOVA, B. et al. What level of estrogenic activity determined by in vitro assays in municipal waters can be considered as safe? Environmental International, v.64, p. 98-109, 2014.

JIANG, J. Q.; ZHOU, Z.; SHARMA, V. K. Occurrence, transportation, monitoring and treatment of emerging micro-pollutants in waste water - A review from global views. Microchemical Journal, v.110, p. 292-300, 2013.

JOHNSON, A.C.; SUMPTER, J. Removal of endocrine-disrupting chemicals in activated sludge treatment works. Environmental science \& technology, v. 35, p. 4697-470, 2001.

JOHNSON, A. C. et al. Comparing steroid estrogen, and nonylphenol content across a range of European sewage plants with different treatment and management practices. Water Research, v. 39, p. 47-58, 2005.

JOSS, A. et al. Removal of estrogens in municipal wastewater treatment under aerobic and anaerobic conditions: consequences for plant optimization. Environmental science \& Technology, v. 38, n.11, p. 30 47-55, 2004.

KHUNJAR, W. O. et al. Elucidating the relative roles of ammonia oxidizing and heterotrophic bacteria during biotransformation of $17 \alpha$-ethinylestradiol and trimethoprim. Environmental science \& Technology, v. 45, n. 8, p. 3605-3612, 2011.

KIDD, K. A. et al. "Human and wildlife exposures to EDCs" In Bergaman, A. et al., State of the science of endocrine disrupting chemicals - 2012.Genebra. UNEP/WHO. 2013. Cap.3, p.189-250.

KIRK, L. A. et al. Changes in estrogenic and androgenic activities at different stages of treatment in wastewater treatment works. Environmental toxicology and chemistriy/ SETAC, v. 21, n. 5, p. 972-979, 2002.

KOOKANA, R.; WILLIAMS, M.; WALLER, N. Endocrine-disrupting chemicals in the Australian environment Background and current research in Australia. Discussion Paper. 
Australian Government - Land \& Water Australia. maio. 2007. Disponível em: http://www.lwa.gov.au. Acesso em 20.mar.2014.

LAMB, J. C. et al. Critical comments on the WHO-UNEP State of the Science of Endocrine Disrupting Chemicals - 2012. Regulatory toxicology and pharmacology: RTP, v. 69, n. 1, p. 22-40, 13 fev. 2014.

LARA, F. J. et al. Determination of sulfonamide residues in water samples by in-line solidphase extraction-capillary electrophoresis. Journal of chromatography. A, v. 1216, n. 15, p. 3372-9, 2009.

LAURENSON, J. P. et al. Ethinyl estradiol and other human pharmaceutical estrogens in the aquatic environment: a review of recent risk assessment data. The AAPS journal, v. 16, n. 2, p. 299-310, 2014.

LEGLER, J. et al. Development of a stably transfected estrogen receptor-mediated luciferase reporter gene assay in the human T47D breast cancer cell line. Toxicological Sciences, v. 48, n. 1, p. 55-66, 1999.

LESKINEN, P. et al. Bioluminescent yeast assays for detecting estrogenic and androgenic activity in different matrices. Chemosphere, v. 61, n. 2, p. 259-266, 2005.

LEUSCH, F. D. L. et al. Bioassay-derived androgenic and estrogenic activity in municipal sewage in Australia and New Zealand. Ecotoxicology and Environmental Safety, v. 65, n. 3, p. 403-411, 2006.

LEUSCH, F. D. L. et al. Comparison of five in vitro bioassays to measure estrogenic activity in environmental waters. Environmental Science and Technology, v. 44, n. 10, p. 3853$3860,2010$.

LEUSCH, F. D. et al. Assessment of wastewater and recycled water quality: a comparison of lines of evidence from in vitro, in vivo and chemical analyses. Water Research, v. 50, p. 420-31, 2014.

LISKA, I. Fifty years of solid-phase extraction in water analysis - historical development and overview. Journal of chromatography, v. 885, p. 3-13, 2000.

LINTELMANN, J. et al. IUPAC Technical Report: Endocrine disruptors in the environment. Pure Appl. Chem., 5, v. 75, p. 631-681, 2003.

LIU, Z. et al. Removal of natural estrogen and their conjugates in municipal wastewater treatment plants: a critical review. Environmental science \& Technology, v. 49, p. 52885300, 2015. 
LIU, Z. H.; KANJO, Y.; MIZUTANI, S. Removal mechanisms for endocrine disrupting compounds (EDCs) in wastewater treatment - physical means, biodegradation, and chemical advanced oxidation: A review. Science of the Total Environment, v. 407, n. 2, p. 731-748, 2009.

LOPES, L. G. et al. Estrogênios em águas naturais e tratadas da região de Jaboticabal - São Paulo. Química Nova. v. 33, n. 3, p. 639-643, 2010.

LUO, Y. et al. A review on the occurrence of micropollutants in the aquatic environment and their fate and removal during wastewater treatment. The Science of the total environment, v. 473-474, p. 619-41, 2014.

LUST, M. J. et al. Biodegradation kinetics of 17 $\alpha$-ethinylestradiol in activated sludge treatment processes. Environmental Engineering Science, v. 32, n. 7, p. 637-646, 2015.

MARGOT, J. et al. Treatment of micropollutants in municipal wastewater: ozone or powdered activated carbon? The Science of the total environment, v. 461-462, p. 480-98, 2013.

MARTIN, O. V et al. Human health and endocrine disruption: a simple multicriteria framework for the qualitative assessment of end point specific risks in a context of scientific uncertainty. Toxicological sciences: an official journal of the Society of Toxicology, v. 98, n. 2, p. 332-47, ago. 2007

METCALFE, C. D. et al. Estrogenic potency of chemicals detected in sewage treatment plant effluents as determined by in vivo assays with Japanese medaka (Oryzias latipes).

Environmental toxicology and chemistry/SETAC, n. 2, v. 20, p. 297-308, 2001.

METCALFE, C. D. et al. A multi-assay screening approach for assessment of endocrineactive contaminants in wastewater effluent samples. Science of the Total Environment, v. 454-455, p. 132-140, 2013.

MICHAEL, I. et al. Dissolved effluent organic matter: Characteristics and potential implications in wastewater treatment and reuse applications. Water Research, v. 77, p. 213 $248,2015$.

MONTAGNER, C. C. R. Ocorrência de interferentes endócrinos e produtos farmacêuticos nas águas superficiais da bacia do rio Atibaia. 2007. 126 f. (Dissertação Mestrado em química), Instituto de química, UNICAMP, Campinas, 2007.

MONTAGNER, C. C., R.; JARDIM, W. F. Spatial and Seasonal Variations of Pharmaceuticals and Endocrine Disruptors in the Atibaia River, Journal of the Brazilian Chemical Society, v. 22, p. 1452-1462, 2011. 
MOREIRA, D. S. et al. Occurrence of endocrine disrupting compounds in water sources of Belo Horizonte Metropolitan Area, Brazil. Environmental Technology, v. 30, n. 10, p. 1041-1049, 2009.

MMA Ministério do Meio Ambiente. Disponível em: <www.mma.gov.br/segurancaquímica/convencao-de-estocolmo>. Acesso em: 12 set. 2012

MULLER, M. et al. Chemical and biological analysis of endocrine-disrupting hormones and estrogenic activity in an advanced sewage treatment plant. Environmental toxicology an chemistry/SETAC, v. 27, n. 8, p. 1649-1658, 2008.

OGUNLAJA, O. O.; PARKER, W. J. Assessment of the removal of estrogenicity in biological nutrient removal wastewater treatment processes. Science of The Total Environment, v. 514, p. 202-210, 2015.

OHTA, R. et al. Ovariectomized mouse uterotrophic assay of 36 chemicals. The Journal of Toxicological Sciences. v. 37, n.5, p. 879-889, 2012.

ONDA, K. et al. Evaluation of estrogen-like activity on sewage treatment processes using recombinant yeast. Water science and technology: a journal of the Internacional Association on Water Pollution Research, v.46, n.11-12, p. 367-373, 2002.

PANTER, G. H. ; THOMPSON, R.; SUMPTER, J. P. Adverse reproductive effects in male fathead minnows (Pimephales promelas) exposed to environmentally relevant concentrations of the natural oestrogens, oestradiol and oestrone. Aquatic Toxicology, n. 4, v. 42, p. 243 $253,1998$.

PESSOA, G. P. et al. Occurrence and removal of estrogens in Brazilian wastewater treatment plants. Science of the Total Environment, v. 490, p. 288-295, 2014.

PETRIE, B. et al. Assessing potential modifications to the activated sludge process to improve simultaneous removal of a diverse range of micropollutants. Water Research, v. 62, p. 180$192,2014$.

POOLE, C. F. New trends in solid-phase extraction. TrAC - Trends in Analytical Chemistry, v. 22, n. 6, p. 362-373, 2003.

PRASSE, C. et al. Spoilt for choice: A critical review on the chemical and biological assessment of current wastewater treatment technologies. Water Research. v. 87, p-237-270, 2015 .

PURDOM C.E. et al. Estrogenic effects of effluents from sewage treatment works. Chemical Ecology. v. 8, p. 227-85, 1994. 
QUEIROZ, F. B. et al. Occurrence of pharmaceuticals and endocrine disruptors in raw sewage and their behavior in UASB reactors operated at different hydraulic retention times. Water Science \& Technology, v. 6612, p. 2562-2569. 2012

RAIMUNDO, C. C. M. Contaminantes emergentes em água tratada e seus mananciais: sazonalidade, remoção e atividade estrogênica, 2011. 203 f. Tese (doutorado em química), Instituto de Química, UNICAMP, Campinas, 2011.

REDDY, S.; BROWNAWELL, B. J. Analysis of estrogens in sediment from a sewageimpacted urban estuary using high-performance liquid chromatography/time-of-flight mass spectrometry. Environmental toxicology and chemistry / SETAC, 5, v. 24, p. 1041-7, 2005.

RODA, A. et al. Analytical approach for monitoring endocrine-disrupting compounds in urban waste water treatment plants. Analytical and bioanalytical chemistry, v. 385, n. 4, p. 742-52, 2006.

RUAN, T. et al. Evaluation of the in vitro estrogenicity of emerging bisphenol analogs and theis respective estrogenic contributions in municipal sewage sludge in China. Chemosphere, v. 124, p.150-155, 2015.

ROTROFF, D. M. et al. Predictive endocrine testing in the 21 st century using in vitro assays of estrogen receptor signaling responses. Environmental Science and Technology, v. 48, n. 15, p. 8706-8716, 2014.

ROUTLEDGE, E.; SUMPTER, J. P. Estrogenic activity of surfactants and some of their degradation products assessed using a recombinant yeast screen. Environmental Toxicology and Chemistry, n. 3, v.15, p.241-248, 1996.

SABESP. s/I, s/d, Disponível em: < http://www.sabesp.com.br>. Acessado em 14.01.2014.

SALSTE, L. et al. Determination of estrogens and estrogenic activity in wastewater effluent by chemical analysis and the bioluminescent yeast assay. Science of the Total Environment, v. 378, p. 343-351, 2007.

SANSEVERINO, J. et al. Use of Saccharomyces cerevisiae BLYES expressing bacterial bioluminescence for rapid, sensitive detection of estrogenic compounds. Applied and environmental microbiology, n.8, v.71, p. 4455-4460, 2005.

SANSEVERINO, J. et al. Screening of potentially hormonally active chemicals using bioluminescent yeast bioreporters. Toxicological sciences: an official journal of the Society of Toxicology, 1, v. 107, p.122-34, 2009.

SCHWARZENBACH, R. et al. Institute Global Water Pollution and Human Health. Annual Review of Environment and Resources, n. 1, v. 35, p.109-136, 2010. 
SHEN, J. et al. EADB: An estrogenic activity database for assessing potential endocrine activity. Toxicological sciences: an official journal of the Society of Toxicology, v. 135, n. 2, p. 277-91, 2013.

SODRÉ, F. F. et al. Ocorrência de interferentes endócrinos e produtos farmacêuticos em águas superficiais da região de Campinas (SP, Brasil). J. Braz. Soc. Ecotoxicol., v. 2, n. 2 , p.187-196, 2007.

SODRÉ, F. F. et al. Assessing selected estrogens and xenoestrogens in Brazilian surface waters by liquid chromatography-tandem mass spectrometry. Microchemical Journal, v. 96, n. 1, p. 92-98, 2010.

SOLANO, M. L. M. et al. Potential endocrine disruptor activity of drinking water samples. Endocrine Disruptors, v.3, n.1, p.9833841-12, 2015.

SONG, W.; WANG, Z.; LIAN, C. Assessment of in vivo estrogenic response and identification of environmental estrogens in influent and effluent from a sewage treatment plant. Bulletin of environmental contamination and toxicology, v. 91, n. 3, p. 324-9, set. 2013.

SOTO, A. M. et al. p-nonyl-phenol: an estrogenic xenobiotic released from "modified" polystyrene. Environmental health perspectives, n. 6, v. 92, p.167-73, 1991.

SOTO, A. M. et al. Strengths and weaknesses of in vitro assays for estrogenic and androgenic activity. Best Practice \& Research Clinical Endocrinology \& Metabolism, n. 1, v. 20, p. 15-33, 2006.

SILVA, C. P.; OTERO, M.; ESTEVES, V. Processes for the elimination of estrogenic steroid hormones from water: a review. Environmental pollution, v. 165, p. 38-58, 2012.

SOUZA, N. C. Avaliação de Micropoluentes Emergentes em Esgotos e Águas

Superficiais. 2011, 166f. Tese (Doutorado em Engenharia Civil), Universidade Federal do Ceará, Fortaleza, 2011.

SPERLING, M. VON. Wastewater Characteristics, Treatment and Disposal. Londres, IWA, 2007.

SUAREZ, S.; LEMA, J. M.; OMIL, F. Removal of pharmaceutical and personal care products (PPCPs) under nitrifying and denitrifying conditions. Water Research, v. 44, n.1, p. 32143224, 2010.

SUI, Q. et al. Seasonal variation in the occurrence and removal of pharmaceuticals and personal care products in different biological wastewater treatment processes. Environmental science \& technology, v. 45, n. 8, p. 3341-8, 2011. 
SVENSON, A.; ALLARD, A. S.; EK, M. Removal of estrogenicity in Swedish municipal sewage treatment plants. Water research, v. 37, n.18, p. 4433-4443, 2003.

TAN, D. T.; ARNOLD, W. A.; NOVAK, P. J. Effects of estrone and organic carbon exposure on the transformation of estrone. Environmental Science Water Research Technology, v.1, n. 4, p. 457-464, 2015.

TERNES, T. A et al. Behavior and occurrence of estrogens in municipal sewage treatment plants - I. Investigations in Germany, Canada and Brazil. The Science of the total environment, v. 225, n. 1-2, p. 81-90, 12 jan. 1999a.

TERNES, T. A. ; KRECKER P.: MUELLER J. Behaviour and occurrence of estrogens in municipal sewage treatment plants - II. Aerobic batch experiments with activated sludge. The Science of the total environment, v. 225, p. 91-99, 1999b.

TERNES, T. A.; JOSS, A. Human, pharmaceuticals, hormones and fragrances: the challenges of micropolutants in urban water management, IWA, 468 f., Londres, 2008.

TERNES, T.; JOSS, A.; OEHLMANN, J. Occurrence, fate, removal and assessment of emerging contaminants in water in the water cycle (from wastewater to drinking water). Water Research,v. 72, p. 1-2, 2015.

THUNDIYIL, J. G.; SOLOMON, G. M.; MILLER, M. D. Transgenerational exposures: persistent chemical pollutants in the environment and breast milk. Pediatric clinics of North America, v. 54, n. 1, p. 81-101, 2007.

UNESCO, Water in a changing world development. Paris - Nova Iorque.

UNESCO/Berghahn Books. The United Nations World Water Report, no. 3, 2009.

VADER, J. S. et al. Degradation of ethinylestradiol by nitrifying activated sludge.

Chemosphere, v. 41, n. 8, p. 1239-1243, 2000.

VAN DEN BELT, K.; VERHEYEN, R.; WITTERS, H. Comparison of vitellogenin responses in zebrafish and rainbow trout following exposure to environmental estrogens. Ecotoxicology and Environmental Safety, v. 56, n. 2, p. 271-281, 2003.

VANDENBERG, L. N. et al. Hormones and endocrine-disrupting chemicals: low-dose effects and nonmonotonic dose responses. Endocrine Reviews, v. 33, n. 3, p. 378-455, 2012.

VERMEIRSSEN, E. L. M.; SUTER, M. J. F.; BURKHARDT-HOLM, P. Estrogenicity patterns in the Swiss midland river Lützelmurg in relation to treated domestic sewage effluent discharges and hydrology. Environmental toxicology and chemistry / SETAC, v. 25, n. 9, p. 2413-2422, 2006. 
VOM SAAL, F.S. ; BRONSON, F. H. Utero proximity of female mouse fetuses to males: Effects on Reproductive performance during later life. Biology of reproduction. v. 19, p. 842-853, 1978.

WANG, S. et al. Towards an integrated in vitro strategy for estrogenicity testing. Journal of applied toxicology: JAT, 2013.

WANG et al. Standardized application of yeast bioluminescent reporters as endocrine disruptors screen for comparative analysis of wastewater effluents from membrane bioreactor and traditional activated sludge. Ecotoxicology. v. 24, p. 2088-99, 2015.

WATSON, K. et al. Chlorine disinfection by-products in wastewater effluent: Bioassay-based assessment of toxicological impact. Water Research, v. 46, n. 18, p. 6069-6083, 2012.

ZHOU, H. et al. Behaviour of selected endocrine-disrupting chemicals in three sewage treatment plants of Beijing, China. Environmental Monitoring and Assessment, n. 161, v. 1-4, p. 107-121, 2010.

ZHOU, H. et al. Fate and removal of selected endocrine-disrupting compounds in sewage using activated sludge treatment. Water and Environment Journal, v. 26, n. 4, p. 435-444, 2012.

YIN, G.; KOOKANA, R. S.; RU, Y. J. Occurrence and fate of hormone steroids in the environment. Environment international, n. 6, v. 28, p. 545-51, 2002.

YOST, E. E. et al. Bridging the gap from screening assays to estrogenic effects in fish: potential roles of multiple estrogen receptor subtypes. Environmental Science \& Technology. v. 48, p. 5211-5219, 2014. 
Apêndice- Descrição das amostras coletadas nas ETEs 1 e 2. Foram feitas coletas simples e em ausência de chuvas nas 24 horas que antecederam a coleta.

\begin{tabular}{|c|c|c|c|c|c|c|c|}
\hline \multicolumn{8}{|c|}{ Dados das coletas realizadas } \\
\hline & Local & Amostra & Dia & Hora & $\begin{array}{l}\text { Temper } \\
\left({ }^{\circ} \mathrm{C}\right) \\
\mathrm{Ar}\end{array}$ & $\begin{array}{l}\text { tura } \\
\text { água }\end{array}$ & $\mathrm{pH}$ \\
\hline \multirow{6}{*}{$\begin{array}{c}\text { Ensaio } \\
\text { I }\end{array}$} & $\begin{array}{l}\text { Entrada } \\
\text { ETE 1 }\end{array}$ & $\begin{array}{l}\text { Esgoto } \\
\text { bruto }\end{array}$ & 10.03 .14 & $15: 26$ & 36,0 & 28,5 & 6,86 \\
\hline & $\begin{array}{l}\text { Saída } 1 \\
\text { ETE } 1\end{array}$ & $\begin{array}{l}\text { Esgoto } \\
\text { tratado }\end{array}$ & 10.03 .14 & $15: 13$ & 36,7 & 29,8 & 6,52 \\
\hline & $\begin{array}{l}\text { Saída } 2 \\
\text { ETE1 }\end{array}$ & $\begin{array}{l}\text { Água de } \\
\text { reuso }\end{array}$ & 10.03 .14 & $15: 02$ & 36,4 & 30,1 & 6,58 \\
\hline & $\begin{array}{l}\text { Entrada } \\
\text { ETE 2 }\end{array}$ & $\begin{array}{l}\text { Esgoto } \\
\text { bruto }\end{array}$ & 10.03 .14 & 11:05 & 31,3 & 26,9 & 7,10 \\
\hline & $\begin{array}{l}\text { Saída } 1 \\
\text { ETE } 2\end{array}$ & $\begin{array}{l}\text { Esgoto } \\
\text { tratado }\end{array}$ & 10.03 .14 & $10: 52$ & 30,9 & 27,2 & 6,42 \\
\hline & $\begin{array}{l}\text { Saída } 2 \\
\text { ETE } 2\end{array}$ & $\begin{array}{l}\text { Água de } \\
\text { reuso }\end{array}$ & 10.03 .14 & $10: 43$ & 28,9 & 27,6 & 6,86 \\
\hline \multirow{6}{*}{$\begin{array}{c}\text { Ensaio } \\
\text { II }\end{array}$} & $\begin{array}{l}\text { Entrada } \\
\text { ETE 1 }\end{array}$ & $\begin{array}{l}\text { Esgoto } \\
\text { bruto }\end{array}$ & 23.04.14 & $16: 00$ & 22,3 & 25,2 & 6,81 \\
\hline & $\begin{array}{l}\text { Saída } 1 \\
\text { ETE } 1\end{array}$ & $\begin{array}{l}\text { Esgoto } \\
\text { tratado }\end{array}$ & 23.04 .14 & $15: 46$ & 22,3 & 26,1 & 6,78 \\
\hline & $\begin{array}{l}\text { Saída } 2 \\
\text { ETE1 }\end{array}$ & $\begin{array}{l}\text { Água de } \\
\text { reuso }\end{array}$ & 23.04 .14 & $15: 57$ & 22,3 & 26,0 & 6,82 \\
\hline & $\begin{array}{l}\text { Entrada } \\
\text { ETE } 2 \\
\end{array}$ & $\begin{array}{l}\text { Esgoto } \\
\text { bruto }\end{array}$ & 28.04.14 & $12: 00$ & 21,2 & 23,5 & 6,98 \\
\hline & $\begin{array}{l}\text { Saída } 1 \\
\text { ETE 2 }\end{array}$ & $\begin{array}{l}\text { Esgoto } \\
\text { tratado }\end{array}$ & 28.04 .14 & $12: 20$ & 21,8 & 24,1 & 6,43 \\
\hline & $\begin{array}{l}\text { Saída } 2 \\
\text { ETE } 2\end{array}$ & $\begin{array}{l}\text { Água de } \\
\text { reuso }\end{array}$ & 28.04 .14 & $12: 30$ & 22,1 & 24,2 & 6,36 \\
\hline \multirow{9}{*}{$\begin{array}{c}\text { Ensaio } \\
\text { III }\end{array}$} & $\begin{array}{l}\text { Entrada } \\
\text { ETE 1 }\end{array}$ & $\begin{array}{l}\text { Esgoto } \\
\text { bruto }\end{array}$ & 19.05.14 & $13: 30$ & 24,1 & 25,2 & 7,31 \\
\hline & $\begin{array}{l}\text { Saída } 1 \\
\text { ETE } 1\end{array}$ & $\begin{array}{l}\text { Esgoto } \\
\text { tratado }\end{array}$ & 19.05 .14 & $13: 40$ & 24,1 & 25,9 & 6,90 \\
\hline & $\begin{array}{l}\text { Saída } 2 \\
\text { ETE1 }\end{array}$ & $\begin{array}{l}\text { Água de } \\
\text { reuso }\end{array}$ & 19.05 .14 & $13: 50$ & 24,2 & 25,3 & 7,17 \\
\hline & $\begin{array}{l}\text { Entrada } \\
\text { ETE 2 }\end{array}$ & $\begin{array}{l}\text { Esgoto } \\
\text { bruto }\end{array}$ & 19.05 .14 & $10: 40$ & 20,7 & 20,2 & 7,46 \\
\hline & $\begin{array}{l}\text { Saída } 1 \\
\text { ETE } 2\end{array}$ & $\begin{array}{l}\text { Esgoto } \\
\text { tratado }\end{array}$ & 19.05 .14 & $10: 55$ & 23,4 & 24,4 & 6,61 \\
\hline & $\begin{array}{l}\text { Saída } 2 \\
\text { ETE } 2\end{array}$ & $\begin{array}{l}\text { Água de } \\
\text { reuso }\end{array}$ & 19.05 .14 & 11:05 & 24,1 & 24,9 & 6,80 \\
\hline & $\begin{array}{l}\text { Entrada } \\
\text { ETE } 2\end{array}$ & $\begin{array}{l}\text { Esgoto } \\
\text { bruto }\end{array}$ & 14.07 .14 & $11: 15$ & 19,0 & 22,0 & 7,59 \\
\hline & $\begin{array}{l}\text { Saída } 1 \\
\text { ETE } 2\end{array}$ & $\begin{array}{l}\text { Esgoto } \\
\text { tratado }\end{array}$ & 14.07 .14 & $11: 25$ & 19,2 & 22,0 & 6,45 \\
\hline & $\begin{array}{l}\text { Saída } 2 \\
\text { ETE } 2\end{array}$ & $\begin{array}{l}\text { Água de } \\
\text { reuso }\end{array}$ & 14.07 .14 & $11: 35$ & 19,4 & 22,3 & 6,73 \\
\hline
\end{tabular}




\begin{tabular}{|c|l|l|c|c|cc|c|}
\hline $\begin{array}{c}\text { Ensaio } \\
\text { IV }\end{array}$ & $\begin{array}{l}\text { Entrada } \\
\text { ETE 1 }\end{array}$ & $\begin{array}{l}\text { Esgoto } \\
\text { bruto }\end{array}$ & 08.09 .14 & $11: 09$ & 23,2 & 24,9 & 7,57 \\
\cline { 2 - 8 } & $\begin{array}{l}\text { Saída 1 } \\
\text { ETE 1 }\end{array}$ & $\begin{array}{l}\text { Esgoto } \\
\text { tratado }\end{array}$ & 08.09 .14 & $11: 20$ & 25,3 & 27,0 & 6,98 \\
\cline { 2 - 8 } & $\begin{array}{l}\text { Saída 2 } \\
\text { ETE1 }\end{array}$ & $\begin{array}{l}\text { Água de } \\
\text { reuso }\end{array}$ & 08.09 .14 & $11: 30$ & 25,6 & 26,9 & 7,14 \\
\hline
\end{tabular}

